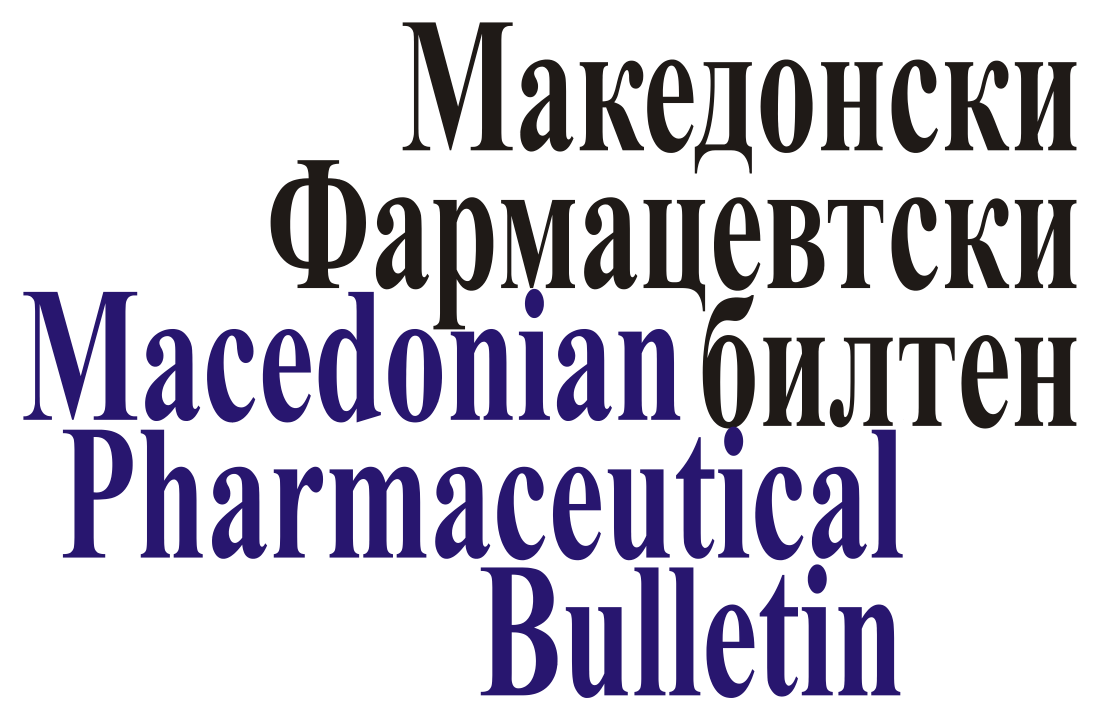

волумен 56 (1, 2) 2010 / volume 56 (1, 2) 2010

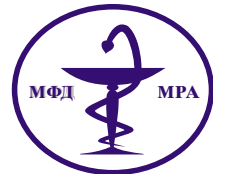

Македонско фармацевтско друштво, ул. Маршал Тито 13б/8, Скопје, Македонија Macedonian Pharnaceutical Society, Marshal Tito 13b/8, Skopje Macedonia 



\title{
The role of molecular mimicry in the etiology of Guillain Barré Syndrome
}

\author{
Aleksandra Grozdanova $^{1 *}$, Slobodan Apostolski ${ }^{2}$, Ljubica Suturkova $^{1}$ \\ ${ }^{1}$ Institute for Pharmaceutical chemistry, Faculty of Pharmacy, "St Cyril and Methodius" University, Skopje \\ ${ }^{2}$ Outpatient Neurological Clinic, Belgrade, Serbia
}

Received: May 2011; Accepted: June 2011

\begin{abstract}
Molecular mimicry between host tissue structures and microbial components has been proposed as the pathogenic mechanism for triggering of autoimmune diseases by preceding infection. Recent studies stated that molecular mimicry as the causative mechanism remains unproven for most of the human diseases. Still, in the case of the peripheral neuropathy Guillain-Barré syndrome (GBS) this hypothesis is supported by abundant experimental evidence. GBS is the most frequent cause of acute neuromuscular paralysis and in some cases occurs after infection with Campylobacter jejuni (C. jejuni). Epidemiological studies, showed that more than one third of GBS patients had antecedent $C$. jejuni infection and that only specific $C$. jejuni serotypes are associated with development of GBS. The molecular mimicry between the human gangliosides and the core oligosaccharides of bacterial lipopolysaccharides (LPSs) presumably results in production of antiganglioside cross-reactive antibodies which are likely to be a contributory factor in the induction and pathogenesis of GBS. Antiganglioside antibodies were found in the sera from patients with GBS and by sensitization of rabbits with gangliosides and $C$. jejuni LPSs animal disease models of GBS were established.

GBS as prototype of post-infection immune-mediated disease probably will provide the first verification that an autoimmune disease can be triggered by molecular mimicry.
\end{abstract}

Key words: Guillain Barré syndrome, molecular mimicry, Campylobacter jejuni, lipopolysaccharides, gangliosides

\section{The molecular mimicry hypothesis}

Molecular mimicry between host tissue structures and microbial antigens is postulated as mechanism for triggering of autoimmune disease by preceding infections. According to the mimicry hypothesis, due to the structural resemblance between microbial and some host antigens, antibodies and $\mathrm{T}$ cells that are induced by the antecedent infection and are initially directed against microbial antigens, not only destroy the invading pathogen but also attack host tissue (Albert and Inman, 1999). Molecular mimicry can be defined as presence of structurally similar epitopes in human and pathogen antigens, or in a wider sense it is sharing of antigens between hosts and microorganisms, leading

\footnotetext{
"agrozdanova@ff.ukim.edu.mk
}

to immunological process by inducing cross-reactive antibodies or $\mathrm{T}$ cells that cause the symptoms of autoimmune disease (Damian, 1964).

The molecular mimicry hypothesis was first postulated by Koch and Witebsky as a mechanism by which infectious agents trigger an immune response against autoantigens, resulting in the development of autoimmune diseases (Falkow, 1988). The initial idea that molecular mimicry might play a role in autoimmune diseases was born in the 1980s, along with the development and use of monoclonal antibody technology. It was then first noted that an antibody might cross-react with both human and viral antigens. A number of similar cross-reactivity between microbial structures and host self determinants were subsequently recorded and molecular mimicry was postulated as part of pathogenesis in many diseases (Rose and Bona, 1993).

The claims whether molecular mimicry is a causative mechanism of autoimmune disease are numerous and are 
supported by abundant evidence of experiments. Still, to conclude that a disease is triggered by molecular mimicry, the following four criteria need to be satisfied:

- To establish an epidemiological association between the infectious agent and the immune - mediated disease

- To identify antibodies and/or T cells directed against the patient's target antigens

- To identify a microbial mimicry in the target antigen

- To reproduce the disease in an animal model

The concept of molecular mimicry as a possible mechanism by which infections may induce pathogenic immune responses has been linked to several diseases, such as acute rheumatic fever, multiple sclerosis and type 1 diabetes mellitus. Although there is some evidence that infectious agents play a part in the pathogenesis of a number of autoimmune diseases, it has not yet been proved that molecular mimicry is the initiating factor in any of these diseases (Rose and Mackay, 2000).

Mimicry between glutamate decarboxylase (GAD65) an enzyme present in pancreatic cells and coxsackie virus has been demonstrated (Kaufman et al., 1993). This mimicry might be responsible for cell destruction in patients with type I diabetes mellitus although convincing evidence for this in patients has yet to be found (Atkinson et al., 1992). A classic example of a disease in which molecular mimicry is postulated to be the pathogenic mechanism is rheumatic carditis with a cross-reactive immune response towards pneumococcal polysaccharides and cardiac tissue leading to rheumatic heart disease (Huber and Cunningham, 1996).

In the case of the peripheral neuropathy Guillain Barre syndrome (GBS) the hypothesis of the role of molecular mimicry in this immune-mediated disease is supported by abundant evidence of experiments. Therefore GBS is an excellent opportunity to study the relation between infections and development of neurological symptoms (Ang et al., 2004).

\section{Guillain Barré syndrome}

Guillain Barré syndrome (GBS) is the major cause of acute neuromuscular paralysis in the world since the eradication of polio, with an annual incidence of 1-2 per 100,000. It can affect all ages including children, but becomes increasingly common with age (Van Doorn et al., 2008). In the recent years much progress has been made in understanding its etiology and treatment. GBS is defined as an immune mediated disease of the peripheral nerves, involving both the myelin sheath and the axons. It is named after G. Guillain and J.A. Barre, two French neurologists who first described the syndrome in 1916 (Guillain et al., 1916). GBS as an autoimmune disorder of the peripheral nervous system is characterized by damage and dysfunction of the axon or myelin sheath of peripheral nerves which leads to weakness, usually symmetrical, evolving over a period of several days or more. Components of the immune system such as antibodies, complement, $\mathrm{T}$ cells and macrophages are present in affected nerves and are likely to be involved in the pathogenesis of the disease (Hughes et al., 1999).

\section{Clinical features of Guillain Barré Syndrome}

GBS is clinically defined by progressive weakness of two or more limbs due to neuropathy, reduced or absent reflexes, less than 50 mononuclear leucocytes per liter of cerebrospinal fluid (CSF) and absence of other known causes of acute neuropathy. Symptoms typically begin with weakness, sensory disturbance or pain, and most patients develop rapidly progressive symmetrical weakness, worse in legs than arms along with partial or complete loss of reflexes (Asbury and McKhann, 1997). Most patients experience numbness, tingling and pain and weakness classically follows an ascending temporal pattern, starting in the lower limbs and then rapidly spreading to the upper limbs and the face. Frequently, when the lower cranial nerves are affected this results in bulbar weakness, bladder dysfunction, dysphagia and respiratory difficulties (Hughes et al., 1997). Sensory loss, which usually takes the form of loss of perception, is common, along with deep aching pain in the weakened muscles (Nachamkin et al., 1998). Autonomic disturbance is common, with fluctuations in blood pressure, heart rate and bowel function. The CSF protein concentration is elevated in $80 \%$ of patients. The weakness is most severe within two to four weeks from onset, when approximately $20 \%$ of patients require artificial ventilation because of respiratory muscle weakness, $40 \%$ are bedridden, $20 \%$ can walk only with assistance, $10 \%$ can walk but not run, and $10 \%$ have only mild symptoms. The disease can be self-limited, followed by partial or complete recovery over the period of several weeks to several months (Hughes et al., 1999).

\section{Types of Guillain Barré Syndrome}

GBS represents a spectrum of clinical and pathological entities with a number of subtypes being recognized. The disease subtype is determined by the clinical manifestations and by laboratory investigations. In general GBS can be classified into two major subtypes, demyelinating neuropathies where myelin sheaths are affected and axonal neuropathies affecting motor and sensory nerves (Asbury and Cornblath, 1990). Therefore the subtypes of GBS are acute inflammatory demyelinating neuropathy (AIDP) affecting the peripheral nerve myelin, acute motor axonal neuropathy (AMAN) affecting axons, acute motor and sensory axonal neuropathy (AMSAN) and Miller Fisher syndrome (MFS) (Table 1).

AIDP is typically characterized with muscle weakness which spreads proximally and can lead to respiratory paralysis. Numbness and paraesthesia are frequently pres- 
Table 1. GBS subtypes and their relationships according to type of neuropathy

\begin{tabular}{|c|c|}
\hline \multicolumn{2}{|c|}{ Guillain Barré syndrome } \\
\hline \multicolumn{2}{|c|}{ Demyelinating } \\
\hline \multicolumn{2}{|r|}{ Acute Inflammatory Demyelinating Polyneuropathy (AIDP) } \\
\hline \multicolumn{2}{|l|}{ Axonal } \\
\hline & Acute Motor Axonal Neuropathy (AMAN) \\
\hline & Acute Motor Sensory Axonal Neuropathy (AMSAN) \\
\hline Miller Fisl & sher syndrome (MFS) \\
\hline
\end{tabular}

ent. AIDP is complicated by an autonomic neuropathy in $15 \%$ of cases, leading to life threatening dysfunction of the cardiovascular, alimentary and urinary systems. In severe cases, axonal degeneration may accompany the demyelination. The disease reaches its maximum at two weeks and recovery after a variable period of time. This can take weeks to months with up to $16 \%$ of patients suffering recurring episodes (Van der Meche and Van Doorn, 1995).

The axonal forms, AMAN and AMSAN, cause motor impairment or motor and sensory impairment respectively. In AMAN subtype motor nerves are unexcitable and axonal degeneration occurs at spinal roots and peripheral nerves with no demyelination, and little or no inflammation. In distal nerve there is a conduction block not found in AIDP (Hafer et al., 1996). The myelin sheath remains intact as the pathological process involves binding of antibodies to gangliosides located on the axolemma, resulting in infiltration of macrophages at nodes of Ranvier. AMSAN is subtype similar to AMAN, but sensory axons are also affected. It was first proposed by Griffin (Griffin et al., 1996) that AMAN and AMSAN could be part of a spectrum of a subtype where the target epitope is axonal. It would seem that they share a common immunological profile in regard to what anti-ganglioside antibodies are found in patient sera, which differs to those common to AIDP (Hafer et al., 2000). AMSAN is usually severe, involving both motor and sensory fibers. These axonal subtypes progress more rapidly, are more severe and more often require assisted ventilation.

MFS is characterized by an acute onset of ataxia, areflexia and ophthalmoplegia (Fisher, 1956) and if the condition is accompanied by disturbance of consciousness this syndrome is defined as Bickerstaff brainstem encephalitis (BBE) (Bickerstaff, 1957). An immunohistochemical study using a monoclonal anti-GQ1b antibody indicated the dense distribution of GQ1b at paranodal myelin of cranial nerves innervating extraocular muscles (Plomp et al., 1999; Hiraga et al., 2005). The distribution of the GQ1b antigen is critical for the symptomatology of MFS. It is now recognized that these disorders share many common features, in particular the antecedent infection, the cytological dissociation of albumins and the presence of antiganglioside antibodies in certain cases. The main clinical method for distinguishing among subtypes is electrodiagnostic examination (Kuwabara et al., 2002).

The GBS subtypes show regional variations in incidence. AIDP is the most frequently subtype worldwide and constitutes $90 \%$ of cases in Europe and North America. The axonal forms (AMAN, AMSAN and MFS) constitute 5\% of cases in North America and Europe but are common (30-47\%) in China, Japan and South/Central America (McKhann et al., 1993). The most severe and life threatening complication of GBS is paralysis of the respiratory muscles which, in $25 \%$ of cases, leads to a requirement for artificial ventilation. Ten to $20 \%$ of patients suffer permanent disability, one third needs to make substantial changes to their lifestyle, while the mortality rate is 4 to $15 \%$ of cases within year. GBS patients represent a clinical challenge due to the multitude of systems affected by the disease.

\section{Treatment of Guillain Barré Syndrome}

General supportive care as monitoring the respiratory capacity and autonomic functions of GBS patients is of great importance to prevent severe complications or even death by respiratory or autonomic dysfunction (Hughes et al., 2005). Therapeutic intervention is directed at suppressing the immune reactivity or blocking the effector mechanisms. The choice of therapy in any given patient or syndrome depends on the efficacy and safety of the treatment being considered (Van der Meche and Dutch Guillain Barré study group, 1992). The main therapy is corticosteroids or immunotherapy, either plasmapheresis or intravenous immunoglobulin (IVIg) (Hughes et al., 2007). Corticosteroids are useful for short term therapy, but prolonged use is associated with potentially severe side effects including osteoporosis, fractures, avascular necrosis, coronary artery disease, and stroke, as well as hypertension, obesity and diabetes. Plasmapheresis or IVIg both are equally effective at reducing disability and mortality and reducing the number of patients requiring artificial ventilation. Several randomized controlled trials reported a beneficial effect on outcome by plasma exchange and IVIg. A recent trial demonstrated that the combination of IVIg and methylprednisolone might be superior in those patients who are in the first two weeks of disease and unable to walk unaid- 
ed and who have no contra-indication for the use of high dose steroids. However, even with immunotherapy intervention, $14 \%$ of patients still require assisted ventilation (Khan et al., 2009).

The current immunotherapy regimes are inadequate due their restricted efficacy, expense, inherent risks and lack of availability, particularly in developing countries. There is a need for a better understanding of the pathogenesis of GBS to allow development of novel targeted treatments and better prognostic indicators that will allow clinicians to predict who will require intensive treatment and who will benefit most from which intervention.

\section{Guillain Barré Syndrome and Campylobacter jejuni infection}

Approximately two-thirds of GBS patients develop this syndrome following various infection of the respiratory or gastrointestinal tract. The organisms most commonly associated with GBS are Campylobacter jejuni (4-66\%), Cytomegalovirus (5-15\%), Epstein-Barr virus (2-10\%), Mycoplasma pneumonia (1-5\%) (Jacobs et al., 1998). In rare cases of GBS, infective endocarditis, rubella virus infection, Haemophlus influenzae and Legionnella infection may be associated (Hadden et al., 2001; Kaida et al., 2004). Vaccinations, including flu vaccine, immunization against group A streptococcus, rabies, and swine flu, may also trigger GBS (Yuki and Hirata 1998; Nachamkin et al., 2008). All of these pathogens have carbohydrate antigens in common with peripheral nerve tissue. Frequently most identified triggering agent of GBS is Campylobacter jejuni (C. jejuni), a spiral-shaped Gram-negative bacterium which is the main cause of acute gastroenteritis and bacterial diarrhea worldwide. Several reports described cases in which C. jejuni infection has been the preceding infection in GBS and showed strong epidemiological association between $C$. jejuni and GBS (Rees et al., 1995). Few of those reports have concluded that $C$. jejuni plays a major role in the onset of disease and that GBS associated with C. jejuni infection can be in more severe form and that it is more likely to be of the AMSAN variant (Kuwabara et al., 2004).

Recent data, present that $25-33 \%$ of GBS patients had conferred antecedent $C$. jejuni infection. There are more than 70 serotypes of $C$. jejuni but only few C. jejuni serotypes are associated with development of GBS (Kuroki et al., 1993). Biochemical and serological studies showed that GBS associated C. jejuni serotypes bear lipopolysaccharide (LPS) structures that mimic human gangliosides (Yuki et al., 1993). Gangliosides as components of the neuronal cell surface and myelin sheath are considered one of the possible target antigens for an autoimmune attack since serum anti-ganglioside antibodies are present in the acute phase of GBS subsequent to $C$. jejuni infection. Ganglioside-like structures are found more frequently in neuropathy associated $C$. jejuni strains than in strains isolated from patients with diarrhea (Ho et al., 1999; Sheikh et al., 1998).
Result of this molecular mimicry between the core oligosaccharides of bacterial LPS and carbohydrate moiety of the human gangliosides is induction of cross-reactive antibodies which are likely to be a contributory factor in the induction and pathogenesis of GBS (Fig. 1).

GM1 ganglioside

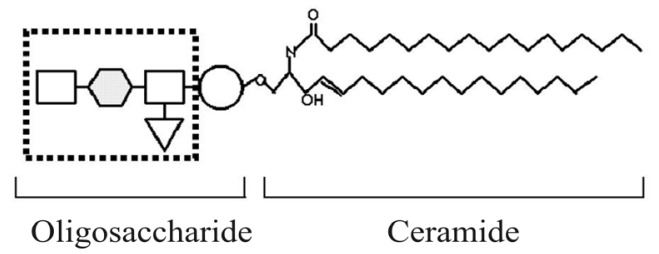

\section{Lipopolysaccharide in C. jejuni}

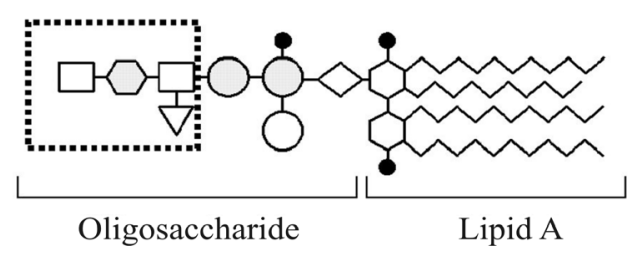

Fig. 1. Carbohydrate mimicry between GM1 ganglioside and $C$. jejuni lipopolysaccharide. Adapted from Ang C.W. et al., 2004

C. jejuni serotype commonly associated with GBS is serotype O:19, a serotype rarely isolated from uncomplicated gastroenteritis patients. Other $C$. jejuni serotypes identified in association with GBS include O:2, O:2/44, O:4/59, O:15, O:18, O:21, O:24, O:30, O:37 and O:53 (Aspinall et al., 1993).

In our previous work we have showed that some of the C. jejuni serotypes isolated from patient with enteritis and with no neurological symptoms also bear ganglioside like epitopes in their LPS molecules (Grozdanova et al., 2011). In our collection of $21 C$. jejuni isolates from enteritis patient seven different serotypes of $C$. jejuni (O:27; O:6/O:7; O:38; O:3; O:1/O:44; O:19; O:37) were detected using Penner system. Unexpected one serotype from this group was detected as O:19, a serotype rarely isolated from enteritis patient and in close association with GBS. Binding studies with cholera toxin B subunit used as GM1 ligand and peanut agglutinin as marker for Gal $\beta 1-3 \mathrm{GalNAc}$ structures showed presence of ganglioside-like epitopes in $C$. jejuni strains O:37, O:19 and O:27. Immune-reactivity with sera from patient with GBS with confirmed previous exposure to C. jejuni and with high titre of anti-ganglioside antibodies showed that the same three LPSs from $C$. jejuni serotypes O:37, O:19 and O:27 are bearing cross-reactive epitopes in their LPSs structures. These results are in correlation with studies from other research groups, that LPSs from certain C. jejuni serotypes are bearing cross-reactive gangliosidelike epitopes which might be involved in the induction of GBS after C. jejuni infection (Ang et al., 2004). 


\section{Antiganglioside antibodies in Guillain Barré Syndrome}

Epidemiological studies showed that acute-phase sera of patients with $C$. jejuni associated GBS contain high titers of antibodies directed to various gangliosides, predominantly to GM1 in approximately $30 \%$, and also antibody against asialoGM1, GD1b, GT1a, GM3, GD1a, and GT1b. Gangliosides are large and heterogeneous family of membrane glycolipids, highly expressed in nervous tissue, representing nearly $10 \%$ of the total lipid content of the peripheral and the central nervous systems (Ho et al., 1999). They are composed of a ceramide tail inserted in the lipid bilayer and a highly variable oligosaccharide moiety protruding externally, with one or more sialic acid(s). The number of sialic acid residues in a ganglioside is used to classify the different species, with one sialic acid designated by $\mathrm{M}$ (monosialo), two by $\mathrm{D}$ (disialo), giving rise to names such as GM1 (monosialo tetrahexosyl ganglioside), GM2 and GM3. Ganglioside localization studies have shown that GM1 and GM1-like epitopes are concentrated at the nodal regions and the paranodal myelin loops and in the motor nerve myelin of the human sensory and motor nerves (Sheikh et al., 1998). The suggestion that antiganglioside antibodies may play an important role in the pathogenesis of GBS came following the reports of high titers of antiganglioside antibodies in patients with a motor neuron disease. In 1988, Ilyas et al reported antiganglioside antibodies in 5 out of 26 GBS patients and the clinical improvement coincided with a reduction in the antibody titers (Ilyas et al., 1988). The presence of IgG anti-GM1 antibodies was later demonstrated in two patients who had AMAN associated with C. jejuni enteritis. Since then, there have been several other gangliosides detected that appear to be target pathogenic antigens in the development of AMAN. These include GD1a, GalNAc-GD1a and GM1b (Yuki et al., 1990). Several reports of patients developing GBS after ganglioside administration have also been reported, and IgG anti-GM1 and GDla antibodies were identified in some of the patients (Illa et al., 1995). Autoantibodies are considered to be the pathogenic components which trigger GBS because plasma exchange is proven to be an effective treatment in GBS (Hirota et al., 1997).

Following the strong epidemiological data that linked GBS to previous $C$. jejuni infection, scientists were eager to elucidate the postulated association. Yuki and coworkers in 1993 reported that gas-liquid chromatography-mass spectrometric analysis of acute-phase sera from patients with GBS after $C$. jejuni infection has shown that the purified LPS contained Gal, GalNAc, and NeuAc, which are sugar components of GM1 ganglioside (Yuki et al., 1993). The following year they further isolated $C$. jejuni from 2 patients with Miller Fisher syndrome subsequent to enteritis and then extracted and separated crude LPS fractions from the bacteria by thin-layer chromatography. Using monoclonal antibodies to GQ1b ganglioside they showed that both LPS fractions reacted to the anti-GQ1b antiganglioside antibodies, indicating that the LPS bear the GQ1b epitope (Yuki et al., 2004). These were the first evidence of molecular mimicry between neural tissue components and the often associated antecedent infectious agents of AIDP and MFS. A further work illustrated that anti-GM1 and anti-GDla antibodies reacted with the LPSs of serotypes $C$. jejuni O:1, O:4 and O:19. In 1994, Aspinall and Penner elucidated the structure of the core oligosaccharide regions of $C$. jejuni strains O:4, and O:19 and concluded that they mimic human gangliosides in structure (Aspinall et al., 1994). Later on, other reports of the immunological mimicry of $C$. jejuni were published with focus into GBS associated C. jejuni serotypes (Wirguin et al., 1997).

In one of the study conducted by our research group we have determine the frequency of antecedent infection with C. jejuni in the population of our GBS patients, the association with anti-GM1 antibodies and the distribution of these antibodies within clinical forms of the disease. The diagnosis of GBS has been established in 17 patients according to clinical, electrophysiological and laboratory criteria. In relation to the clinical form and disability score two patients were ambulatory, five were ambulatory with support, seven were bedridden and two patients needed respirator. Five (29\%) patients had pure motor, while 12 (71\%) had sensor and motor GBS. Electromyoneurography showed primary axonal, predominantly motor neuropathy in $6(35 \%)$ and demyelinating sensor and motor neuropathy in $11(65 \%)$ patients. The CSF protein content ranged from 0.47 to 3.88 $\mathrm{g} / \mathrm{L}$. Anti-C. jejuni antibodies were found in $8(73 \%)$ out of 11 patients with demyelinating GBS and in $4(66.6 \%)$ out of 6 patients with axonal GBS. The antecedent infection with $C$. jejuni was shown by serum antibodies to $C$. jeju$n i$ flagellar protein in $12(71 \%)$ patients. Fifteen $(88 \%)$ patients had IgG anti-GM1 antibodies and twelve (71\%) patients had both antibodies. The high titer of anti-GM1 antibodies was found in all patients $(100 \%)$ with axonal and in $9(82 \%)$ out of 11 patients with demyelinating GBS. The association of $\operatorname{IgG}$ anti-C. jejuni and IgG anti-GM1 antibodies was found in $4(66.6 \%)$ out of 6 patients with axonal and in $8(73 \%)$ out of 11 patients with demyelinating GBS. The main features of our patients with GBS were high frequency of antecedent infection with C. jejuni, unusually frequent association with anti-GM1 antibodies, and equally frequent association of anti-C. jejuni and anti-GM1 antibodies in both, axonal and demyelinating GBS (Basta et al., 2005).

\section{Molecular Mimicry in Guillain Barré Syndrome}

The last 20 years there have been the emergence of abundant clinical data clearly showing a disease-specific correlation between peripheral neuropathies and anti-ganglioside antibodies. Many clinical and serological studies support the concept that anti-ganglioside antibodies play a key active role in pathogenesis of GBS. Experimental evidence obtained from human and animal studies continues to support the model of post infectious neuropathy as a dis- 
ease involving molecular mimicry between bacterial and neural oligosaccharides. As previously stated, in order to conclude that a disease is triggered by molecular mimicry four criteria need to be satisfied.

\section{Establishment of an epidemiological association between an infectious agent and the immune-mediated disease}

In the case of GBS there is strong epidemiological evidence for the association between acute infection with C. jejuni and GBS. Majority of GBS patients showed occurrence of neurological symptoms in no more than few weeks after the preceding infectious disease (Goodyear et al., 1999). Because of the short period between the acute infection and the development of symptoms, identification of the triggering infectious agents thru case control studies and using in vitro culture and serological techniques is possible. Therefore there is a strong and documented epidemiological evidence for the association between acute infection with $C$. jejuni and development of GBS. Those findings fulfill the first criteria for determining the infectious agent associated with the autoimmune disease (Ang et al., 2001).

\section{Identification of antibodies or T cells directed against host target antigens in patients}

In GBS patients, the association of C. jejuni infections is conferred with presence of autoantibodies against host ganglioside. The pathogenic effect of the induced antibodies or $\mathrm{T}$ cells in patients must be demonstrated in vivo or in vitro. It is very hard to satisfy this criterion, since there are a lot of experimental limitations and not always the observed symptoms directly reflect the clinical pathway of the human disease. In the acute phase serum from GBS patients, antibodies against GM1, GM1b, GD1a and GalNAc-GD1a gangliosides, are present and the specificity of these autoantibodies is closely related to the nature of the preceding infections and the pattern of clinical features of GBS (Ang et al., 2002). Therefore in GBS subtypes affecting only motor nerves (AMAN) the detected antibodies are specific for GM1, GM1b GD1a and GalNAc-GD1a gangliosides, while in Miller Fisher syndrome more present are anti-GQ1b antibodies. This means that a clinical feature of the illness is in part mediated by the ganglioside specificity which is determined by the infectious agent. The isotype of the antiganglioside antibodies in GBS patients beside the expected IgM class is presented in IgA and IgG antibodies. The IgG1 and IgG3 subclass are less expected having in mind that this is not "classical" antibody response against carbohydrate antigens, and pointing to an isotype switch involving T-cell which has been identified in the affected nerves and acute phase blood samples from GBS patients. The pathogenic effect of anti-ganglioside antibodies is mediated by binding to the Schwann cell surface, nodes of Ranvier and axons in peripheral nerves, disturbing the function and integrity of the motor nerve terminal, in a complement-dependent manner (Ariga and Yu, 2005). Therefore, the presence of ganglioside autoantibodies with neuropathogenic potential in GBS patients satisfies the criterion of identification of $\mathrm{T}$ cells or antibodies against host target antigens.

\section{Identification of microbial mimic of target antigen}

Association between GBS, previous infections and the presence of antiganglioside antibodies has been investigated most extensively in C. jejuni induced GBS. Biochemical and serological and studies showed that the LPS fraction of the outer cell wall of $C$. jejuni contains structures that mimic gangliosides (Yuki et al., 1993). The terminal tetrasaccharide of LPS extracted from a $C$. jejuni isolate of an AMAN patient was completely identical to that of the GM1 ganglioside and IgG, IgM and IgA anti-ganglioside antibodies from GBS patients recognized the C. jejuni LPS. This is strong evidence that these antiganglioside antibodies have been induced by an infection with $C$. jejuni. The complete genome of $C$. jejuni has recently become available, enabling the identification of neuropathogenic virulence factors (Parkhill et al., 2000). Serological and biochemical studies have demonstrated that the LPS fraction of $C$. jejuni contains structures that mimic gangliosides (Yuki et al., 1993). Some strains appear to have a higher potential for inducing neurological complications and this is related to the presence of specific genes in the LPS biosynthesis locus (Van Belkum et al., 2001). This comprises demonstration of cross-reactivity of autoreactive $T$ cells or antibodies with a microbial antigen, derived from an organism that has been epidemiologically linked to the disease (Kaida et al., 2009). The identification and biochemical characterization of $C$. jejuni LPS as the microbial mimic for gangliosides satisfies the third criterion for molecular mimicry.

\section{Reproduction of the disease in an animal model}

Animal models used to reproduce the disease can be achieved either by infection or by immunization with the infection agent or purified antigens in order to induce crossreactive immune response, with similar specificity, clinical symptoms and pathological features as seen in patients. Animal models are used also to investigate other aspects of proposed molecular mimicry. The first animal studies in the case of GBS, showed that immunization with $C$. jejuni or with purified LPS result in a cross-reactive antiganglioside response (Ang et al., 2001). The animals did not develop neuropathy but the anti-ganglioside antibodies generated in animals share pathogenic properties with human GBS sera. Yuki and colleagues immunized Japanese white rabbits with purified gangliosides as self-antigen and with purified $C$. jejuni LPS and induces neurological disorders, 
resulting in a neuropathy with clinical, electrophysiological and histopathological features closely resembling GBS. An animal model of AMAN was established by the sensitization of rabbits with a bovine brain ganglioside mixture. The rabbits developed high titres of IgG anti-GM1 antibodies, followed by an acute onset of flaccid limb weakness with a monophasic course which corresponds well with pathological findings for human AMAN (Yuki et al., 2004). These findings forms strong evidence that the ganglioside autoantibodies in humans can be induced by molecular mimicry between Campylobacter LPS and gangliosides, and therefore the last criterion for molecular mimicry, reproduction of the disease in an animal model is fulfilled.

\section{Conclusion}

GBS is probably the first true model of molecular mimicry having fulfilled all four criteria as follows: (i) establishment of an epidemiological association between GBS and C. jejuni infection by a prospective case-control study, (ii) identification of autoantibodies against GM1 and GD1a gangliosides in patients with AMAN subsequent to $C$. jejuni enteritis, (iii) identification of molecular mimicry between GM1 or GD1a and LPS of C. jejuni isolated from AMAN, and (iv) reproduction of the AMAN models by active immunization of rabbits with GM1 or with $C$. jejuni LPS as well as by passive transfer of anti-GD1a antibodies in mice. This makes GBS probably the first disease in humans to verify that an autoimmune disease is triggered by molecular mimicry.

Still, many key issues in the pathogenesis of GBS remain unresolved, like genetic and/or environmental host factors that confer disease susceptibility to a small number of infected individuals, specific nature of pathology according to antibody specificity, the involvement of T cell providing help to antibody production, and the nature of the immunological injuries. There is a need for a better understanding of the pathogenesis of GBS that will allow development targeted immunotherapy in order to prevent or limit the devastating injury that can result from this autoimmune-mediated neuropathy.

\section{References}

Albert, L.J., Inman, R.D., 1999. Molecular mimicry and autoimmunity. N. Engl. J. Med. 341, 2068-2074.

Ang, C.W., De Klerk, M.A., Endtz, H.P., Jacobs, B.C., Laman, J. D., Van der Meche, F.G.A., Van Doorn, P.A., 2001. GuillainBarre syndrome and Miller-Fisher syndrome-associated Campylobacter jejuni lipopolysaccharides induce anti-GM1 and anti-GQ1b antibodies in rabbits. Infect. Immun. 69, 2462-2469.

Ang, C.W., Laman, J.D., Willison, H.J., Wagner, E.R., Endtz, H.P., De Klerk, M.A., Tio-Gillen, A.P., Van den Braak, N., Jacobs, B.C., Van Doorn, P.A., 2002. Structure of Campylobacter jejuni lipopolysaccharides determines antiganglioside specificity and clinical features of Guillain-Barre and Miller Fisher patients. Infect. Immun. 70, 1202-1208.

Ang, C.W., Jacobs, B.C., Laman, J.D., 2004. The GuillainBarre syndrome: a true case of molecular mimicry. Trends Immunol. 25, 61-66.

Ariga, T., Yu, R.K., 2005. Anti-glycolipid antibodies in GuillainBarre syndrome and related diseases: review of clinical features and antibody specificities. J. Neurosci. Res. 80, $1-17$.

Asbury, A.K., Cornblath, D.R., 1990. Assessment of current diagnostic criteria for Guillian-Barre syndrome. Ann. Neurol. 27, 21-24.

Asbury, A.K., McKhann, G.M., 1997. Changing views of Guillain Barré syndrome. Ann. Neurol. 41, 287-288.

Aspinall, G.O., McDonald, A.G., Raju, T.S., Pang, H., Moran, A.P., Penner, J.L., 1993. Chemical structures of the core regions of Campylobacter jejuni serotypes O:1, O:4, O:23, and O:36 lipopolysaccharides. Eur. J. Biochem. 213, 10171027.

Aspinall, G.O., McDonald, A.G, Pang, H., Kurjanczyk, L.A, Penner, J.L., 1994. Lipopolysachharides of Campylobacter jejuni serotype O:19: Structures of core oligosaccharide regions from the serostrain and two bacterial isolates from patients with Guillain-Barre syndrome. Biochemistry 33, 241-249.

Atkinson, M.A., 1992. Islet Cell Autoantibodies Reactive to Glutamate Decarboxylase in Insulin Dependent Diabetes. J. Clin. Inves. 91, 350-356.

Basta, I., Suturkova, Lj., Vujic, A., Aleksic, S., Poceva, A., Paskoska, A., Milenikova, K., Trikic, R., Apostolski, S., 2005. Antibodies to ganglioside GM1 and Campylobacter jejuni in patients with Guillain-Barre syndrome. Srp. Arh. Celok. Lek. 133, 123-128.

Bickerstaff, E.R., 1957. Brain-stem encephalitis: further observations on a grave syndrome with benign prognosis. BMJ. 1, 1384-1387.

Damian, R.T., 1964. Molecular mimicry: antigen sharing by parasite and host and its consequences. Am. Nat. 98, 129149.

Falkow, S., 1988. Molecular Koch's postulates applied to microbial pathogenicity. Rev. Infec. Dis. 10, 274-276.

Fisher, M., 1956. An unusual variant of acute idiopathic polyneuritis (syndrome of ophthalmoplegia, ataxia and arefl exia). N. Engl. J. Med. 255, 57-65.

Goodyear, C.S., 1999. Monoclonal antibodies raised against Guillain-Barre syndrome-associated Campylobacter jejuni lipopolysaccharides react with neuronal gangliosides and paralyze musclenerve preparations. J. Clin. Invest. 104, 697708.

Griffin, J. W., Li, C. Y., Macko, C., 1996. Early nodal changes in the acute motor axonal neuropathy pattern of the Guillain Barré syndrome. J. Neurocytology 25, 33-51.

Grozdanova, A., Poceva, A., Brezovska, K., Trajkovska-Dokic, E., Apostolski, S. and Suturkova, Lj., 2011. Cross-reactive epitopes in Campylobacter jejuni strains isolated from enteritis patients. Prilozi MASA. june 2011 (in press).

Guillain, G. Barré, J.A., Ströhl, A., 1916. Sur un syndrome de radiculonévrite avec hyperalbuminose du liquid céphalorachidien sans réaction cellulaire: remarques sur les caractères cliniques et graphiques des réfl exes tendineux. Bulletins et mémoires de la Société des Médecins des Hôpitaux de Paris 40, 1462-1470. 
Hadden, R.D., Cornblath, D.R., Hughes, R.A.C., 1998. Electrophysiological classification of Guillain-Barre syndrome: clinical associations and outcome. Ann. Neurol. 44, 780-788.

Hadden, R.D., Cornblath, D.R., Hughes, R.A.C., 2001. Preceding infection, immune factors and outcome in Guillain-Barre syndrome. Neurology 56, 758-765.

Hafer-Macko, C., Hsieh, S.T., Li, C.Y., 1996. Acute motor axonal neuropathy: an antibody-mediated attack on axolemma. Ann. Neurol. 40, 635-644.

Hafer-Macko, C., Hsieh, S.T., Li, C.Y., 2000. Immune attack on the Schwann cell surface in acute inflammatory demyelinating polyneuropathy. Ann. Neurol. 39, 625-635.

Hiraga, A., Kuwabara, S., Ogawara, K., 2005. Patterns and serial changes in electrodiagnostic abnormalities of axonal Guillain-Barre syndrome. Neurology 64, 856-860.

Ho, T.W., Willison, H.J., Nachamkin, I., 1999. Anti-GD1aantibody is associated with axonal but not demyelinating forms of Guillain-Barre syndrome. Ann Neurol. 45,168-173.

Huber, S.A., Cunningham M.W., 1996. Streptococcal M protein peptide with similarity to myosin induces CD4 $+\mathrm{T}$ cell dependent myocarditis in MRL++ mice and induces partial tolerance against coxsackie viral myocarditis. J. Immunol. 156, 3528-3534.

Hughes, R.A., Rees J.H., 1997. Clinical and epidemiologic features of Guillain-Barre syndrome. J. Infect. Dis. 176, 9298.

Hughes, R.A., 1999. Pathogenesis of Guillain-Barre' syndrome. J. Neuroimmunol. 100, 74-97.

Hughes, R.A., 2005. Multidisciplinary Consensus Group. Supportive care for patients with Guillain Barré syndrome. Arch. Neurol. 62, 1194-1198.

Hughes, R.A., Swan, A. V., Raphal, J., Annane, D., Van Doorn, P.A. 2007. Immunotherapy for Guillain-Barree syndrome: a systematic review. Brain 130, 2245-2257.

Illa, I., Ortiz, N., Gallard, E., Juarez, C., Grau, J.M., Dalakas, M.C., 1995. Acute axonal Guillain-Barresyndrome with IgG antibodies against motor axons following parenteral gangliosides. Ann. Neurol. 38, 218-24.

Ilyas, A.A., Willison, H.J., Quarles, R.H., Jungalwala, F.B., Cornblath, D.R., Trapp, B.D., Griffin, D.E., Griffin, J.W., McKhann, G.M., 1988. Serum antibodies to gangliosides in Guillain-Barre syndrome. Ann. Neurol. 23, 440-447.

Jacobs, B.C., 1998. The spectrum of antecedent infections in Guillain-Barre syndrome: a case-control study. Neurology $51,1110-1115$.

Kaida, K., Ariga, T., Yu, R.K.,12009. Antiganglioside antibodies and their pathophysiological effects on Guillain-Barre syndrome and related disorders. Glycobiology 19, 676-692.

Kaufman, D.L., 1993. Spontaneous loss of T-cell tolerance to glutamic acid decarboxylase in murine insulin-dependent diabetes. Nature 366, 69-72.

Khan, F., Nag, L., 2009. Rehabilitation for Guillain Barre Syndrome. IJRT. 16, 1-8.

Kuroki, S., 1993. Campylobacter jejuni strains from patients with Guillain-Barre syndrome belong mostly to Penner serogroup 19 and contain b-N-acetylglucosamine residues. Ann. Neurol. 33, 243-247.

Kuwabara, S., Ogawara, K., Sung, J.Y., 2002. Differences in membrane properties of axonal and demyelinating GuillainBarre syndromes. Ann. Neurol. 52, 180-187.

Kuwabara, S., Ogawara, K., Misawa, S., 2004. Does Campylobacter jejuni infection elicit "demyelinating"
Guillain-Barre syndrome. Neurology. 63, 529-533.

McKhann, G. M., Cornblath, D. R., Griffin, J. W., 1993. Acute motor axonal neuropathy: a frequent cause of acute flaccid paralysis in China. Ann. Neurol. 33, 333-342.

Nachamkin, I., Allos, B. M., Ho, T. 1998. Campylobacter species and Guillain-Barre syndrome. Clin Microbiol. Rev. 11, 555567.

Nachamkin, I., 2001. Campylobacter Enteritis and the GuillainBarre Syndrome. Curr. Infect. Dis. Rep. 3, 116-122.

Nachamkin, I., Shadomy, S.V., Moran, A.P., Cox, N., Fitzgerald, C., Ung, H., Corcoran, A.T., Iskander, J.K., Schonberger, L.B., Chen, R.T., 2008. Antiganglioside antibody induction by swine $(\mathrm{A} / \mathrm{NJ} / 1976 / \mathrm{H} 1 \mathrm{~N} 1)$ and other influenza vaccines: Insights into vaccine-associated Guillain-Barre syndrome. J. Infect. Dis. 198, 226-233.

Parkhill, J., Wren, B.W., Mungall, K., Ketley, J.M., Churcher, C., Basham. D., Chillingworth, T., Davies, R.M., Feltwell, T., Holroyd, S., 2000. The genome sequence of the foodborne pathogen Campylobacter jejuni reveals hypervariable sequences. Nature 403, 665-668

Plomp, J.J., Molenaar, P.C., O'Hanlon, G.M., Jacobs, B.C., Veitch, J., Daha, M.R., Van Doorn, P.A., Van Der Meche, F.G., Vincent, A., Morgan, B.P., 1999. Miller Fisher anti-GQ1b antibodies: a-latrotoxin-like effects on motor endplates. Ann. Neurol. 45, 189-199.

Rees, J.H. Soudain, S.E., Gregson, N.A., Hughes, R.A.C., 1995. Campylobacter jejuni infection and Guillain-Barre syndrome, N. Engl. J. Med. 333(21), 1374-1379.

Rose, N.R., Bona C., 1993. Defining criteria for autoimmune diseases. Immunol. Today 14, 426-430.

Rose, N.R., Mackay I.R., 2000. Molecular mimicry: a critical look at exemplary instances in human diseases. Cell. Mol. Life Sci. 57, 542-551.

Sheikh, K.A., Nachamkin, I., Ho, T. W., Willison, H. J., Veitch, J., Ung, H., Nicholson, M., Li, C. Y., Wu, H. S., Shen, B. O., Cornblath, D. R., Asbury, A. K., McKhann, G. M., Griffin, J. W., 1998. Campylobacter jejuni lipopolysaccharides in Guillain-Barre syndrome: molecular mimicry and host susceptibility. Neurology 51, 371-378.

Van Belkum, A., 2001. A Campylobacter jejuni gene associated with immune-mediated neuropathy. Nat. Med. 7, 752-753.

Van der Meche, S., PIM, Dutch Guillain Barré Study Group. 1992. A randomized trial comparing intravenous immune globulin and plasma exchange in Guillain Barré syndrome. N. Engl. J. Med. 326, 1123-29.

Van der Meche, S., Van Doorn, P.A., 1995. GuillainBarre'syndrome and chronic inflammatory demyelinating polyneuropathy: immune mechanisms and update on current therapies. Ann. Neurol. 37, 14-31.

Van Doorn, P.A., 2008. Clinical features, pathogenesis, and treatment of Guillain-Barre syndrome, The Lancet Neurology 7(10), 939-950.

Wirguin, I., Briani, C., Suturkova-Milosevic, L., Fisher, T., Della-Latta, P., Chalif, P., Latov, N., 1997. Induction of anti-GM1 ganglioside antibodies by Campylobacter jejuni lipopolysaccharides. J. Neuroimmunol. 78, 138-142.

Yuki, N., Yoshino, H., Sato, S., Miyatake, T., 1990. Acute axonal polyneuropathy associated with anti-GM1 antibodies following Campylobacter enteritis, Neurology 40(12), 1900-1902.

Yuki, N., Taki, T., Inagaki F., 1993. A bacterium lipopolysaccharide that elicits Guillain-Barre syndrome has a GM1 gangliosidelike structure, Journal of Experimental Medicine 178(5), $1771-1775$. 
Yuki, N., Yamada M., Koga, M., 2001. Animal model of axonal Guillain-Barre syndrome induced by sensitization with GM1 ganglioside, Ann. Neurol. 49(6), 712-720.

Yuki, N., Susuki, K., Koga, M., Nishimoto, Y., Odaka, M., Hirata, K., Taguchi, K., Miyatake, T., Furukawa, K.
Kobata, T., Yamada, M., 2004. Carbohydrate mimicry between human ganglioside GM1 and Campylobacter jejuni lipooligosaccharide causes Guillain-Barre syndrome. Proc. Natl. Acad. Sci. 101, 11404-11409.

\title{
Резиме
}

\section{Улогата на молекуларната мимикрија во етиопатогенезата на Guillain Barré синдромот}

\author{
Александра Грозданова ${ }^{1}$, Слободан Апостолски², Љубица Шутуркова ${ }^{1}$ \\ 'Институт за Фармацевтска хемија, Фармаџевтски факултет, Универзитет „Св. Кирил и Методиј“, Скопје, Р. \\ Македонија \\ ${ }^{2}$ Специјалистичка ординачија „Апостолски“, Белград, Србија
}

Клучни зборови: Guillain Barré syndrome, молекуларна мимикрија, Campylobacter jejuni, липолисахариди, ганглиозиди

Молекуларната мимикрија помеѓу сопствени ткивни структури и микробни структури е предложена како патоген механизам за иницирање на автоимуни заболувања кај кои претходи инфекција. Неодамнешните испитувања посочија дека молекуларната мимикрија како можен механизам сеуште не е докажана кај најголем број на хумани заболувања. Сепак, во случајот на периферната невропатија Guillain Barré синдром (GBS) оваа хипотеза е поткрепена со огромен број на експериментални докази. GBS е најчестата причина за акутна невромускулна парализа и често се јавува по инфекција со бактеријата Campylobacter jejuni (C. jejuni). Епидемиолошките студии, покажаа дека повеќе од една третина од пациентите со GBS имале претходна инфекција со $C$. jejuni и дека само одредени серотипови на $C$. јејипi се асоцирани со развој на GBS. Молекуларната мимикрија помеѓу хуманите ганглиозиди и олигосахаридите на бактерискиот липополисахарид (LPS) најверојатно резултира со создавање на антиганглиозидни вкрстено реактивни антитела кои најверојатно се фактор кој влијае на патогенезата на GBS. Антиганглиозидните антитела се присутни во серумот на пациентите co GBS, а со сензибилизација на зајци со ганглиозиди и C. јејипi LPS воспоставени се експериментални животински модели на GBS.

GBS е класичен пример на пост инфективно имуно-посредувано заболување кое најверојатно ќе биде дефинирано како прв вистински модел на автоимуно заболување кое е резултат на молекуларна мимикрија. 



\title{
Essential oils composition of Pinus peuce Griseb. (Pinaceae) growing on Pelister Mtn., Republic of Macedonia
}

\author{
Marija Karapandzova*, Gjose Stefkov, Svetlana Kulevanova \\ Institute of Pharmacognosy, Faculty of Pharmacy, University "Ss. Cyril and Methodius", Skopje, Macedonia
}

Received: May 2011; Accepted: June 2011

\begin{abstract}
The composition of essential oils obtained by hydrodistillation from needles, from branches without needles and from branches with needles of Pinus peuce Griseb. (Pinaceae) from Pelister Mtn. (R. Macedonia) was analyzed by GC/FID/MS. One hundred and seven components (40 monoterpenes, 37 sesquiterpenes, 9 diterpenes and 21 other components - aliphatic and cyclic hydrocarbons; aliphatic alcohols, aldehydes, and acids; phenols and other oxygenated benzene derivates) were identified. The most abundant constituents were terpene hydrocarbons, encompassing the monoterpenes: $\alpha$-pinene, $\beta$-pinene, limonene $+\beta$-phellandrene and bornyl acetate and the sesquiterpenes: trans (E)-caryophyllene and germacrene D.
\end{abstract}

Key words: Pinus peuce, Macedonian pine, essential oil composition, GC/FID/MS. Natural park Pelister, locus classicus, R. Macedonia.

\section{Introduction}

Pinus peuce Griseb. (Pinaceae), commonly called Macedonian pine or Balkan pine is an endemic conifer tree inhabiting the southern and western parts of the territory of R. Macedonia. This conifer is autothonus to the Baba Mountain (Pelister), Nidze and Shara Mountain. It can be also found in Bulgaria, Albania, Serbia and Greece, growing typically at $1000-2200 \mathrm{~m}$ altitude. It is a member of the white or soft pine group (subgenus Strobus, section Strobus, subsection Strobi), and thus differes from the other pine species (P. mugo, P. nigra and P. sylvestris) growing in R. Macedonia, that belong to the yellow or hard pine group (subgenus Pinus, section Pinus, subsection Pinus).

For the first time, Pinus peuce was described on Baba Mountain (Pelister) in 1839 by Grisebach, thus this location is locus classicus for this species.

In folk medicine, pine needle essential oils are mainly used for the treatment of respiratory infections accompanied by cough, bronchitis, bronchial asthma, emphysema, tracheitis, sinusitis, laryngitis, pharyngitis, tonsillitis

\footnotetext{
Marija Karapandzova@ff.ukim.edu.mk;

marijakarapandzova@yahoo.com
}

and influenza (Dervendzi, 1992). Data from recent scientific literature suggest an increased interest in studying the composition of the essential oil isolated from different pine species as well as biological activity. Generally, monoterpenes and sesquiterpenes are dominant components of pine needle essential oils (Dob, 2007; Menkovic, 1993; Nikolic, 2007; Dob, 2006; Pagula, 2006; Dormont, 1998; Roussis, 1994; Yong-Suk, 2005; Oluwadayo, 2008, Barnola, 2000). It is important to notice that these essential oils have antimicrobial (Oluwadayo, 2008; Yong-Suk, 2005; Sacchetti, 2005), antifungal and antioxidant activity (Guri, 2006; Limei, 2008; Pinelo, 2004; Jerez, 2005; Jerez, 2006; Guolcin, 2003; Sacchetti, 2005). Because of their characteristic odor, pine essential oils are also appreciated in the cosmetic and perfume manufacture. There are several registered pharmaceuticals such as Pinimenthol ${ }^{\circledR}$ ointment which contains pine needle essential oil and is particularly suitable for the treatment for upper respiratory tract infections both in adolescents and adults (Kamin, 2007).

Nowdays, there is uprising trend of consumption of value added natural products complying different standards as Sustainable, Organic/Biological, Fare Wild etc. The populations of P.peuce in the National Park (NP) Pelister have a great resource potential and sustainable use of these natu- 
ral resources can have a significant socio-economic impact on local community. In this direction, assessment of the essential oil of P.peuce would greatly contribute in its value added portfolio.

Up to present, there are no evident data about essential oil composition of Pinus peuce population growing on NP Pelister (locus classicus) neither from any locality of the territory of R. Macedonia. On a subject of all previously mentioned, the aim to this study was to obtain data for the yield and composition of the essential oils isolated from needles, from branches without needles and from branches with needles of Pinus peuce from NP Pelister.

\section{Material and methods}

\section{Plant material}

Only terminal, up to three years old branches were collected in July, 2008 and 2009, in the NP Pelister on 4 different altitudes (1208 m.a.s.1., 1723 m.a.s.1., 1943 m.a.s.l. and 2042 m.a.s.1.). Plant identity was verified as Pinus peuce Grisebach and voucher specimens (No2008/Pp, No2009/ $\mathrm{Pp}$ ) were deposited at the Herbarium at the Department of Pharmaceutical Botany, Institute of Pharmacognosy, Faculty of Pharmacy, Skopje. Plant material was dried at room temperature and on draft for two weeks. The needles were separated from the branches just before the hydrodestillation and were properly minced.

\section{Essential oil isolation}

Essential oil isolation from plant material was made by hydrodestillation in all-glass Clevenger apparatus $(\mathrm{Ph}$. Eur 7). For that purpose, $20 \mathrm{~g}$ of plant material (needles, branches without needles and branches with needles) was distilled for 4 hours. After isolation, anhydrous sodium sulfate was added to remove residual water and to dry essential oil.

For GC/FID/MS analysis, the essential oil was dissolved in xylene $(1: 1000 \mathrm{v} / \mathrm{v})$.

\section{Gas chromatography}

Essential oil samples were analyzed on Agilent 7890A Gas Chromatography system equipped with FID detector and Agilent 5975C mass spectrometer as well as capillary flow technology which enables simultaneous analysis of the sample on both detectors. HP-5ms 5\% phenyl $95 \%$ dimethylpolysiloxane bonded phase capillary column $(30 \mathrm{~m}$ x $0.25 \mathrm{~mm}$, film thickness $0.25 \mu \mathrm{m}$ ) was used. Operating conditions were as follows: oven temperature at $60{ }^{\circ} \mathrm{C}$ for $5 \mathrm{~min}$, then increased to $80^{\circ} \mathrm{C}$ at rate of $1{ }^{\circ} \mathrm{C} / \mathrm{min}$ and held $2 \mathrm{~min}$ and at the end increased to $280{ }^{\circ} \mathrm{C}$ at rate of $5{ }^{\circ} \mathrm{C} / \mathrm{min}$ and held $5 \mathrm{~min}$; helium as carrier gas at a flow rate of $1 \mathrm{ml} /$ min; temperature of the injector $260{ }^{\circ} \mathrm{C}$ and that of the FID detector $270{ }^{\circ} \mathrm{C}$; the $\mathrm{GC}$ split ratio $1: 1.1 \mu \mathrm{l}$ of each sample was injected per GC run.

The mass spectrometry conditions were: ionization voltage $70 \mathrm{eV}$, ion source temperature $230^{\circ} \mathrm{C}$, transfer line temperature $280{ }^{\circ} \mathrm{C}$ and mass range from 50 - $500 \mathrm{Da}$. The MS was operated in scan mode.

Identification of the components present in essential oils was made by comparing mass spectra of components in essential oils with those from Nist, Wiley and Adams mass spectra libraries, by AMDIS (Automated Mass Spectral Deconvolution and Identification System) and by comparing literature and estimated Kovat's (retention) indices that were determined using mixture of homologous series of normal alkanes from $\mathrm{C}_{9}$ to $\mathrm{C}_{25}$ in hexane, under the same above mentioned conditions.

The percentage ratio of essential oils components was computed by the normalization method of the GC/FID peak areas and average values were taken into further consideration $(n=4)$.

\section{Results and discussion}

The yield of essential oils calculated on a dry mass and obtained by hydrodistillation from needles, from branches without needles and from branches with needles of $\mathrm{Pi}$ nus peuce, is given in Table 1. The obtained essential oils were transparent, light yellowish liquids with specific and strong odor.

Table 1. The yield of Pinus peuce essential oils isolated from needles, from branches without needles and from branches with needles.

\begin{tabular}{lc}
\hline \hline \multicolumn{1}{c}{ Sample } & $\begin{array}{c}\text { Yield* of essential oil } \\
(\mathrm{ml} / \mathrm{kg}) \pm \mathrm{SD}\end{array}$ \\
\hline $\begin{array}{l}\text { Pinus peuce (needles) } \\
\text { Pinus peuce (branches } \\
\text { without needles) }\end{array}$ & $4.65 \pm 1.36 \%$ \\
$\begin{array}{l}\text { Pinus peuce (branches } \\
\text { with needles) }\end{array}$ & $17.30 \pm 0.2 \%$ \\
$*(\mathrm{n}=3)$ & $7.50 \pm 0.3 \%$ \\
\hline
\end{tabular}

Table 2 shows components that were identified in the $\mathrm{Pi}$ nus peuce essential oils isolated from needles, from branches without needles and from branches with needles with their percentage amount and Kovat's retention indices. The estimated percentage values are averages of components that are present in the essential oils obtained from plant material (needles, branches without needles and branches with needles) collected from four various altitudes.

One hundred and seven components were identified in the Pinus peuce essential oils. Among them, 40 monoterpenes, 37 sesquiterpenes, 9 diterpenes and 21 other com- 
Table 2. Chemical composition of Pinus peuce essential oil from Pelister Mtn .

\begin{tabular}{|c|c|c|c|c|c|c|c|}
\hline No. & KIL & KIE & Component & $\begin{array}{c}\text { Pelister Mtn. } \\
2008 \\
(\%)-\mathrm{n}\end{array}$ & $\begin{array}{l}\text { Pelister Mtn. } \\
2009 \\
(\%)-\mathrm{n}\end{array}$ & $\begin{array}{c}\text { Pelister Mtn. } \\
2008 \\
(\%)-n+b\end{array}$ & $\begin{array}{c}\text { Pelister } \\
\text { Mtn. } 2008 \\
(\%)-\text { b }\end{array}$ \\
\hline & & & Monoterpene hydrocarbons & & & & \\
\hline 2 & 931 & 980.5 & $\alpha$-Thujene & - & - & 0.02 & 0.02 \\
\hline 3 & 939 & 983.7 & $\alpha$-Pinene & 12.89 & 19.72 & 23.77 & 23.34 \\
\hline 4 & 953 & 988.5 & Camphene & 2.69 & 5.03 & 3.68 & 0.69 \\
\hline 8 & 975 & 1000.3 & Sabinene & 0.05 & 0.08 & 0.02 & 0.02 \\
\hline 9 & 980 & 1002.8 & $\beta$-Pinene & 6.16 & 7.95 & 11.85 & 13.00 \\
\hline 10 & 991 & 1010.9 & Myrcene & 0.57 & 0.79 & 1.17 & 2.50 \\
\hline 12 & 1003 & 1019.8 & $\alpha$-Phellandrene & 0.14 & 0.34 & 0.16 & 0.05 \\
\hline 13 & 1007 & 1024.0 & $\Delta^{3}$-Carene & 0.33 & - & 0.58 & 0.79 \\
\hline 14 & 1018 & 1028.8 & $\alpha$-Terpinene & 0.05 & 0.10 & 0.05 & 0.02 \\
\hline 16 & 1025 & 1035.2 & $p$-Cymene & 0.22 & 0.80 & 0.05 & 0.05 \\
\hline 17 & 1031 & 1039.0 & Limonene $+\beta$-Phellandrene & 3.08 & 3.97 & 13.94 & 8.77 \\
\hline 19 & 1040 & 1064.3 & $\beta$-cis-Ocymene & 0.02 & - & - & - \\
\hline 22 & 1062 & 1064.5 & $\gamma$-Terpinene & 0.13 & 0.37 & 0.04 & 0.05 \\
\hline \multirow[t]{3}{*}{25} & 1088 & 1092.2 & Terpinolene & 0.50 & 0.65 & 0.37 & 0.24 \\
\hline & & & 14 components: & 26.83 & 39.80 & 55.70 & 49.54 \\
\hline & & & Oxigenated monoterpene & & & & \\
\hline 18 & 1033 & 1040.8 & 1,8-Cineole & 0.13 & 0.20 & - & - \\
\hline 27 & - & 1131.2 & trans-p-Menth-2-en-1-ol & 0.30 & 0.07 & 0.08 & 0.02 \\
\hline 28 & 1120 & 1136.4 & $\alpha$-Campholenal & 0.13 & 0.02 & 0.08 & 0.10 \\
\hline 29 & 1139 & 1144.8 & trans-Pinocarveol & 0.27 & 0.02 & 0.32 & 0.35 \\
\hline 31 & - & 1148.0 & Viridene & - & 0.02 & - & - \\
\hline 32 & 1143 & 1153.6 & Camphor & 0.06 & - & 0.02 & - \\
\hline 33 & 1144 & 1155.5 & trans-Verbenol & - & - & 0.03 & 0.06 \\
\hline 34 & 1160 & 1169.1 & trans-Pinocamphone & - & - & 0.03 & 0.05 \\
\hline 35 & 1162 & 1170.1 & Pinocarvone & 0.20 & 0.02 & 0.27 & 0.10 \\
\hline 36 & 1165 & 1172.5 & Borneol & 0.64 & 0.76 & 0.62 & 0.14 \\
\hline 37 & 1177 & 1181.9 & Terpinene-4-ol & 0.08 & 0.02 & 0.34 & 0.11 \\
\hline 38 & 1183 & 1189.4 & p-Cymene-8-ol & 0.08 & 0.02 & 0.09 & 0.10 \\
\hline 39 & 1189 & 1191.6 & $\alpha$-Terpineol & 0.30 & 0.29 & 0.51 & 0.45 \\
\hline 40 & 1193 & 1195.2 & Myrtenal & 0.29 & 0.16 & 0.32 & 0.35 \\
\hline 42 & 1205 & 1205.6 & trans-Piperitol & 0.19 & 0.20 & 0.02 & - \\
\hline 43 & - & 1207.1 & Verbenone & 0.04 & 0.06 & 0.10 & 0.19 \\
\hline 44 & 1212 & 1218.0 & trans-Carveol & 0.08 & 0.02 & 0.14 & 0.11 \\
\hline 45 & 1220 & 1219.9 & endo-Fenchyl acetate & 0.03 & 0.02 & 0.02 & - \\
\hline 46 & 1235 & 1237.1 & Thymol methyl ether & - & - & - & 0.02 \\
\hline 47 & 1243 & 1246.2 & Carvone & - & - & 0.05 & 0.04 \\
\hline 48 & - & 1254.6 & Piperitone & 0.02 & - & 0.02 & - \\
\hline 49 & 1256 & 1257.6 & Linalool acetate & 0.12 & 0.02 & 0.03 & 0.05 \\
\hline 51 & 1285 & 1285.6 & Bornyl acetate & 10.56 & 9.29 & 5.60 & 1.13 \\
\hline 55 & 1350 & 1347.5 & $\alpha$-Terpenyl acetate & 2.97 & 1.20 & 1.04 & 0.42 \\
\hline 58 & 1383 & 1380.9 & Geranyl acetate & 0.04 & - & - & - \\
\hline \multirow[t]{2}{*}{61} & 1401 & 1400.7 & Methyl eugenol & - & - & - & - \\
\hline & & & 26 components: & 16.45 & 12.59 & 10.39 & 3.79 \\
\hline
\end{tabular}




\begin{tabular}{|c|c|c|c|c|c|c|c|}
\hline No. & KIL & KIE & Component & $\begin{array}{c}\text { Pelister Mtn. } \\
2008 \\
(\%)-\mathrm{n}\end{array}$ & $\begin{array}{c}\text { Pelister Mtn. } \\
2009 \\
(\%)-\mathrm{n}\end{array}$ & $\begin{array}{c}\text { Pelister Mtn. } \\
2008 \\
(\%)-\mathrm{n}+\mathrm{b}\end{array}$ & $\begin{array}{c}\text { Pelister } \\
\text { Mtn. } 2008 \\
(\%)-\text { b }\end{array}$ \\
\hline & & & Sesquiterpene hydrocarbons & & & & \\
\hline 54 & 1339 & 1336.1 & $\delta$-Elemene & 0.21 & 0.11 & 0.13 & 0.18 \\
\hline 56 & 1373 & 1371.1 & $\alpha$-Ylangene & 0.02 & - & 0.08 & 0.12 \\
\hline 57 & 1376 & 1374.0 & $\alpha$-Copaene & 0.10 & 0.02 & 0.15 & 0.32 \\
\hline 59 & 1384 & 1383.3 & $\beta$-Bourbonene & 0.11 & 0.12 & 0.14 & 0.08 \\
\hline 60 & 1391 & 1389.2 & $\beta$-Elemene & 0.47 & 0.36 & 0.44 & 0.36 \\
\hline 62 & 1402 & 1403.4 & Longifolene & 0.02 & - & 0.19 & 0.22 \\
\hline 63 & 1418 & 1418.0 & $\operatorname{trans}(\mathrm{E})$-Caryophyllene & 7.13 & 4.88 & 4.13 & 7.30 \\
\hline 64 & - & 1430.1 & $\beta$-Copaene & 0.76 & 0.40 & 0.45 & 0.57 \\
\hline 65 & 1439 & 1444.3 & Aromadendrene & 0.04 & - & 0.03 & 0.02 \\
\hline 66 & - & 1446.8 & $\gamma$-Amorphene & 0.19 & 0.15 & 0.16 & - \\
\hline 67 & 1454 & 1453.6 & $\alpha$-Hummulene & 1.59 & 0.79 & 1.00 & 1.68 \\
\hline 68 & - & 1469.1 & $\begin{array}{l}\text { Epi-bicyclosesquiphellan- } \\
\text { drene }\end{array}$ & 0.06 & 0.52 & 0.26 & 0.31 \\
\hline 70 & 1477 & 1475.8 & $\gamma$-Muurolene & 0.15 & 0.22 & 1.34 & 2.17 \\
\hline 71 & 1480 & 1481.7 & Germacrene D & 19.90 & 8.75 & 9.47 & 10.28 \\
\hline 72 & 1485 & 1493.9 & $\beta$-Selinene & 0.03 & - & 0.28 & 0.34 \\
\hline 73 & 1494 & 1496.3 & Bicyclogermacrene & 0.99 & 1.43 & 0.12 & 0.02 \\
\hline 74 & 1495 & 1497.9 & $\alpha$-Muurolene & 0.92 & 0.25 & 0.87 & 1.60 \\
\hline 75 & - & 1507.5 & trans-Cadina-1(6)4-diene & 0.02 & - & - & - \\
\hline 76 & 1513 & 1513.7 & $\gamma$-Cadinene & 0.45 & 0.39 & 1.00 & 1.88 \\
\hline 77 & 1524 & 1525.3 & $\delta$-Cadinene & 2.71 & 1.52 & 3.06 & 4.18 \\
\hline 78 & 1532 & 1532.0 & trans-Cadina-1,4-diene & 0.06 & 0.39 & 0.12 & 0.16 \\
\hline 79 & 1538 & 1540.6 & $\alpha$-Cadinene & 0.13 & 0.31 & 0.22 & 0.27 \\
\hline 80 & 1547 & 1546.4 & $\alpha$-Calacorene & 0.02 & 0.14 & 0.10 & 0.09 \\
\hline \multirow[t]{3}{*}{83} & - & 1571.3 & $\beta$-Calacorene & 0.02 & - & 0.07 & 0.10 \\
\hline & & & 24 components: & 36.31 & 18.62 & 22.69 & 32.26 \\
\hline & & & Oxygenated sesquiterpene & & & & \\
\hline 81 & 1564 & 1561.4 & Nerolidol-(E) & 0.18 & 0.05 & 0.18 & 0.10 \\
\hline 85 & 1574 & 1577.0 & Germacrene-4-ol & 0.10 & - & - & - \\
\hline 86 & 1576 & 1583.0 & Spathulenol & 0.32 & 0.08 & 0.46 & 0.35 \\
\hline 87 & 1581 & 1586.4 & Caryophyllene oxide & 0.57 & 0.07 & 0.70 & 1.18 \\
\hline 88 & 1590 & 1598.0 & Viridiflorol & 0.03 & - & - & - \\
\hline 89 & 1592 & 1609.0 & Longiborneol & - & - & 0.02 & 0.07 \\
\hline 90 & 1606 & 1613.0 & Humulene epoxide II & 0.12 & - & 0.12 & 0.36 \\
\hline 91 & 1627 & 1637.8 & 1-epi-Cubenol & 0.07 & 0.02 & 0.16 & 0.31 \\
\hline 92 & $\begin{array}{l}1640 \\
1641\end{array}$ & $\begin{array}{l}1644.3 \\
1647.4\end{array}$ & $\begin{array}{l}\tau \text {-Cadinol (epi- } \alpha \text {-Cadinol) }+ \\
\tau \text {-Muurolol (epi- } \alpha \text {-Muurolol) }\end{array}$ & 1.58 & 0.52 & 0.64 & 0.72 \\
\hline 93 & 1645 & 1650.1 & $\alpha$ - Muurolol (Torreyol) & 0.24 & 0.23 & 0.06 & 0.34 \\
\hline 94 & 1653 & 1657.0 & $\alpha$-Cadinol & 1.99 & 0.46 & 1.16 & 1.44 \\
\hline 95 & - & 1693.1 & Amorpha-4,9-dien-2-ol & 0.17 & 0.03 & 0.37 & 0.44 \\
\hline \multirow[t]{2}{*}{96} & 1733 & 1746.3 & Oplopanone & - & - & 0.02 & - \\
\hline & & & 13 components: & 5.37 & 1.41 & 3.89 & 5.31 \\
\hline
\end{tabular}




\begin{tabular}{|c|c|c|c|c|c|c|c|}
\hline No. & KIL & KIE & Component & $\begin{array}{c}\text { Pelister Mtn. } \\
2008 \\
(\%)-\mathrm{n}\end{array}$ & $\begin{array}{c}\text { Pelister Mtn. } \\
2009 \\
(\%)-\mathrm{n}\end{array}$ & $\begin{array}{c}\text { Pelister Mtn. } \\
2008 \\
(\%)-\mathrm{n}+\mathrm{b}\end{array}$ & $\begin{array}{c}\text { Pelister } \\
\text { Mtn. } 2008 \\
(\%)-b\end{array}$ \\
\hline & & & Diterpene & & & & \\
\hline 99 & 1929 & 1946.7 & Cembrene & 0.04 & - & 0.09 & 0.14 \\
\hline 100 & - & 2009.4 & Manool oxide & 0.09 & - & 0.16 & 0.18 \\
\hline 101 & 1967 & 2013.0 & Sclarene & 0.02 & 0.06 & 0.02 & 0.06 \\
\hline 102 & 2054 & 2073.7 & Abietatriene & 0.02 & 0.02 & 0.03 & 0.06 \\
\hline 103 & 2080 & 2101.4 & Abietadiene & 0.02 & - & 0.03 & 0.06 \\
\hline 104 & - & 2166.4 & Abienol & - & - & 0.14 & 0.29 \\
\hline 105 & 2220 & 2253.2 & Sclareol & - & - & 0.03 & 0.14 \\
\hline 106 & 2263 & 2296.5 & Dehydroabietal & 0.02 & - & 0.06 & 0.22 \\
\hline \multirow[t]{3}{*}{107} & 2302 & 2332.1 & Abietal & - & 0.08 & 0.03 & 0.14 \\
\hline & & & 9 components: & 0.21 & 0.18 & 0.59 & 1.23 \\
\hline & & & Other components & & & & \\
\hline 1 & 926 & 959.9 & Tricyclene & 0.02 & 0.02 & 0.21 & 0.02 \\
\hline 5 & - & 990.1 & Benzene acetaldehyde $^{t}$ & 0.16 & 0.58 & - & - \\
\hline 6 & - & 993.6 & p-Ethyl methyl benzene & 0.04 & 2.64 & - & - \\
\hline 7 & - & 998.1 & $1,2,5$-Trimethyl benzene ${ }^{t}$ & 0.15 & 2.23 & - & - \\
\hline 11 & 1000 & 1016.7 & n-Decane & 0.34 & 3.02 & - & - \\
\hline 15 & 1023 & 1033.3 & 1,2,4- Trimethyl benzene ${ }^{t}$ & 0.02 & 0.42 & - & - \\
\hline 20 & - & 1057.2 & 2-Phenilpropanol ${ }^{\mathrm{t}}$ & 0.12 & 0.02 & - & - \\
\hline 21 & 1057 & 1058.2 & trans-Decahydronaphtalene $e^{t}$ & 0.06 & 0.39 & - & - \\
\hline 23 & 1067 & 1084.0 & m-Tolualdehide & 0.14 & 2.30 & - & - \\
\hline 24 & 1079 & 1084.4 & p-Tolualdehide & 0.50 & 1.37 & - & - \\
\hline 26 & 1099 & 1106.8 & n-Undecane & 1.10 & 1.75 & - & - \\
\hline 30 & 1261 & 1145.0 & 2.6-Dimethylphenol ${ }^{t}$ & 0.76 & 1.50 & - & - \\
\hline 41 & 1198 & 1199.2 & Dodecane $^{t}$ & 0.25 & 0.23 & - & - \\
\hline 50 & 1261 & 1263.1 & 2-Decenal ${ }^{t}$ & 0.02 & 0.12 & - & 0.02 \\
\hline 52 & 1294 & 1296.2 & Tridecane $^{t}$ & 0.02 & - & - & - \\
\hline 53 & 1314 & 1312.5 & 2E,4E-Decadienal ${ }^{t}$ & 0.02 & 0.02 & - & - \\
\hline 69 & 1473 & 1474.5 & Dodecanol & 0.15 & 0.07 & - & - \\
\hline 82 & 1568 & 1564.8 & Dodecanoic acid ${ }^{t}$ & 0.50 & 0.06 & - & - \\
\hline 84 & 1570 & 1575.2 & Hexenyl bezoate (3-Z-) & 0.05 & 0.02 & 0.04 & - \\
\hline 97 & 1762 & 1769.9 & Benzyl benzoate & 0.05 & 0.02 & 0.02 & 0.02 \\
\hline \multirow[t]{3}{*}{98} & - & 1884.5 & Hexenyl cinnamate (3-Z-) & 0.15 & 1.23 & 0.03 & 0.02 \\
\hline & & & 21 components: & 4.55 & 16.01 & 0.30 & 0.08 \\
\hline & & & TOTAL & 89.72 & 88.61 & 93.56 & 92.21 \\
\hline
\end{tabular}

$\mathrm{n}=4$; KIL - Kovat's index literature, KIE - Kovat's index estimated, $n$ - needles, $b-$ branches without needles, $n+b-$ branches with needles, $(-)$ - not found, $\mathrm{t}$ - tentative identification, No. - ordinal number of the component according to its retention time.

ponents (aliphatic and cyclic hydrocarbons; aliphatic alcohols, aldehydes, and acids; phenols and other oxygenated benzene derivates) were identified. Analysis of the essential oils composition shows variations in the content of components that are present, probably due to the impact of weather conditions throughout the year. Seasonal variability is mostly seen in the presence of monoterpenes cam- phene and $\alpha$-terpenil acetate and sesquiterpenes $\delta$-cadinene and $\alpha$-cadinol (Table 2).

The most abundant components in the needle essential oil were monoterpenes $\alpha$-pinene $(12.89 / 19.72 \%)$, $\beta$-pinene $(6.16 / 7.95 \%)$, limonene $+\beta$-phellandrene $(3.08$ $/ 3.97 \%)$ and bornyl acetate $(9.29 / 10.56 \%)$ and sesquiterpenes trans (E)-caryophyllene $(4.88 / 7.13 \%)$ and germac- 
rene D $(8.75 / 19.90 \%)$. These components represent 54.56 $\% / 59.72 \%$ of the whole needle essential oil and are likely to determine the physico-chemical characteristics as well as chemical profile of the oils.

Dominant components in the essential oil obtained from branches with needles were the same 6 components that were found in the needle essential oils, representing $68.76 \%$ of the total amount of the oil. Among
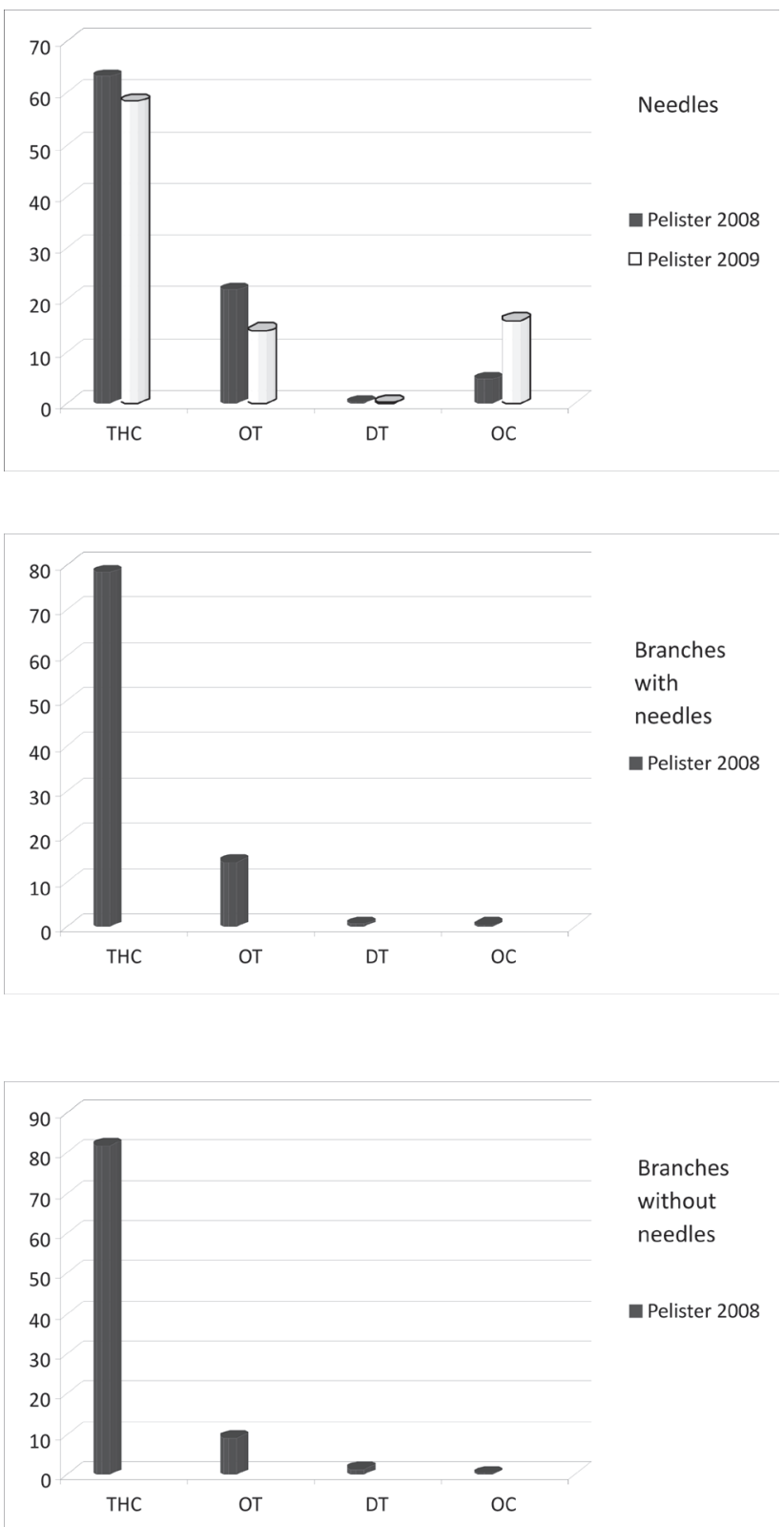

Fig. 1. Different classes of components that are present in Pinus peuce essential oils isolated from needles, from branches without needles and from branches with needles (THC - terpene hydrocarbons, OT - oxygenated terpenes, DT - diterpenes, $\mathrm{OC}$ - other components) them, $\alpha$-pinene $(23.77 \%), \beta$-pinene $(11.85 \%)$, limonene $+\beta$-phellandrene $(13.94 \%)$ were the most abundant, while germacrene D $(9.47 \%)$ and bornyl acetate $(5.60 \%)$ were present in smaller amounts.

The essential oil isolated from branches without needles contains large amount of $\alpha$-pinene (23.34\%), $\beta$-pinene $(13.00 \%)$, limonene $+\beta$-phellandrene $(8.77 \%)$, trans $(\mathrm{E})$ caryophyllene $(7.30 \%)$ and germacrene D (10.28\%), but
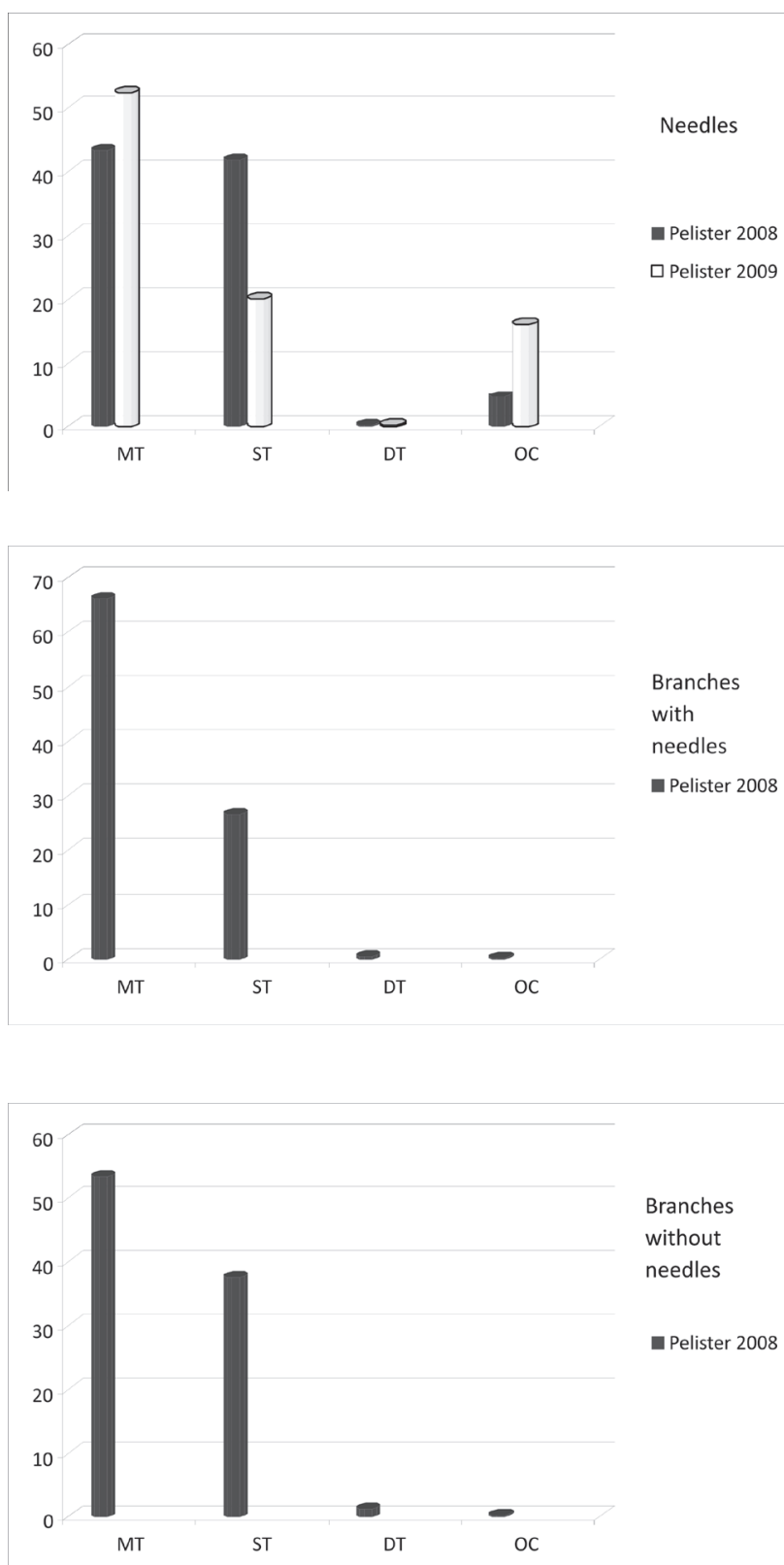

Fig. 2. Monoterpene and sesquiterpene fractions that are present in Pinus peuce essential oils isolated from needles, from branches without and from branches with needles (MT - monoterpenes, ST - sesquiterpenes, DT - diterpenes, OC - other components)

Maced. pharm. bull., $56(1,2) 13$ - 22 (2010) 
smaller amount of bornyl acetate (only $1.13 \%$ ). These components represent $63.82 \%$ of the total essential oil. It is important to notice that this essential oil contains $4.18 \%$ of $\delta$-cadinene.

Among different classes of components that are present in the needle essential oil, the major constituents were terpene hydrocarbons $(58.42 \% / 63.14 \%)$. Oxygenated terpenes were present from $14.00 \% / 21.80 \%$, other components $4.55 \% / 16.01 \%$ and diterpenes only $0.18 \% / 0.21 \%$ (Fig. 1).

The most abundant fraction among the total amount of monoterpenes and sesquiterpenes, diterpenes and other components that are present in needle essential oil were monoterpenes (43.28\%/52.39\%) (Fig. 2).

The major constituents in the essential oil obtained from branches with needles from Pinus peuce were also components that belong to terpene hydrocarbons fraction (78.39\%) and fraction of oxygenated terpenes (14.28\%) (Fig.1). The same situation was with the essential oil isolated from branches without needles which contains 81.8 $\%$ of terpene hydrocarbons fraction and $9.1 \%$ of oxygenated terpenes (Fig. 1). Diterpenes and other components were present in smaller amount $(0.59 \%$ diterpenes and $0.30 \%$ other components in the essential oil from branches with needles and $1.23 \%$ diterpenes and $0.08 \%$ other components in the essential oil isolated from branches without needles).

The most abundant fraction among the total amount of monoterpenes and sesquiterpenes, diterpenes and other components that are present in essential oil obtained from branches with needles were monoterpenes (66.09\%) (Fig. 2 ), while essential oil isolated from branches without needles contains $53.33 \%$ and $37.57 \%$ of monoterpenes and sesquiterpenes, respectively (Fig. 2).

Compared with the chemical composition of needle essential oil isolated from Pinus sylvestris (Pini sylvestris aetheroleum) and from Pinus mugo (Pini pumillionis aetheroleum) for which the European Pharmacopoeia prescribes certain limits for same components (Table 3), it is evident that the composition of needle essential oil from P. peuce is closer to the chemical composition of Pini pumillionis aetheroleum. There is no big difference in presence of $\alpha$-pinene and $\beta$-pinene between these two oils. Camphene and bornyl acetate are present in larger amount in needle essential oil from Pinus peuce while $\Delta^{3}$-carene, $\beta$-myrcene, limonene $+\beta$-phellandrene and terpinolene are present in smaller amount.

Nowdays, there are a lack of data that are relate to chemical composition of Pinus peuce essential oil. Up to now, there are only five references that are concern to the composition of the essential oils isolated from needles and branches from Pinus peuce that grows on the territory of Greece, Serbia and Montenegro (Henning, 1994; Papadopoulou, 1996; Koukos, 2000; Petrakis, 2001; Nikolic, 2008). Seventy eight components were detected, but only fifty six components were identified in the needle essential oil. $\alpha$-Pinene, camphene, $\beta$-pinene, $\beta$-phellandrene, bornyl acetate, $\beta$-caryophyllene, germacrene $\mathrm{D}$ and citronelol are declared as main components in the needle essential oil while $\alpha$-pinene, $\beta$-pinene, $\beta$-phellandrene, $\beta$-caryophyllene and citronelol are concerned as main components in the essential oil isolated from branches from $P$. peuce. Compared with essential oils isolated from $P$. peuce from Macedonia, the needle essential oil isolated from $P$. peuce from Greece contains larger amount of $\alpha$-pinene $(23.07 \%)$ and $\beta$-pinene $(22.00 \%)$ and large amount of citronellol (13.42\%), but it doesn't contain germacrene $\mathrm{D}$, while essential oil isolated from branches contains larger amount of $\beta$-phellandrene (26.93\%) and large amount of citronellol (12.48\%), smaller amount of $\alpha$-pinene $(7.38 \%)$, but it doesn't contain germacrene D and bornyl acetate. The needle essential oils isolated from $P$. peuce from Montenegro and Serbia contain larger amount of $\alpha$-pinene $(36.5 \%)$ and camphene $(8.5 \%)$, but smaller amount of bornyl acetate $(6.8 \%)$.

Table 3. Chemical composition of Pini sylvestris aetheroleum and Pini pumillionis aetheroleum (Ph. Eur 7).

\begin{tabular}{lcc}
\hline \hline \multicolumn{1}{c}{ Component } & $\begin{array}{c}\text { Pini sylvestris } \\
\text { aetheroleum }(\%)\end{array}$ & $\begin{array}{c}\text { Pini pumillionis } \\
\text { aetheroleum }(\%)\end{array}$ \\
\hline$\alpha$-Pinene & $32.0-60.0$ & $10.0-30.0$ \\
Camphene & $0.5-2.0$ & $0.0-2.0$ \\
$\beta$-Pinene & $5.0-22.0$ & $3.0-14.0$ \\
$\Delta^{3}$-Carene & $6.0-18.0$ & $10.0-20.0$ \\
$\beta$-Myrcene & $1.5-10.0$ & $3.0-12.0$ \\
Limonene & $7.0-12.0$ & $8.0-14.0$ \\
$\beta$-Phellandrene & $0.0-2.5$ & $10.0-19.0$ \\
$p$-Cymene & $0.0-2.0$ & $0.0-2.5$ \\
Terpinolene & $0.0-4.0$ & $0.0-8.0$ \\
Bornyl acetate & $1.0-4.0$ & $0.5-5.0$ \\
$\beta$-Caryophyllene & $1.0-6.0$ & $0.5-5.0$ \\
\hline
\end{tabular}

Макед. фарм. билт., 56 (1, 2) 13 - 22 (2010) 


\section{Conclusion}

The yield of needle essential oil obtained by hydrodistillation of Pinus peuce from Pelister Mtn. (Republic of Macedonia) ranged from $3.00 / 6.75 \mathrm{ml} / \mathrm{kg}$. The branches without needles contain significantly larger amounts of essential oil ( $17.30 \mathrm{ml} / \mathrm{kg})$ in terms of needles, while the values for content of essential oil in the branches with needles $(7.50 \mathrm{ml} / \mathrm{kg}$ ) were found between those obtained from needles and from the branches without needles. The obtained essential oils were transparent, light yellowish liquids with specific and strong odor.

Dominant components in the Pinus peuce essential oils obtained from needles, from branches without needles and from branches with needles were monoterpenes: $\alpha$-pinene, $\beta$-pinene, limonene $+\beta$-phellandrene and bornyl acetate and sesquiterpenes: trans (E)-caryophyllene and germacrene D. Among different classes of components in the essential oils, the major constituents were terpene hydrocarbons, both monoterpenes and sesquiterpenes, representing almost $80 \%$ of the oils.

\section{References}

Barnola, L.F., Cedeno, A., 2000. Inter-population differences in the essential oils of Pinus caribaea needles. Biochemical Systematics and Ecology 28, 923-931.

Dervendzi, V., 1992. Sovremeno lekuvanje so lekoviti bilki. Tabernakul, Skopje.

Dob, T., Berramdane, T., Chelghoum, C., 2006. Analysis of essential oil from the needles of Pinus pinaster growing in Algeria. Chemistry of Natural Compounds 41, 545-548.

Dob, T., Berramdane, T., Chelgoum, C., 2007. Essential oil composition of Pinus halepensis Mill. from three different regions of Algeria. Journal of Essential Oil Research

Dormont, L., Roques, A., Malosse, C., 1998. Cone and foliage volatiles emitted by Pinus cembra and some related conifer species. Phytochemistry 49, 1269-1277.

European Pharmacopoeia 7.0, 2010.

Grassmann, J., Hippeli, S., Vollmann, R., Elstner, E.F., 2003. Antioxidative properties of the essential oil from Pinus mugo. J. Agric. Food Chem. 51, 7576-7582.

Grassmann, J., Hippeli, S., Spitzenberger, R., Elstner, E.F., 2005. The monoterpene terpinolene from the oil of Pinus mugo L. in concert with $\alpha$-tocopherol and $\beta$-carotene effectively prevents oxidation of LDL. Phytomedicine 12, 416-423.

Gulcin, I., Buyukokuroglu, M.E., Otkay, M., Kufrevioglu, O.I., 2003. Antioxidant and analgesic activities of turpentine of Pinus nigra Arn. subsp. pallasiana (Lamb.) Holmboe. Journal of Ethnopharmacology 86, 51-58.

Guri, A., Kefalas, P., Roussis, V., 2006. Antioxidant activity of six pine species. Phytotherapy Research 20, 263-266.

Henning, P., Steinborn, A., Engewald, W., 1994. Investigation of the composition of Pinus peuce needle oil by GC-MS and GC-GC-MS. Chromatographia 38, 689-693.

Holzke, C., Hoffmann, T., Jaeger, L., Koppmann, R., Zimmer, 2006. Diurnal and seasonal variation of monoterpene and sesquiterpene emissions from Scots pine (Pinus sylvestris L.). Atmospheric Environment 40, 3174-3185.

Idzojtic, M., Kajba, D., Franjic, J., 2005. Differentiation of $F_{1}$ hybrids $P$. nigra J.F. Arnold x P. sylvestris L., P. nigra J.F. Arnold x P. densiflora Siebold et Zucc., P. nigra J.F. Arnold x $P$. thunbergiana Franco and their parental species by needle volatile composition. Biochemical Systematics and Ecology 33, 427-439.

Jerez, M., Tourino, S., Sineiro, J., Torres, J.L., Nunez, M. J., 2007. Procyanidins from pine bark: Relationships between structure, composition and antiradical activity. Food Chemistry 104, 518-527.

Jerez, M., Selga, A., Sineiro, J., Torres, J.L., Nunez, M. J., 2007. A comparison between bark extracts from Pinus pinaster and Pinus radiate: Antioxidant activity and procyanidin composition. Food Chemistry 100, 439-444.

Judzentiene, A., Slizyte, J., Stikliene, A., Kupcinskiene, E., 2006. Characteristics of essential oil composition in the needles of young Scots pine (Pinus sylvestris L.) stands growing along an aerial ammonia gradient. Chemija 17 (4), 67-73.

Kainulainen, P., Holopainen, J.K., 2002. Concentrations of secondary compounds in Scots pine needles at different stages of decomposition. Soil Biology and Biochemistry 34, $37-42$.

Kamin, W., Kieser, M., 2007. Pinimethol ointment in patients suffering from upper respiratory tract infections - A postmarketing observational study. Phytomedicine 14, 787-791.

Kupcinskiene, E., Stikliene, A., Judzentiene, A., 2008. The essential oil qualitative and quantitative composition in the needles of Pinus sylvestris L. growing along industrial traces. Environmental Pollution 20, 1-11.

Limei, Y., Zhao, M., Wang, J.S., Cui, C., Yang, B., Jiang, Y., Zhao, Q., 2008. Antioxidant, immunomodulatory and antibreast cancer activities of phenolic extracts from pine (Pinus massoniana Lamb.) bark. Innovative Food Science and Emerging Technologies 9, 122-128.

Maciag, A., Milakovic, D., Christensen, H.H., Antolovic, V., Kalemba, D., 2007. Essential oil composition and plantinsect relations in scots pine (Pinus sylvestris L.). Food Chemistry and Biotechnology 1008, 71-95.

Menkovic, N.R., Ristic, M.S., Samardzic, Z.J., Kovacevic, N.N., Tasic, S.R., 1993. Investigations of relic Pinus species . II. The essential oil of Pinus heldreichii. ISHS Acta Horticulturae. 344.

Micevski, K., 1985. Flora na SR Makedonija.

Naydenov, K., Tremblay, F., Fenton, N., Alexandrov, A., 2006. Strucure of Pinus nigra Arn. populations in Bulgaria revealed by chloroplast microsatellites and terpenes analysis: Provanance tests. Biochemical Systematics and Ecology 34, 562-574.

Nikolic, B., Ristic, M., Bojovic, S., Marin, P.D., 2007. Variability of the needle essential oils of Pinus heldreichii from different populations in Montenegro and Serbia. Chemistry and Biodiversity 4, 905-916.

Oluwadayo Sonibare, O., Olakunle, K., 2008. Chemical composition and antibacterial activity of the essential oil of Pinus caribaea from Nigeria. African Journal of Biotechnology 7 (14), 2462-2464.

Pagula, F., Baeckstrom, P., 2006. Studies on essential oil-bearing plants from mozambique: Part II. volatile leaf oil of needles of Pinus elliotti Engelm. and Pinus taeda L. Journal of Essential Oil Research 18 (1), 32-34.

Petrakis, P.V., Tsitsimpikou, C., Tzakou, O., Couladis, M., Vagias, C., Roussis, V., 2001. Needle volatiles from five Pinus species growing in Greece. Flavour and Fragrance Journal 16 (4), 249-252. 
Pinelo, M., Rubilar, M., Sineiro, J., Nunez, M. J., 2004. Extraction of antioxidant phenolics from almond hulls (Prunus amygdalus) and pine sawdust (Pinus pinaster). Food Chemistry 85, 267-273.

Roussis, V., Petracis, P.V., Ortiz, A., Mazomenos, B.E., 1994. Volatile constituents of needles of five Pinus species grown in Greece. Phytochemistry 39 (2), 357-361.

Sacchetti, G., Maietti, S., Muzzoli, M., Scaglianti, M., Manfredini, S., Radice, M., Bruni, R., 2005. Comparative evaluation of 11 essential oils of different origin as functional antioxidants, antiradicals and antimicrobials in foods. Food Chemistry 91, 621-632.

Semiz, G., Heijari, J., Isik, K., Holopainen, J.K., 2007. Variation in needle terpenoids among Pinus sylvestris L. (Pinaceae) provenances in Turkey. Biochemical Systematics and Ecology 35, 652-661.

Stevanovic, T., Garneau, F.X., Jean, F.I., Gagnon, H., Vilotic, D., Petrovic, S., Ruzic, N., Pichette, A., 1998. The essential oil composition of Pinus mugo Turra from Serbia. Wiley InterScience Research Article.

Tognolini, M., Barocelli, E., Ballabeni, V., Bruni, R., Bianchi, A., Chiavarini, M., Impicciatore, M., 2006. Comparative screening ofplant essential oils: Phenylpropanoid moiety as basic core for antiplatelet activity. Life Science 78, 14191432.

Ucar, G., Balaban, M., 2004. Volatile needle extractives of Anatolian black pine varieties: $P$. nigra subsp. pallasiana var. pallasiana and var. pyramidata. Biochemical Systematics and Ecology 32, 983-992.

Ustun, O., Sezik, E., Kurkcuoglu, M., Baser, K.H.C., 2006. Study of the essential oil composition of Pinus sylvestris from Turkey. Khimiya Prirodnykh Soedinenii 1, 22-25.

Youg-Suk, K., Dong-Hwa, Sh., 2005. Volatile components and antibacterial effects of pine needle (Pinus densiflora $\mathrm{S}$. and Z.) extracts. Food Microbiology 22, 37-45.

\title{
Резиме
}

\section{Хемиски состав на етерично масло од молика (Pinus peuce Griseb., Pinaceae) од Пелистер, Р. Македонија}

\author{
Марија Карапанџова*, Ѓоше Стефков, Светлана Кулеванова
}

\begin{abstract}
Институт за Фармакогнозија, Фармацевтски факултет, Универзитет “Св. Кирил и Методиј”, Скопје, Р. Македонија
\end{abstract}

Клучни зборови: Pinus peuce, македонски бор, хемиски состав на етерично масло, GC/FID/MS, Национален парк Пелистер, locus classicus, Р. Македонија.

Анализата на хемиски состав на етерични масла добиени со дестилација со водена пареа од иглички, од гранки без иглички и од гранки со иглички од молика (Рinus реисе Griseb., Pinaceae) собрана на Пелистер (P. Македонија) е направена со GC/FID/ MS. Вкупно се идентификувани сто седум компоненти (40 монотерпени, 37 сесквитерпени, 9 дитерпени и 21 други соединенија - алифатични и циклични јаглеводороди; алифатични алкохоли, алдехиди и киселини; феноли и други оксидирани деривати на бензенот). Најзастапени компоненти се компонетите од класата на терпенските јаглеводороди, вклучувајќи ги монотерпените $\alpha$-пинен, $\beta$-пинен, лимонен $+\beta$-феландрен и борнил ацетат и сесквитерпените trans (E)-кариофилен и гермакрен D. 



\title{
Assessment of Patient Satisfaction with Pharmaceutical Community Services in R. Macedonia
}

\author{
Zoran Sterjev*, Bogdan Vlaco, Aleksandra Kapedanovska Nestorovska, Zorica \\ Naumoska, Aleksandra Grozdanova, Ljubica Suturkova
}

National Drug Information Centre, Faculty for Pharmacy, University St. Cyril and Methodius - Skopje, R.Macedonia

Received: May 2011; Accepted: June 2011

\begin{abstract}
Measuring and analyzing patients' satisfaction with pharmacist's consultation is a relatively new development which is enforced by the new demands of society. High number of variables, such as their state of health, socio-demographic variables (age, sex, and cultural level), characteristics of their healthcare provider (affective care, quantity of information, technical expertise, etc), or waiting time are related to patients' satisfaction. At present, in R.Macedonia, there are 834 community pharmacies, which accounts for pharmacy vs. population ratio of 1:2500. The pharmacies are situated in 8 different regions (the Vardar region, Pelagonia, North-East, South-West, Polog, East and South East). The present cross-sectional descriptive study based on interview data was carried out in order to ascertain patients' satisfaction from their experience with the cumulative quality of pharmaceutical services. A total of 651 patients of both sexes $(59,3 \%$ male and $39,1 \%$ female) were included in the study. The results from our analysis showed the influence of different factors in the process of choosing pharmacy: distance, medicines price, well-stocked with medicines, professional advice by the employees in the pharmacy, hygiene in pharmacies, the privacy they offer, waiting time, possibility for private conversation with professionals.
\end{abstract}

Key words: pharmacy, patients' satisfaction, pharmaceutical community service, R.Macedonia

\section{Introduction}

Optimization of the patient's health-related to the quality of life and achieving positive clinical outcomes, within realistic economic expenditures is one of the primary goals of the pharmaceutical services. Community pharmacy practice is inspired by the changing philosophy of practice where the patient is in focus, rather than the physical drug products or the business aspects of pharmacy. Recently, the role of the pharmacists is changing from traditional drug dispensing to a more active and participative role in risk assessment, risk management, and other medicationrelated consultation activities (Traveso et al., 2007).

The patients evaluation of the care provided has become a prominent method of assessing the quality of health care services (Rubin et al., 1993). It mainly refers to the pa-

\footnotetext{
"zost@ff.ukim.edu.mk
}

tient's satisfaction with the health care services and providers (Sitizia and Wood, 1997). Measuring and analyzing patient's satisfaction with consultations provided by pharmacists is a relatively new strategy which is enforced by the new demands of society.

High number of variables, such as their state of health, socio-demographic variables (age, sex, and cultural level), characteristics of their healthcare provider (effective care, quantity of information, technical expertise, etc), or waiting time are related to patients' satisfaction (Marquez-Peiro and Perez-Peiro, 2008). At present, in R. Macedonia, there are 834 community pharmacies, which accounts for pharmacy vs. population ratio of 1:2500. All community pharmacies are licensed and regulated by the Ministry of Health through the Drug Bureau. Privatization of pharmacies was allowed since 2004. Most of the pharmacies are concentrated in the urban areas. Numerous rural settlements have no/limited access to a pharmacy. Almost $30 \%$ of the total number of pharmacies is located in the capital city of our 
country. The other pharmacies are located at the 7 statistical regions of pharmacies in the country (Pelagonia, the Vardar region, North- East, South-West, Polog, East and South East) according to the official pharmacy network in R.Macedonia.

The Drug Bureau announced officially that in order to be licensed, a pharmacy should consist of at least one licensed graduated pharmacist and one licensed pharmaceutical technician (Official Gazette of the Republic of Macedonia 106/2007).

The present study was carried out in order to ascertain the levels of patients satisfaction with pharmaceutical service taking into consideration the social, traditional and professional aspects of the pharmaceutical health care system in R.Macedonia.

\section{Methods}

Two month's cross-sectional descriptive study based on interview data was carried out in order to establish patients' satisfaction with the cumulative quality of pharmaceutical service based on their experience. The specially developed and designed questionnaire for measuring patients' satisfaction with pharmaceutical service was used. The multiple-choice questionnaire was prepared in accordance with "14 rules for writing multiple-choice question" (Brigham Young University). One of the questions concerning the hygiene in pharmacies, well-stocked with medicines, time of waiting and possibility of clients to have private conversation with professionals was prepared in conformity with Likert Scaling. The questionnaire consisted of 12 questions divided in the following sections: demographic profile of the responders; aspects of pharmaceutical practice; important factors for choosing a community pharmacy, contentment for receiving both verbal and written medication information in community pharmacies and aspects/issues concerning national drug policy. The eligible, randomisely selected patients, on voluntary and confi- dential basis, were interviewed in front of /inside community pharmacies in different regions of R.Macedonia (Skopje, Pelagonia, the Vardar, North East, South-West, Polog, East and South-East region). Inclusion criteria for participation in the study were age (above 16), Macedonian citizenship and willingness of the subject to participate in the study. For the statistical analysis, Kruskal-Wallis test was used for testing the hypothesis that a number of unpaired samples originate from the same population. Group comparisons were made using Chi square test for qualitative variables. Statistical significance was assessed at $\mathrm{p} \leq 0.05$.

\section{Results and Discussion}

A total of 651 patients of both sexes $(59,3 \%$ male and $39,1 \%$ female) were included. The structure of respondents regarding the territorial distribution by different regions (Skopje, Pelagonia, the Vardar, North East, SouthWest, Polog, East and South-East region), marked by numbers from 1 to 8 , and population coverage by the pharmacies where data collection took place are show in Table 1. The statistical analysis doesn't include the South-Eastern region due to the low frequency of occurrence of only $1,7 \%$ in the total structure.

The results from our analysis showed the influence of different factors in the process of choosing a pharmacy: the distance is mainly the most important element for the patients from the North-Eastern region - 51,7\%. The price of medicines, as a rule, determines the selection of a pharmacy with patients living in the territory of the Vardar and North- Eastern region (23,2\% and 24,2\% respectively). Respondents from the South- Western region mainly select the pharmacy which is well stocked - 39,5\%. Professional advice by the employees in the pharmacy is of higher priority for the respondents from the region of Pelagonia - 22,2\%, Eastern region - 24,2\% and South-East region $-28,6 \%$.The results obtained are in line with our expectation that various factors influence the process of choosing pharmacies in different re-

Table 1. Structure of respondents regarding the territorial distribution by different regions

\begin{tabular}{|c|c|c|c|c|c|c|c|}
\hline & Regions & Count & Cumulative & Percent & Cumulative & $\begin{array}{l}\text { Number of phar- } \\
\text { macies in the re- } \\
\text { gion }\end{array}$ & $\begin{array}{l}\text { Population cov- } \\
\text { er by pharmacy }\end{array}$ \\
\hline 1. & Skopje & 351 & 351 & 53,75191 & 53,7519 & 247 & 617500 \\
\hline 2. & Pelagonia & 72 & 423 & 11,02603 & 64,7779 & 127 & 317500 \\
\hline 3. & Vardar & 56 & 479 & 8,57580 & 73,3538 & 57 & 142500 \\
\hline 4. & North-East & 29 & 508 & 4,44104 & 77,7948 & 59 & 147500 \\
\hline 5. & South-West & 38 & 546 & 5,81930 & 83,6141 & 92 & 230000 \\
\hline 6. & Polog & 36 & 582 & 5,51302 & 89,1271 & 106 & 265000 \\
\hline 7. & East & 58 & 640 & 8,88208 & 98,0092 & 77 & 192500 \\
\hline \multirow[t]{2}{*}{8.} & South-East & 11 & 651 & 1,68453 & 99,6937 & 78 & 195000 \\
\hline & Missing & 2 & 653 & 0,30628 & 100,0000 & & \\
\hline
\end{tabular}


Table 2. Differences in the answers to the question "Do you take your medicines from the same pharmacy?" among the respondents from different regions

Kruskal-Wallis test: $\mathrm{H}(6, \mathrm{~N}=640)=15,85 \mathrm{p}=, 01$

\begin{tabular}{lcccccccccc}
\hline Doyou take your medicines from the same pharmacy? & 1 & 2 & 3 & 4 & 5 & 6 & 7 & 8 & row \\
& $\mathrm{N}$ & 49 & 15 & 11 & 10 & 13 & 11 & 10 & 3 & 122 \\
Always & $\%$ & 13,8 & 20,8 & 19,6 & 34,5 & 34,3 & 30,5 & 17,3 & 42,9 & \\
& $\mathrm{~N}$ & 165 & 39 & 21 & 13 & 11 & 15 & 27 & 1 & 292 \\
From the same pharmacy if the medicines I & $\%$ & 47,1 & 54,2 & 37,5 & 44,8 & 28,9 & 41,7 & 46,5 & 14,3 & \\
need are available & $\mathrm{N}$ & 137 & 18 & 24 & 6 & 14 & 10 & 21 & 3 & 233 \\
I don't have "my pharmacy" & $\%$ & 39,1 & 25,0 & 42,9 & 20,7 & 36,8 & 27,8 & 36,2 & 42,8 & \\
Column & & 351 & 72 & 56 & 29 & 38 & 36 & 58 & 7 & 647 \\
\hline
\end{tabular}

1-Skopje region, 2- Pelagonyan, 3-Vardar, 4- Nort-East, 5- South-West, 6- Polog, 7- Easterly, 8- South-East

gions. This process is probably due to differences in ethnicity, education level, social, financial and demographic factors.

We also tested out the combinations of these four offered responses which refer to the potential priorities when choosing a pharmacy, and the statistical differences in priorities when selecting a pharmacy for patients from different regions were confirmed as highly significant, i.e. important $(\mathrm{p}<0.001)$. We evaluated the differences in the answers of the question "Do you always take your medicines from the same pharmacy?". The highest percentage of patients coming from the region of Skopje $(47,1 \%)$, Pelagonia $(54,2 \%)$, from North-East region $(44,8 \%)$, from Polog region $(41,7 \%)$, and from the Eastern region (46,5\%) answered that they take their necessary medicines from the same pharmacy, if they are available. The tested difference in the answers to the question among the respondents from different regions is statistically significant and it is the result of the considerable difference between Skopje and Pelagonia region, Skopje and NorthEastern region, between the Vardar and North-Eastern region as well as between the Polog and the Eastern region. (Table 2). The introduction of fixed prices for prescribing medicines a few years ago, can be the reason which influences the patients' perception of the quality of the pharmaceutical service as a main factor for choosing the pharmacy.

Results which refer to the hygiene-related grade marks given by the respondents coming from different regions show the lowest average grade mark of 4,4 for the pharmacies from the Polog and the Eastern region, while the pharmacies in the North-East region were given the highest average mark. Half of the respondents coming from all the regions gave the maximum mark of 5 related to the hygiene in pharmacies. A statistically significant difference $(\mathrm{p}>0.05)$ was not registered. The patients' perception and satisfaction with the waiting time differ significantly among the regions. The data obtained are presented in Table 3.

The answers of respondents from different regions differ significantly in their grading of the possibility for private conversation with a pharmacist without being overheard by someone else in the pharmacy. This parameter average marks are low for all the regions and they range from 2,1 for pharmacies on the territory of North-East region, 2,4 for the Skopje region to 3,5 for pharmacies in the

Table 3. Respondents from different regions about the waiting time in pharmacies

\begin{tabular}{ccccc}
\hline \hline 54 Kruskal-Wallis test: $\mathrm{H}(6, \mathrm{~N}=631)=72,80704 \mathrm{p}=, 0000$ & \\
\hline Regions & Valid N & Mean & Std.Dev. & Median \\
Skopje & 345 & 3,4 & 1,1 & 3,0 \\
Pelagonia & 71 & 4,1 & 1,0 & 4,0 \\
Vardar & 56 & 3,9 & 0,8 & 3,0 \\
Nort-East & 28 & 3,5 & 0,8 & 4,0 \\
South-West & 38 & 4,6 & 0,7 & 5,0 \\
Polog & 36 & 3,8 & 0,9 & 4,0 \\
East & 57 & 3,8 & 1,1 & 4,0 \\
South-East & 12 & 3,2 & 1,1 & 3,0 \\
\hline
\end{tabular}

Макед. фарм. билт., 56 (1, 2) 23 - 28 (2010) 
Table 4. The possibility of having private conversation with a professional staff member in the pharmacy according to different regions.

\begin{tabular}{lcccc}
\hline \hline 55 Kruskal-Wallis test: $\mathrm{H}(6, \mathrm{~N}=626)=48,25485 \mathrm{p}=, 0000$ & & & \\
\hline Regiones & Valid $\mathrm{N}$ & Mean & Std.Dev. & Median \\
Skopje & 340 & 2,4 & 1,4 & 2,0 \\
Pelagonia & 70 & 3,4 & 1,5 & 4,0 \\
Vardar & 56 & 2,9 & 1,5 & 2,0 \\
Nort-East & 29 & 2,1 & 0,9 & 2,0 \\
South-West & 38 & 3,5 & 1,6 & 4,0 \\
Polog & 35 & 2,5 & 1,1 & 3,0 \\
East & 58 & 3,2 & 1,6 & 3,0 \\
South-East & 12 & 2,8 & 1,7 & 3,0 \\
\hline
\end{tabular}

Table 5. Evaluation of the patients' communication with professionals in pharmacies

\begin{tabular}{lcccccccccc}
\hline \hline Kruskal-Wallis test: $\mathrm{H}(6, \mathrm{~N}=640)=64,83320$ & $\mathrm{p}=, 0000$ \\
\hline In the pharmacy, patients have a contact & & 1 & 2 & 3 & 4 & 5 & 6 & 7 & 8 & Row \\
with .... & $\mathrm{N}$ & 73 & 43 & 31 & 7 & 22 & 13 & 18 & 3 & 210 \\
Pharmacist & $\%$ & 20,8 & 59,7 & 55,4 & 24,2 & 57,9 & 36,1 & 31,1 & 42,9 & \\
& $\mathrm{~N}$ & 61 & 10 & 9 & 6 & 0 & 3 & 16 & 1 & 106 \\
Pharmaceutical technician & $\%$ & 17,4 & 13,9 & 16,1 & 20,7 & 0 & 8,3 & 27,6 & 14,3 & \\
& $\mathrm{~N}$ & 217 & 19 & 16 & 16 & 16 & 20 & 24 & 3 & 331 \\
Undefined & $\%$ & 61,8 & 26,4 & 28,5 & 55,1 & 42,1 & 55,6 & 41,3 & 42,8 & \\
Column & & 351 & 72 & 56 & 29 & 38 & 36 & 58 & 7 & 647 \\
\hline
\end{tabular}

South-West region. (Table.4). Unfortunately, there is a lack of space, time and habit for private consultation in almost all pharmacies in our country. The reason for this might be the number of licensed pharmacists, suitable facilities and patients' expectations for this type of services.

While most of the respondents that contacted the pharmacist were from the region of Pelagonia - 43(59,7\%) and the Vardar region $-31(55,4 \%)$, most of the respondents from the Eastern region contacted the pharmaceutical technician $-16(27,6 \%)$. It is also interesting to note that as many as $217(61,8 \%)$ respondents from the region of Skopje were unable to answer this question since they did not know the educational level of the provider of pharmaceutical services.. The difference in the distribution of answers given by the respondents from different regions is statistically highly significant $(\mathrm{p}<0.0001)$. (Table 5)

Patients cannot distinguish between the pahramceutical care provided by licensed pharmacists and pharmaceutical technicians. We believe that the quality of pharmaceutical services given to the patients is the major reason which is responsible for this evaluated situation. The following results are in accordance with our assumptions.

The grade mark given by patients from various regions regarding the employees in the pharmacy, with regard to the information they are supplied with, differs significantly. Most frequently, the staff in the pharmacy gives the necessary information to $61,9 \%$ of patients in the region of Pelagonia, $75,9 \%$ in the North-East region, $71,1 \%$ in the SouthWest and $71,4 \%$ in the Eastern region, without even being asked. The staff gives the necessary information upon patients' request according to $53,6 \%$ of the respondents in the Vardar region and 53,4\% in the Eastern region. The lowest number of respondents answering that they were not given the necessary information is registered in the Eastern region $-1,8 \%$. None of the respondents from the North-East and South-West region answered that the pharmacy staff was unable to give them the necessary information. The respondents from various regions differ significantly regarding the confidence they have in the pharmacist or pharmaceutical technician $(\mathrm{p}<0.001)$. The patients from the South-West region have considerably higher confidence in the professional staff in the pharmacy compared to those coming from Skopje, Vardar, Polog and Eastern regions. 14,2\% of the patients from Skopje, 10,7\% from Vardar region, 8,3\% of the patients from the Polog region have no confidence in the pharmacy staff. All medicines prescribed by a physician were found in the pharmacy by $59,1 \%$ of the respondents in the region of Skopje, $70,8 \%$ in the Pelagonia region, 55,3\% 
in the Varda regionr, $79,3 \%$ in the North-East region, $89,5 \%$ in the South-West region, and 66,7\% in the Polog and Eastern regions. No respondents from the North-East, SouthWest, Polog and Eastern regions answered that they didn't find any of the prescribed medicines. The difference tested among the respondents from various regions with regard to the question of whether they could find all the medicines, part of the medicines or none of the medicines, is statistically highly significant $(p<0,001)$. The patients from the South-West region were able to find all the required medicine in the pharmacy in comparison with those from the region of Skopje, Pelagonia, Vardar, Polog and Eastern regions. The respondents from the North-East region find all the required medicines significantly more frequently than the ones from the region of Vardar. The patients are satisfied with the well stocked pharmacies on the well established pharmaceutical market in our country.

\section{Conclusion}

The present cross-sectional descriptive study is the first evaluation of the patients' satisfaction with pharmaceutical community services in R.Macedonia.The results obtained are preliminary and improvements are needed to identify the specific reasons for satisfaction/dissatisfaction with pharmaceutical services. Future research should be focused on developing a new instrument for measuring different levels of services provided by pharmacists.

\section{References}

Larson, L.N., Roverse, J.P., MacKeigan, L.D, 2002. Patient satisfaction With Pharmaceutical Care: Update of a Validated Instrument. J. Am. Pharm. Assoc. 42, 44-50.

Ministry of health, Macedonian government, 2007. Law on medical products and medical devices. Official Gazette of the Republic of Macedonia 106.

Marquez-Peiro, J.F., Perez-Peiro, C., 2008. Evaluation of Patient satisfaction in Outpatient Pharmacy. Farm. Hosp. 32 (2), 7176.

Rubin, H.R., Gandek, B., Rogers, W.H., Kosinski, M., Mc Horney, C.A., Ware, J.E.Jr., 1993. Patients ratings of outpatient visits in different practice settings: results from the Medical Outcomes Study. JAMA. 270, 835-840.

Sitizia, J., Wood, N., 1997. Patient satisfaction: a review of issues and concepts. Soc.Sci.Med. 45, 1829-1843.

Traveso, M.L., Salamano, M., Botta, C., Colautti, M., Palchik, V., Perez, B., 2007. Questions to asses patient satisfaction with pharmaceutical care in Spanish language. Int. J. Quality in Health Care. 19 (4), 217-224.

\title{
Резиме
}

\section{Определување на задоволството на пациентите од јавниот фармацевтски сервис во Р. Македонија}

\author{
Зоран Стерјев*, Богдан Влачо, Александра Капедановска Несторовска, Зорица \\ Наумоска, Александра Грозданова, Љубица Шутуркова
}

Национален Фармакоинформативен Центар. Универзитет „Св. Кирил и Методиј““ Скопје, Р.Македонија

Клучни зборови: аптека, задоволство на пациентот, фармацевтски сервис, Р. Македонија

Евалуацијата на стекнатото задоволство на пациентите од добиената фармацевтска грижа претставува релативно нов потфат предизвикан од современите потреби на општеството. Стекнатото задоволството на пациентите е условено од голем број на фактори како што се: нивната здраствена состојба, социо-демографките фактори (години, пол и културолошко ниво), карактеристиките на здравствени работници (потполна грижа, содржина и квантум на информации, техничка подготвеност итн.) или времето на чекање. Денес, во Р. Македонија има 834 јавни аптеки, со вкупна популациска распределба 1:2500 жители. Аптеките се распределени во 7 различни региони (Пелагониски, Вардарски, Североисточен, Југозападен, Полошки, Источен и Југоисточен). Спроведената студија претставува вкрстена студија, која се темели на податоци добиени од спроведени интервјуа со 651 корисник на фармацевтски услуги (59,3\% од машки и $39,1 \%$ од женски пол). Основната цел на испитувањето беше да се одреди задоволството на пациентите од добиената фармацевтска грижа и да се оцени квалитетот на истата. Резултатите од спроведената анализа упатуваат на влијание на различни фактори при процесот на избор на аптеката: оддалеченоста, цената на чинење на лековите, снабденоста со лековите, професионалните совети добиени од вработените во аптеката, хигиената во аптеката, овозможената приватноста во аптеките, времето на чекање, како и можноста за дискретен разговор со здравствените професионалци. 



\title{
TLC and GC-MS Analyses of Essential Oil Isolated from Macedonian Foeniculi fructus
}

\author{
Menče Najdoska ${ }^{1}$, Jane Bogdanov ${ }^{1 *}$, Zoran Zdravkovski $^{1}$ \\ ${ }^{1}$ Institute of Chemistry, Faculty of Natural Sciences and Mathematics, "Sts. Cyril and Methodius University" Arhimedova \\ 5, MK-1001, Skopje, Republic of Macedonia
}

Received: February 2011; Accepted: May 2011

\begin{abstract}
Summary
The essential oil of Foeniculi fructus, the ripe fruit from the plant Foeniculum vulgare Mill. ssp. vulgare var. dulce Batt. and Trab. (sweet fennel, македонски анасон) was isolated and the main components were identified and quantified using thin-layer chromatography (TLC) and gas chromatography and mass spectrometry (GC-MS). The Aetherloeum Foeniculi had pale yellow color and characteristic pleasant odor and was obtained in 3.2\% yield (by weight from the plant fruits). The main components of the oil were: trans-anethole, 1 , (70\%), $p$-anisaldehyde, 2, (19\%) estragole, 3, (6\%) and anisacetone, 4, (2\%). The identity of the components was determined by matching the mass spectra to the library spectra. The identity of the main component, trans-anethole, was confirmed directly by isolation using column chromatography and indirectly by potassium permanganate oxidation of the essential oil. The oxidation product from this reaction, $p$ methoxybenzoic acid, 16, was isolated and characterized. The potential products of autooxidation of trans-anethole (epoxy anethole, anethole glycol and 16) were not detected in the freshly obtained essential oils.
\end{abstract}

Key words: Foeniculum vulgare Mill. ssp.vulgare var. dulce, sweet -fennel fruit essential oil, chemical composition, GC-MS, transanethole.

\section{Introduction}

The charastersistic aromas of the plants are due to volatile or essential oils, which have been used since the antiquities as a source of fragrances and flavorings (Lawless, 1995). These oils occur in all the living parts of the plant, but they are usually concentrated in twigs, flowers and seeds. Essential oils are generally complex mixtures of various classes of organic compounds such as hydrocarbons, alcohols, and carbonyl compounds.

Essential oil from Foeniculi fructus (sweet fennel, Roman fennel, Macedonian fennel, mac. сладок анасон) is obtained from the ripe and dry fruits of the plant Foeniculum vulgare Mill. ssp. vulgare var. dulce Batt. and Trab., (Dervendji, 1986). It is usually cultivated in the countries of Southern Europe (France, Italy and Macedonia). The most common way to obtain essential oil of sweet fennel

\footnotetext{
j_b_bogdanov@yahoo.com
}

fruits is by steam distillation of the crushed (milled) fruits. The fruits contain between $2-6 \%$ by weight of the essential oil (Dervendji, 1986; Guenther, 1952; Kulevanova, 2004). The essential oil, Aetheroleum Foeniculi, is clear, mobile, colorless or pale yellow liquid with pleasant aromatic smell and delicate sweet flavor (Dervendji, 1986; Guenther, 1952; Kulevanova, 2004). It has a widespread use in food, beverage, fragrance and pharmaceutical industry and also finds use in the folk medicine. The fennels fruits has been used as an antispasmodic, carminative, diuretic, expectorant, laxative, stimulant and stomachic and have a long history of use in both Western and Eastern cultures. As far as Macedonia is concerned, the most famous use of sweet fennel fruits is in the preparation of the alcoholic drinks "mastika" and "anasonka" (Dervendji, 1986; Kulevanova, 2004).

The chemical composition of the essential oil derived from sweet fennel fruits varies widely depending on geographic location, climate and cultivation. The oils of sweet fennel seeds, obtained by steam distillation, most common- 

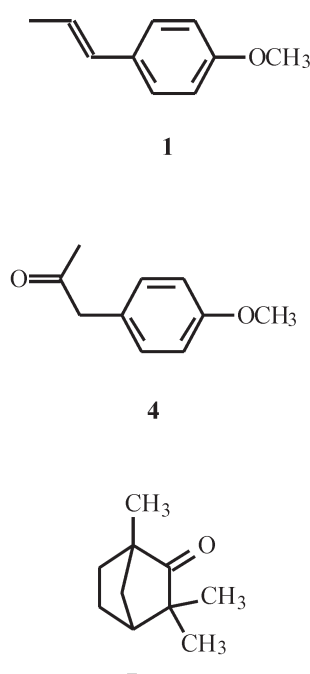<smiles>CC1CC2(C)CCC1C(C)(C)O2</smiles>

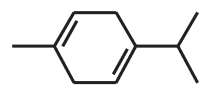

13

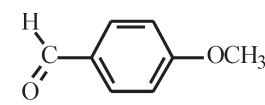

2
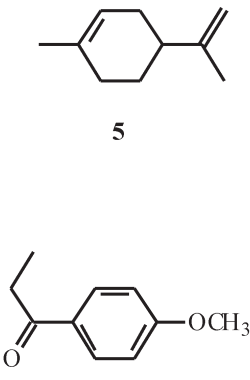

8

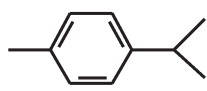

11

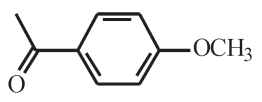

14
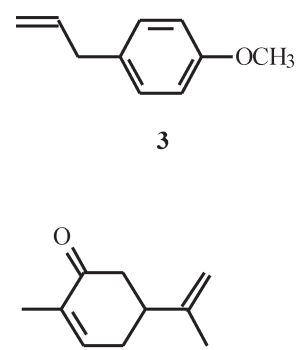

6
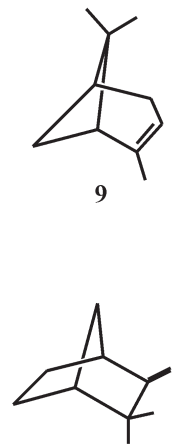

12

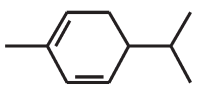

15

Fig. 1. Chemical constituents of fennel essential oil: (1) trans-anethole, (2) $p$-anisaldehyde, (3) estragole, (4) aniseacetone, (5) limonene, (6) carvone, (7) d-fenchone, (8) 4-methoxypropiophenone, (9) $\alpha$-pinene, (10) eucaliptol, (11) $p$-cymene, (12) camphene, (13) $\gamma$-terpinene, (14) $p$-methoxyacetophenone, (15) $\alpha$-phelandrene.

ly contain: trans-anethole, $\mathbf{1}, p$-anisaldehyde $\mathbf{2}$, estragole, 3, anisacetone, 4, limonene, 5, carvone, 6, d-fenchone, 7, 4-methoxypropiophenone, $\mathbf{8}, \alpha$-pinene 9 , eucaliptol 10, $p$ cymene 11, camphene, 12, $\gamma$-terpinene, 13, $p$-methoxyacetophenone, 14, and $\alpha$-phelandrene 15 (Azeez, 2008; Krishna 2004). It can be seen from scheme 1 that the essential oil is dominated by phenylpropanoids and monoterpenes. It has been established that the main constituent of the sweet fennel is trans-anethole (60-89\%). It has been established that the higher the content of trans-anethole and lower the content of fenchone results in sweet fennel oil of higher quality. For comparison purposes, bitter fennel oil is thought to contain more fenchone (12-25\%) and less transanethole $(55-75 \%)$ than sweet fennel oil (Ph. Eur. $7^{\text {th }}$ ed.). Sweet fennel oil is of a superior quality with a more pleasing aroma and flavor.

Even though, the chemical composition of the sweet fennel essential oil can vary depending on the geographic region and climate, there are some substantial discrepancies in the literature over the abundance of the other compounds especially fenchone, estragole, limonene and anisaldehyde. Karlsen and co-workers (1969) have report- ed composition of sweet fennel oil with $52.0 \%$ anethole, $2.5 \%$ estragole, $28.9 \%$ limonene and $2.7 \%$ fenchone. Akgül and Bayrak (1988) have done studies on fennel grown in Turkey and found on average $75-85 \%$ trans-anethole, $4 \%$ estragole and $2 \%$ fenchone.

The main objective of this work was to isolate the essential oil from Macedonian sweet fennel and to identify and quantify its main components using thin-layer chromatography (TLC) and gas chromatography and mass spectrometry (GC-MS). Another issue that is of significance, in terms of quality of the fennel and also of the Aetheroleum Foeniculi, is the auto-oxidation of trans-anethole. There are several proposed intermediates in this process, (epoxyanethole and anethole glycol) and the final product of autooxidation is considered to be $p$-methoxybenzoic acid (Kitajima et al., 1999). We were curious to see if we could observe these compounds in the essential oil. Additionally, as minor objective of this study, was to investigate the reactivity of trans-anethole in oxidation reactions via chemical means, in connection to the mechanism of its autooxidation. 


\section{Material and methods}

\section{General part}

Melting points were determined with Mel-Temp apparatus and were uncorrected. Infrared spectra were measured on a Perkin-Elmer System 2000 FT IR, by the method of $\mathrm{KBr}$ pellets. All the reagents and solvents were obtained from commercial sources and were used without further purification. Thin-layer chromatography was carried out using Merck pre-coated plates $\left(60, \mathrm{GF}_{254}, 250 \mu \mathrm{m}\right)$ and examined under UV light or with sulfuric acid reagent. Preparative flash chromatography (Still et. al. 1978) was performed using Merck silica gel 60 (230-400 mesh). The fruit of sweet fennel (македонски анасон, Foeniculi fructus Series: 010207), methylene chloride, sodium sulfate, potassium permanganate, sodium hydroxide, sodium bisulfite, concentrated sulfuric acid and 37\% hydrochloric acid were obtained from Alkaloid AD Skopje. trans-Anethole, fenchone, estragol and anisaldehyde were obtained from Sigma-Aldrich and tetrabutylammonium chloride was obtained from Fluka. Toluene, hexane, ethyl acetate and 4-methoxybenzoic acid were obtained from Merck.

\section{Gas chromatography}

GC/MS analysis of Aetherloeum Foeniculi was carried out on Agilent Technologies 6890N GC Network system, equipped with 7683B Series injector autosampler and 5975B Inert XL,EI/CI MSD mass spectral detector. GC column: HP-5MS, 30 m x 0.250 mm, 0.25 microns. Temperature programme: starting temperature $70{ }^{\circ} \mathrm{C}(2 \mathrm{~min})$, $15^{\circ} \mathrm{C} / \mathrm{min}$ to $250^{\circ} \mathrm{C}$ (4 min). The MS detection was carried out in the electron impact mode with an ionization energy of $70 \mathrm{eV}$ and with a scan range of 45-400 amu. The carrier gas was helium with a flow rate of $1 \mathrm{~mL} / \mathrm{min}$. The temperature of injector was set at $250{ }^{\circ} \mathrm{C}$, transfer line temperature was set at $240{ }^{\circ} \mathrm{C}$ and the ion source at $250{ }^{\circ} \mathrm{C}$. The chromatograms were analyzed using the MSD Chemstation software package and the mass spectra were compared and matched with both NIST 05 and the Wiley $8^{\text {th }}$ edition registry mass spectral databases (W8/N05). The Aetherloeum Foeniculi was diluted with methylene chloride to give a $0.5 \mathrm{mg} / \mathrm{mL}$ solution of which $1 \mu \mathrm{L}$ was injected in split mode (1:40). For the quantification purposes percent area was reported without correction indices. Portion of one of the isolated essential oils obtained was injected three times and an average of the percent area for the components were calculated.

\section{Isolation of essential oil from Foeniculi fructus}

Freshly ground Foeniculi fructus (10 g) was placed in a $250-\mathrm{mL}$ round-bottom flask, followed by $100 \mathrm{~mL}$ of water and a boiling stone and apparatus for steam distillation was assembled. The mixture was heated until steady distillation began. Water was added occasionally to maintain the original level and the distillate was collected $(\sim 100 \mathrm{~mL})$ until no droplets could be seen. The distillate was extracted with methylene chloride $(3 \times 10 \mathrm{~mL})$ and the combined organic layers were dried over sodium sulfate. Gentle evaporation of the solvents resulted in pale yellow oil with characteristic and pleasant odor. The distillation was repeated three more times giving an average yield of essential oil for the four distillations of $3.2 \%$ by weight from the plant fruits. One sample of the essential oil was used for triplicate TLC and GC-MS analyses. Two of the isolated essential oils were subjected to oxidation and one of the isolated essential oils was used for preparative flash chromatography.

\section{TLC analysis of Aetherloeum Foeniculi}

Portion of one isolated essential oils $(0.1 \mathrm{~mL})$ was dissolved in methylene chloride $(5 \mathrm{~mL})$ and also the available standards were dissolved in methylene chloride and were subjected to the following analyses. The samples were applied onto a Merck silica gel pre-coated plate $\left(60, \mathrm{GF}_{254}\right.$, $250 \mu \mathrm{m}$ ) and developed with 93:7 toluene/ethyl acetate, as a mobile phase over a path of $10 \mathrm{~cm}$. The spots were initially detected with UV light (254 nm) and then with sulfuric acid $\left(140{ }^{\circ} \mathrm{C}\right.$ for 5 minutes). The second solvent system was 5:1 hexane/methylene chloride and the spots were visualized first with UV light (254 nm) and then with sulfuric acid $\left(140{ }^{\circ} \mathrm{C}\right.$ for 5 minutes).

\section{Isolation of trans-anethole from Aetheroleum Foeniculi via Flash chromatography}

The essential oil $(0.30 \mathrm{~g})$ was dissolved in minimal amount of 3:1 mixture of hexane/methylene chloride and applied onto a pre-equilibrated silica gel column. The mixture was eluted with $5: 1(\mathrm{v} / \mathrm{v})$ hexane/methylene chloride. The trans-anethole containing fractions were detected via TLC and combined. Removal of solvent and brief drying in vacuo resulted in $0.162 \mathrm{~g}$ of trans-anethole, 1. mp 19$20{ }^{\circ} \mathrm{C}$ (lit.(Lide, 2003) $20-21^{\circ} \mathrm{C}$ ), $\mathrm{R}_{\mathrm{f}}\left(5: 1\right.$ hexane $/ \mathrm{CH}_{2} \mathrm{Cl}_{2}$ ) $=0.38, \mathrm{R}_{\mathrm{t}}(\mathrm{GC}-\mathrm{MS})=8.03 \mathrm{~min}$, IR (liquid film): 3024, 3003, 2958, 2934, 2914, 2836, 1609, 1577, 1511, 1466, $1455,1441,1306,1284,1247,1175,1036,955,944,840$, 788, $756 \mathrm{~cm}^{-1}$. EI-MS ( $\mathrm{m} / z$, relative intensity): $148\left(\mathrm{M}^{+}\right.$, $100 \%), 147\left(\mathrm{M}^{+}-1,54 \%\right), 133\left(\mathrm{M}^{+}-\mathrm{CH}_{3}, 25 \%\right), 121(18 \%)$, $117\left(\mathrm{M}^{+}-\mathrm{OCH}_{3}, 33 \%\right), 105$ (26\%), 103 (19\%), 91 (17\%), $77(27 \%)$.

\section{Oxidation of Aetheroleum Foeniculi}

The oxidation was performed with a modification of the original procedure described by Garin (1980). To a mixture of potassium permanganate $(0.5 \mathrm{~g})$ in distilled water $(10 \mathrm{~mL})$, seven drops of $10 \%$ solution of tetrabutylammonium chloride and two drops of $10 \%$ sodium hydroxide were added. When the potassium permanganate com- 
pletely dissolved, $0.30 \mathrm{~g}$ of Aetheroleum Foeniculi were added and the mixture was stirred for 5 minutes at ambient temperature and then for 30 minutes on a boiling water bath. As the reaction proceeds, brown precipitate forms and deposits on the walls of the reaction vessel. The reaction mixture was cooled to room temperature and acidified with $6 \mathrm{M}$ hydrochloric acid to a $\mathrm{pH}$ of 2 . Sodium bisulfite was added with stirring until the reaction mixture become clear (no pink color or brown precipitate) and white precipitate remained. The $\mathrm{pH}$ was adjusted to 2 with $6 \mathrm{M}$ hydrochloric acid, the mixture was cooled in an ice bath for 1 hour. The white precipitate was collected via vacuum filtration, washed with ice-cold distilled water and dried. The oxidation was repeated one more time under the same conditions. The average yield of 4-methoxybenzoic acid, 16, from the two reactions was $0.062 \mathrm{~g} . \mathrm{mp} 183-186^{\circ} \mathrm{C}$ (lit. (O'Neal, 2001) mp 184-187 ${ }^{\circ} \mathrm{C}$ ). IR (KBr): 3300-2500 (br. OH stretch), 3029 (aromatic C-H stretch), 2956 (aliphatic C-H stretch), 2941 (aliphatic C-H stretch), 2845, 2729, 2675, 2664, 1688 (C=O stretch), 1608, 1580, 1518, 1429, $1307,1301,1267,1181,1172,1028,929,854,845,825$, $774 \mathrm{~cm}^{-1}$. The isolated trans-anethole (described above) was subjected to the same oxidation conditions and 4-methoxybenzoic acid was obtained.

\section{Results and discussion}

The essential oil of Foeniculi fructus was obtained by steam distillation ( $3.2 \%$ by weight from plant fruit). This value is in agreement with the literature (Dervendji, 1986; Guenther, 1952; Kulevanova, 2004), which gives values ranging from $2 \%$ to $6 \%$ (by weight). The distillation and subsequent extraction are rather simple and can be scaled up without any problems. The most effective and convenient method for rapid qualitative analysis is thin layer chromatography (TLC). We have employed this method for preliminary analysis of the essential oil. The analysis employing silica gel plates, 93:7 toluene/ethyl acetate as mobile phase and UV light visualization resulted in quenching zone in the top of the plate coresponding to trans-anethole $\left(\mathrm{R}_{\mathrm{f}}=0.94\right)$ and a quenching zone in the middle of the plate corresponding to anisaldehyde $\left(\mathrm{R}_{\mathrm{f}}=0.42\right)$. Then the plate was sprayed with sulfuric a trans-anethole and anisaldehyde at once gave red-violet color. A very faint yellow spot for fenchone $\left(\mathrm{R}_{\mathrm{f}} \sim 0.5\right)$ appears when the plate was heated to $140{ }^{\circ} \mathrm{C}$ for 5 minutes. There is a faint reddish-browspot near the solvent front (terpene hydrocarbons). There are several spots in the bottom half of the plate probably corresponding to the more polar components at the origin.

This analysis was not satisfactory for estragol because it had the same $\mathrm{R}_{\mathrm{f}}$ value as the isomeric trans-anethole. It was discovered that the best separation for non-polar components was achieved using 5:1 hexane/methylene chloride as the mobile phase. With this mobile phase transanethole $\left(\mathrm{R}_{\mathrm{f}}=0.38\right)$ can be separated from estragole $\left(\mathrm{R}_{\mathrm{f}}=\right.$ $0.44)$. When the TLC plate was treated with sulfuric acid was heated to $140{ }^{\circ} \mathrm{C}$ for 5 minutes faint reddish-brown zone appeared at $\mathrm{R}_{\mathrm{f}} \sim 0.85$ (terpene hydrocarbons). The separation was satisfactory to the point of employing the mobile phase for preparative separation using flash chromatography. Indeed, trans-anethole was isolated in 54\% yield based on the starting essential oil and characterized.

The method of choice for qualitative and quantitative analysis of complex organic volatile organic mixtures is gas chromatography coupled with mass spectrometry (Adams, 1995). The isolated essential oil was dissolved in methylene chloride and subjected to the GC/MS analysis. The main components of the oil as determined by GC-MS were: trans-anethole, 1, (70\%), $p$-anisaldehyde, 2, (19\%) estragole, $3,(6 \%)$ and anisacetone, $4,(2 \%)$. Minor constituents that were found were limonene, $5,(0.6 \%)$, carvone, 6 , $(0.5 \%)$, fenchone, $7,(0.5 \%)$ and 4-methoxypropiophenone, $8,(0.5 \%)$. The components present in less than $0.4 \%$ were not taken into consideration. The identity of the products was determined by comparison of retention times with available standards and by matching of the obtained mass spectra to the spectra in both Wiley $8^{\text {th }}$ ed. and NIST 2005 libraries (W8/N05). The electron impact mass spectra of the main components (1-4) are given in figures 3 and 4 .

The identity of the main components matched with the data from the literature (Azeez, 2008; Krishna 2004). Based on the reviews of Lawrence (1980) and Maarse $(1989,1991)$ on the quantitative analyses of fennel oils, it can be concluded that the determined content of transanethole $(70 \%)$ in Macedonian sweet fennel oil was within the described range (60-89\%). Also the identity of the other main components is in the agreement with the literature. Our analysis revealed that based on the chemical composition the essential oil from fennel seed showed most similarity to the one reported by Akgül and Bayrak (1988) (75-85\% trans-anethole, $4 \%$ estragole, $2 \%$ fenchone and

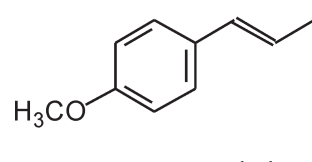

trans-anethole

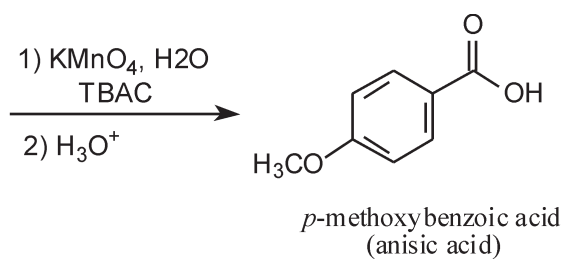

16

Scheme 1. Oxidation of trans-anethole 


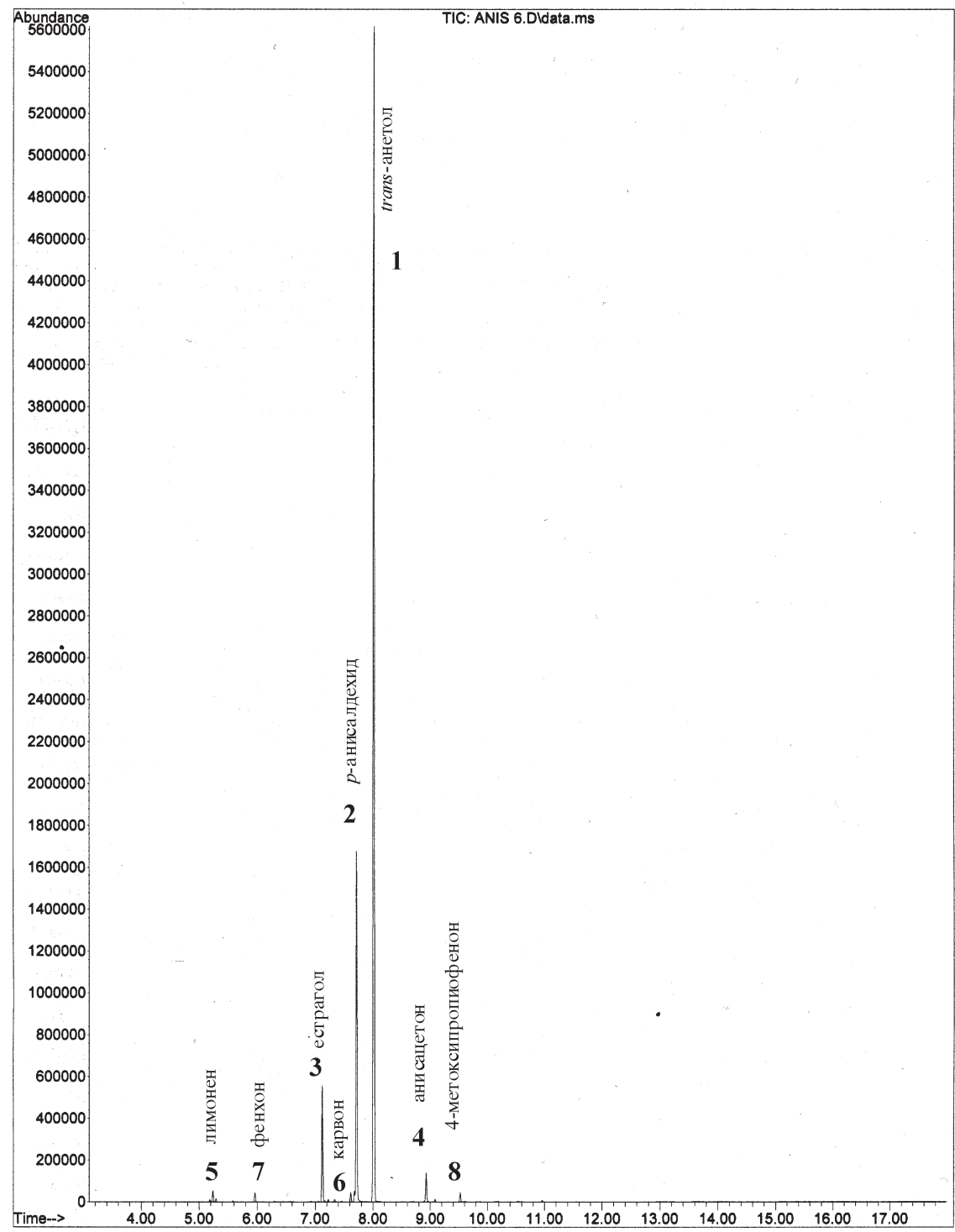

Fig. 2. Gas chromatogram from the analysis of Aetheroleum Foeniculi showing all the major components

Table 1. Key data for the major constituents of the Aetheroleum Foeniculi

\begin{tabular}{|c|c|c|c|c|c|c|}
\hline \multicolumn{2}{|l|}{ Trivial name* } & $\begin{array}{l}\text { CAS reg. } \\
\text { Number }\end{array}$ & $\begin{array}{l}\text { Molecular } \\
\text { formula }\end{array}$ & $\begin{array}{c}\text { Molecular } \\
\text { weight }\end{array}$ & $\begin{array}{c}\mathrm{R}_{\mathrm{t}} \\
(\mathrm{min})\end{array}$ & $\%$ \\
\hline trans-anethole & (1) & {$[4180-23-8]$} & $\mathrm{C}_{10} \mathrm{H}_{12} \mathrm{O}$ & 148.20 & 8.02 & 69.8 \\
\hline$p$-anisaldehyde & (2) & [123-11-5] & $\mathrm{C}_{8} \mathrm{H}_{8} \mathrm{O}_{2}$ & 136.15 & 7.72 & 18.9 \\
\hline estragole & (3) & {$[140-67-0]$} & $\mathrm{C}_{10} \mathrm{H}_{12} \mathrm{O}$ & 148.20 & 7.13 & 5.9 \\
\hline anisacetone & (4) & [122-84-9] & $\mathrm{C}_{10} \mathrm{H}_{12} \mathrm{O}_{2}$ & 164.20 & 8.93 & 1.7 \\
\hline limonene & $(5)$ & {$[138-86-3]$} & $\mathrm{C}_{10} \mathrm{H}_{16}$ & 136.24 & 5.24 & 0.6 \\
\hline carvone & (6) & [99-49-0] & $\mathrm{C}_{10} \mathrm{H}_{14} \mathrm{O}$ & 150.22 & 7.62 & 0.5 \\
\hline fenchone & (7) & {$[1195-79-5]$} & $\mathrm{C}_{10} \mathrm{H}_{16} \mathrm{O}$ & 152.24 & 5.96 & 0.5 \\
\hline 4-methoxypropiophenone & $(8)$ & [121-97-1] & $\mathrm{C}_{10} \mathrm{H}_{12} \mathrm{O}_{2}$ & 164.20 & 9.53 & 0.5 \\
\hline
\end{tabular}

*IUPAC names of the major constituents are: (1) 1-methoxy-4-[(E)-prop-1-enyl]benzene, (2) 4-methoxybenzaldehyde, (3) 1-methoxy-4-(prop-2-enyl) benzene, (4) 1-(4-methoxyphenyl)propan-2-one, (5) 4-isopropenyl-1-methyl-cyclohexene, (6) 5-isopropenyl-2-methyl-cyclohex-2-en-1-one, (7) 1,3,3trimethylbicyclo[2.2.1]heptan-2-one (8) 1-(4-methoxyphenyl)propan-1-one 

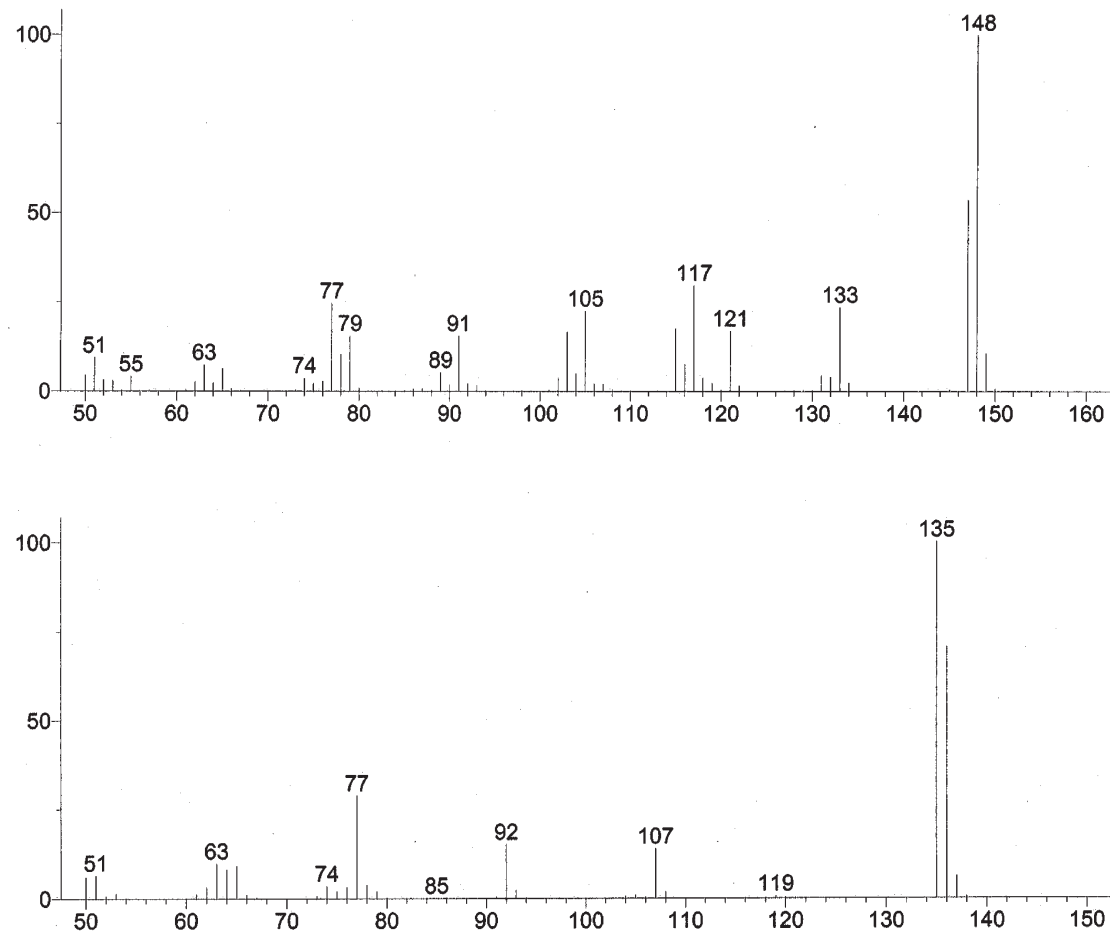

Fig. 3. Electron impact mass spectra of trans-anethole, 1, (top) and p-anisaldehyde, 2, (bottom).
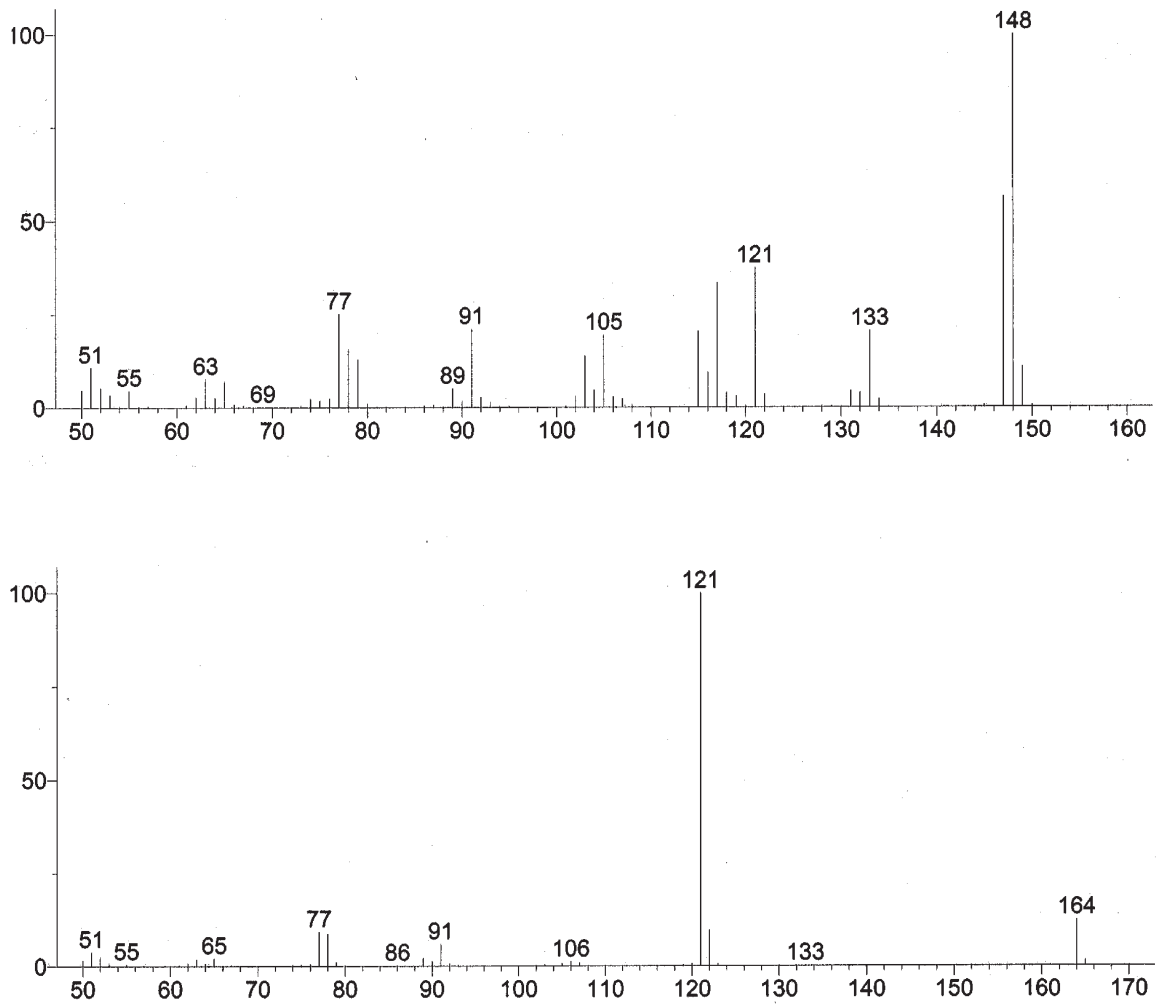

Fig. 4. Electron impact mass spectra of estragole, 3, (top) and anisacetone, 4, (bottom). 
up to $10 \%$ monoterepene hydrocarbons). The differences were that Macedonian sweet fennel was poor in monoterpene hydrocarbons (limonene 7, $\alpha$-pinene $\mathbf{9}$, camphene 12, $\alpha$-phelandrene, 15) compared to the Turkish sweet fennel from Akgül and Bayrak studies (1988), but was rich in anisaldehyde. The relatively high content of trans-anethole $(70 \%)$ and low content of the bitter-tasting fenchone $(0.5 \%)$ of essential oil from this study, ensures sweet fennel oil of high quality.

The identity of the main component, trans-anethole, was confirmed indirectly by potassium permanganate oxidation of the essential oil (Scheme 1). The oxidation product of this reaction, $p$-methoxybenzoic acid, 16, was isolated and characterized by its melting point, mixed melting point with authentic sample and comparison of IR spectra. With this "classical" degradation experiment the position of the double bond and the substitution of the benzene ring in the main component, anethole, was additionally confirmed. It is important to note that under the reaction conditions, the anisaldehyde present will also be oxidized to $p$-methoxybenzoic acid. The yield of $\mathbf{1 6}$ was rather low, but this was not surprising. Alkene oxidative cleavage reactions utilizing potassium permanganate are known to give products in low to moderate yields (McMurry, 2004).

In principle secondary reaction products can be generated if preservation and/or processing of fennel fruit and the essential oil are improperly done. Understanding the mechanisms of these chemical transformations is important in order to maintain the quality and to increase the stability of theses valuable products. Trans-anethole present in the fennel fruit and in the essential oil is susceptible to oxidation, but it is very unlikely that even under improper storage conditions it can be oxidized directly to $\mathbf{1 6}$. This type of alkene oxidative cleavage requires quite powerful oxidizing agents. In the fennel the oxidation of anethole most likely occurs stepwise via several intermediate products (Kitajima et al., 1999). The potential products of autooxidation of trans-anethole (epoxy anethole, anethole glycol and 16) were not detected in freshly obtained essential oils using GC-MS.

\section{Conclusion}

The essential oil of sweet fennel can be easily isolated by distillation and subsequent extraction from the fruits of Foeniculum vulgare Mill. ssp. vulgare var. dulce Batt. and Trab.. Thin layer chromatography provides rapid qualitative analysis of the oil especially for trans-anethole, and anisaldehyde. The complete qualitative and quantitative analysis of the main components was accomplished by GC/MS. The main component, trans-anethole, was isolated from the essential oil using column chromatography. Its identity can be indirectly confirmed by potassium permanganate oxidation of the essential oil. The isolated and characterized 4-methoxybenzoic acid, 16, from this reaction is of significance because it is the final product of the autoox- idation of anethole. The potential products of autooxidation of trans-anethole (epoxy anethole, anethole glycol and 16) were not detected in the freshly obtained essential oils. When it comes to the fennel fruits and the corresponding essential oils, susceptibility of trans-anethole to oxidation has to be taken in consideration and excessive heat (or other) treatment should be avoided. Based on the above-mentioned results (high content of trans-anethole and low content of fenchone) and the absence of intermediate products of autooxidation, it can be concluded that the fennel fruits and the obtained essential oils are of high quality. We plan to investigate in details the mechanism of autooxidation by employing milder oxidizing agents and we are in process of developing alternative methods for detection of the potential autooxidation products.

\section{Acknowledgement}

We would like to thank OPCW and European Union for their generous donation of GC-MS instrument and accompanying accessories.

\section{References}

Adams, R. P., 1995. Identification of Essential Oil Components by Gas Chromatography/Mass Spectroscopy. $1^{\text {st }}$ ed., Allured Publishing Co., Illinois, USA.

Akgul, A., Bayrak, A., 1988. Comparative volatile oil composition of various parts from Turkish bitter fennel (Foeniculum vulgare var. vulgare). Food Chem. 30(4), 319-323.

Azeez, A., 2008. Fennel, in: Parthasarathy, V.A., Chempakam, B., Zachariah, T.J. (Eds.) Chemistry of Spices, CAB International, New Delhi, pp. 227-241.

Dervendji, V., 1986. Prirodni Lekoviti i Aromatični Surovini, $1^{\text {st }}$ ed., Naša Kniga, Skopje, pp.189-191.

European Pharmacopoea (VII) $7^{\text {th }}$ edition, Council of Europe, Strasbourg, 2011.

Garin, D.L., 1980. Steam distillation of essential oils-Anethole from anise followed by permanganate oxidation to anisic acid. J. Chem. Ed. 57, 138-139.

Guenther, E., 1952. The Essential Oils, $6^{\text {th }}$ vol., Van Nostrand, New York, pp. 634-645.

Karlsen, J., Baerheim, S.A., Chingova, B., Zolatovich, G., 1969. Studies on the fruits of Foeniculum species and their essential oil. Planta Med. 1793, 281-293.

Kitajima, J., Ishikawa, T., Tanaka, Y., Ida, Y., 1999. Constituents of fennel. X. New chromanone and phenylethanoid glycosides, and threo-epxyanethole. Chem. Pharm. Bull. 47, 1445-1447.

Kulevanova, S., 2004. Farmakognozija, Kultura, Skopje.

Krishna, A.D., 2004. The genus Foeniculum, in: Jodral, M.M., (Ed.), Illicium, Pimpinella and Foeniculum. CRC Press, Boca Raton, pp. 218-226.

Lawless, J., 1995. The Illustrated Encyclopedia of Essential Oils: The Complete Guide to the Use of Oils in Aromatherapy and Herbalism, $2^{\text {nd }}$ ed., Element Books Ltd., London, pp. 13.

Lawrence, B.M., 1980. New trends in essential oils. Perfumes Flav. 5, 6-16.

Lide, D.R., 2003. CRC Handbook of Chemistry and Physics, CRC Press, Boca Raton, Florida. 
Maarse, H., Visscher, C.A., 1989. Volatile Compounds in FoodQualitative and Quantitative Data, TNO-CIVO Food Analysis Institute, Zeist, The Nederlands.

Maarse, H., 1991. Volatile Compounds in Foods and Beverages, CRC Press Inc., Boca Raton, pp 465-466.

McMurry, J., 2004. Organic chemistry, $6^{\text {th }}$ ed., Brooks/Cole, Pacific Grove, CA, pp. 225-226.

O’Neil, M. J. C. A. M.; Co, Eds. 2001. The Merck Index : An
Encyclopedia of Chemicals, Drugs, and Biologicals; $13^{\text {th }}$ ed. Merck: Whitehouse Station, NJ, USA.

Still, W.C., M. Kahn, M. Mitra, A., 1978. Rapid chromatographic technique for preparative separation with moderate resolution. J. Org. Chem. 43, 2923-2925.

Wiley Registry, $8^{\text {th }}$ edition/NIST 2005, Mass Spectral Library, (W8/N05).

\title{
Резиме
}

\section{TLC и GC-MS анализи на етерично масло изолирано од македонски Foeniculi fructus}

\author{
Менче Најдоска $^{1}$, Јане Богданов ${ }^{1 *}$, Зоран Здравковски ${ }^{1}$ \\ 'Институт за Хемија, Природно-математички факултет, Универзитет „Св. Кирил и Методиј”, Архимедова 5 , \\ МК-1001, Скопје, Република Македонија
}

Клучни зборови: Foeniculum vulgare Mill. ssp.vulgare var. dulce, етерично масло од сладок анасон, хемиски состав, GC-MS, transанетол.

Изолацијата на етерично масло од Foeniculi fructus, зрелиот плод од Foeniculum vulgare Mill. ssp. vulgare var. dulce (aнг. sweet fennel, македонски анасон) беше извршена и главните компоненти беа идентификувани и квантифицирани користејќ тенкослојна хроматографија (TLC) и гасен хроматограф спрегнат со масен спектрометар (GS-MS). Aetherloeum Foeniculi имаше бледо жолта боја и карактеристичен пријатен мирис и беше изолиран во принос од $3,2 \%$ (од масата на плодовите). Главните компоненти на етеричното масло се: trans-анетол 1, (70\%), p-анисалдехид, 2, (19\%) естрагол, 3, (6\%) и анисацетон, 4, (2\%). Идентитетот на компонентите беше одреден преку споредба на добиените масени спектри со спектри од компјутерска библиотека. Идентитетот на главната компонента, trans-анетол, беше потврден директно со изолација со хроматографија во колона и индиректно преку оксидација на етеричното масло со калиум перманганат. Оксидациониот продукт од оваа реакција, $p$-метоксибензоева киселина, 16, беше изолиран и карактеризиран. Потенцијалните продуктите на автооксидацијата на trans-анетол (епоксианетол, анетол гликол и 16) не беа детектирани во свежо добиените етерични масла. 


\title{
Association between CYP2C19*2 variant and clinical outcome in Clopidogrel treated patients from Republic of Macedonia
}

\author{
Aleksandra Kapedanovska Nestorovska ${ }^{1}$, Aleksandra Dimitrovska Cvetkovska ${ }^{2}$, \\ Ljubica Suturkova*1
}

${ }^{1}$ Faculty of Pharmacy, University of Ss Cyril and Methodius, Skopje, R.Macedonia, ${ }^{2}$ Special Hospital for Surgery Diseases "Filip II", Skopje, R.Macedonia

Received: April 2011; Accepted: June 2011

\begin{abstract}
Clopidogrel is the thienopyridine of choice for prevention of ischemic events and stent thrombosis in patients with atherotrombotic disease. Recent studies suggest that certain genetic variants involving CYP450 system are responsible for wide interindividual variability in treatment response profiles among clopidogrel treated individuals. The aim of this study was to define the prevalence of most common CYP2C19*2: 681G>A (rs4244285) allelic variant in Macedonian population and determine the risk association with major cardiovascular adverse events in clopidogrel treated patients with atherotrombotic cardiovascular disease.

CYP2C19 *2 genotype was assessed in 198 subjects from R.Macedonia. The association between the reduced function CYP2C19 *2 A allele and clinical outcome was evaluated in 67 clopidogrel treated patients within a follow up period of at least 6 months (from 6 to 60 months) after initializing clopidogrel therapy.

The population frequency of polymorphic A allele responsible for impaired clopidogrel metabolism in Macedonian population was 0.18 . CYP2C19*2 variant was significantly associated with increased rate of adverse cardiovascular events in the allelic $(\mathrm{OR}=3.188 ; 95 \%$ $\mathrm{CI}=1.437-7.058)$, dominant $(\mathrm{OR}=3.477 ; 95 \% \mathrm{CI}=1.256-9.630)$ and co-dominant model ( $\mathrm{OR}=6.750,95 \% \mathrm{CI}: 1.186-38.410)$ of statistical analysis (adjusted $\mathrm{OR}=2.619 ; \mathrm{P}_{\text {trend }}=0.0088$ ). The influence of $\mathrm{CYP} 2 \mathrm{C} 19 * 2$ was most strongly correlated with worse event free survival in patients carrying AA genotype $(\log$ rank $\mathrm{P}=0.0024)$ and patients carrying at least one $\mathrm{CYP} 2 \mathrm{C} 19 * 2$ reduced function allele $(\log$ rank $\mathrm{P}=0.0058$ ).

CYP2C19*2 genetic variant in the population from Republic of Macedonia has similar distribution as determined in other European populations. Carriage of reduced function CYP2C19*2 allele is associated with worse event free survival in clopidogrel treated patients with atherotrombotic disorders.
\end{abstract}

Key words: clopidogrel, Macedonia, CYP2C19*2, atherotrombotic disease, adverse cardiovascular events, event free survival

\section{Introduction}

Atherosclerotic vascular disease has a predisposition to provoke arterial thrombosis, a sequence that has been called atherotrombotic process. Collectively, atherotrombotic disorders (ATD) of the coronary, cerebrovascular and peripheral arterial circulation are the leading cause of death and disability in the world (Bhatt et al., 2006). Clopidogrel, because of the more favorable safety profile (Bertrand et

* ljsu@ff.ukim.edu.mk al. 2000), is the thienopyridine of choice in prevention of ischemic events and stent thrombosis in patients with ATD and patients undergoing percutaneus coronary intervention (PCI) with or without stenting (Grubel et al., 2003; Steinhbul et al., 2001). It's active thiol metabolite selectively and irreversibly inhibits ADP mediated platelet aggregation by blocking platelet P2Y12 adenosine diphosphate receptors (Grubel and Tantry, 2007). It is mainly used as an adjunctive antithrombotic therapy with aspirin (Yusuf et al., 2001; Sabatine et al., 2005).

Clopidogrel is a prodrug which, after P -glycoprotein mediated absorption, $85 \%$ is metabolized into an inac- 
tive compound and only $15 \%$ undergoes cytochrome P450 (CYP) metabolic oxidation to 2 - oxo clopidogrel which is subsequently hydrolyzed to its highly unstable active thiol metabolite. Accumulating data have shown that there is wide interindividual variability in treatmen response among clopidogrel treated patients (Angiolillo et al., 2007). Several clinical, genetic and cellular factors have been involved in this interindividual response heterogeneity (Geisler et al., 2008).

The most clinically important genetic variants, influencing clopidogrel antiplatelet's effects, are those involving human CYP2C subfamily (Goldstein et al., 2001). Of these, CYP2C19 was shown to be most consistent with the literature data (Mega et al., 2009; Simon et al., 2009), possibly because it contributes in both of the two sequential oxidative metabolic steps of clopidogrel activation (Hulot et al., 2006).

The CYP2C19 contains several Single Nucleotide Polymorphisms (SNP), some of which reduce or abolish the enzymatic activity of CYP2C19 protein and therefore are referred as reduced fnction alleles. In patients who are carriers of a reduced function CYP2C19 allele, the conversion of clopidogrel to its active metabolite may be diminished, resulting in lower amount of active metabolite, decreased inhibition of platelets and higher adverse event rates. According to this, patients are classified into categories of metabolizer phenotypes as "extensive metabolizers" - those with no reduced function allele, "intermediate metabolizers" - those with one reduced function allele and "poor metabolizers"- those with two reduced function alleles, with the use of established common consensus star allele nomenclature (Ingelman-Sundelberg et al., 2007).

Currently the majority of data assessing clopidogrel therapy focuses on the most common allelic variants of CYP2C19 (*2 and *3), which accounts for $95 \%$ of poor metabolizer (PM) phenotypes (Simon et al., 2009). Other more rare alleles causing deficient metabolism are CYP2C19*4, *5, *6, *7, *8, and CYP2C19*17 which on the other hand, results in increased enzyme activity (Dahl and Gunes, 2010).

A number of large scale studies confirmed the prognostic implications of the CYP2C19*2 variant in clopidogrel treated patients. The defining SNP of the CYP2C19*2 haplotype, CYP2C19:681G>A (rs4244285) variant has been associated with increased adverse cardiovascular event (ACE) (stent thrombosis, death, myocardial infarction and stroke) rates, poorer cardiovascular outcomes and attenuated therapy benefits in clopidogrel treated patients (Marin et al., 2009; Shuldiner et al., 2009; Collet et al., 2009; Gladding et al., 2008; Simon et al., 2009, Harmsze et al., 2010). Marked population diversities regarding frequencies of rs4244285 minor A allele has been documented. The prevalence of reduced function (A) allele is approximately 0.15 in Caucasians, 0.17 in African Americans, 0.25 in Chinese and 0.28 in Japanese (Fontana et al., 2007).

The importance of these strong genetic effects was recognized by The Food and Drug Administration which add- ed its strongest warnings to the clopidogrel label, cautioning that certain patients carrying two reduce function alleles cannot metabolize the drug, putting them at increased risk for heart attack and stroke and suggested that those patients need higher dose of clopidogrel or an alternative antiplatelet agent.

The aim of this study was to define the prevalence of most common CYP2C19*2 (rs4244285) allelic variant in population in Macedonian and determine the association between reduced function allele and risk of major ACE in clopidogrel treated patients with atherotrombotic cardiovascular disease (ACD)

\section{Materials and methods}

\section{Patients}

From October 2010 to December 2010, patients presenting at Special Hospital for Surgery Diseases "Filip II", were consequently enrolled in this pharmacogenetic study. All the included subjects were of Caucasian origin. Total number of 198 patient (127 male and 71 female, mean age $60,57 \pm 8,49$ years), were genotyped for CYP2C19*2 polymorphism.

Analysis of clinical outcome in carriers and noncarriers of reduced function CYP2C19*2 A allele was limited to 67 clopidogrel treated patients. Major inclusion criteria was the use of clopidogrel therapy because of established cardiovascular disease (PCI- with or without stent, acute coronary syndrome- ACS, myocardial infarction-MI; coronary artery disease - CAD; coronary artery bypass graft-CABG, peripheral arterial disease-PAD; cerebrovascular disease-CVA), or multiple atherotrombotic risk factors (Type 1 or 2 diabetes, primary hypercholesterolemia, asymptomatic carotid stenosis). The loading dose of clopidogrel during hospitalization was $600 \mathrm{mg}$ per day and the maintenance dose at the time of hospital discharge and therapy period after hospitalization was $75 \mathrm{mg}$ per day.

Patients were excluded if they had 1) prior history of bleeding (e.g. peptic ulcer, intracranial hemorrhage, menstrual bleeding), 2) clinically significant abnormality or abnormal laboratory assessment regarding platelet function before and during follow up study period, 3) concomitant use of other drugs known to modify hepatic drug metabolism, 4) drug addiction or excessive use of alcohol and 5) blood donation within the last 2 months before initialization of clopidogrel therapy. Female patients were not included in the study if they were on hormone replacement therapy or had intra-uterine contraception device.

Clinical outcome was evaluated within a follow up period of at least 6 months (from 6 to 60 months) after initializing clopidogrel therapy. The primary efficacy end point was the first clinical occurrence of any of the following ACE: death, periprocedural myocardial infarction, stent thrombosis, stroke, hospitalization because of unstable angina, transient ischemic attack and re-intervention (revas- 
cularization) during exposure to or after clopidogrel therapy. Follow-up time for Event-Free Survival (EFS) analysis was measured from the date of initializing clopidogrel therapy to the earlier of the first event or last contact alive. Follow-up informations were collected through contacts with the patients' physicians, the patients or their family. All subjects were included in the study after giving informed consent. The study was approved by the Ethics committee of the Faculty of Pharmacy- Skopje.

\section{Genotyping procedures}

Genomic DNA was isolated from peripheral blood using Proteinase $\mathrm{K}$ digestion/phenol-chloroform extraction and ethanol precipitation. Purity was verified by UV absorption at 260/280 nm and DNA integrity was confirmed by electrophoresis in $0,8 \%$ agarose gels, stained with ethidium bromide. The CYP2C19*2 polymorphism [rs4244285] was genotyped by Real-Time PCR [MxPro 3005P, Stratagene, La Jolla, CA, USA] using TaqMan SNP genotyping assay according to the manufacturer instructions [Applied Biosystems, Foster City, CA, USA].

\section{Statistical Analysis}

SISA statistical software package was used to perform Chi-squared analysis and Fishers Exact Test. Odds ratios [OR] were calculated with $95 \%$ confidence limits $[95 \%$ $\mathrm{CI}$. Allele frequencies and allelic distribution were analyzed for Hardy-Weinberg equilibrium.

To examine separate and combined effects of the CYP2C19*2 genotype, certain risk factors (age and gender of the patients, NYHA and APS-CCS status, laboratory data, diabetes mellitus, prior MI, PCI with or without stenting), as well as rate of ACE, stratified analyses were conducted.

Clinical outcome rates (EFS analysis) were made by the Kaplan-Meier method. Differences in survival parameters were assessed for significance by means of the log- rank test. Factors with $\mathrm{p} \leq 0.05$ were considered statistically significant.

\section{Results}

Genotype distributions and allelic frequencies of CYP2C19 *2 genetic variant regarding the two study groups (population group and clopidogrel treated patients) are presented in Table 1 . The population frequency of polymorphic CYP2C19*2 A allele responsible for impaired drug metabolism was 0.18 . The prevalence of subjects homozygous for the wild type allele (GG genotype) was 0.67 , compared to patients heterozygous for the reduced function allele (AG genotype) and homozygous for the reduced function allele (AA genotype), 0.28 and 0.045 , respectively. The observed genotype distributions did not significantly deviate from Hardy-Weinberg equilibrium.

The effect of the CYP2C19*2 variant on clopidogrel treatment outcome was assessed in total of 67 patients. All clopidogrel treated patients, according to the occurrence of ACE with a median of 12 months (range 6 to 60 months) of follow up after initializing the clopidogrel therapy, were randomized in to two patient subgroups. The responders (control) group consisted of 38 (57\%) patients who did not developed any ACE and the non - responders group consisted of 29 (43\%) patients who developed ACE during the follow up period. Demographic and disease characteristics of patients included in the clopidogrel therapy outcome evaluation are summarized in Table 2.

Genotype and allelic frequencies of the control (responders) group were similar to those previously reported for the healthy Caucasian populations. No significant deviations from Hardy-Weinberg equilibrium were observed. The CYP2C19*2 [G/A] genotype frequencies within responders and nonresponder groups were significantly different, owing predominantly to a significant excess of reduced function ' $A$ ' allele homozygotes in the no responders group (Table 3).

Table 1. Genotype distribution and allelic frequencies of CYP2C19 $* 2$ genetic variant in study groups

\begin{tabular}{rcccccc}
\hline \hline & \multicolumn{3}{c}{$\begin{array}{c}\text { Population from R.Macedonia } \\
(\mathrm{N}=198)\end{array}$} & \multicolumn{3}{c}{$\begin{array}{c}\text { Clopidogrel treated patients } \\
(\mathrm{N}=67)\end{array}$} \\
\hline $\begin{array}{r}\text { CYP2C19*2 } \\
\text { polymorphism } \\
{[\text { rs4244285] }}\end{array}$ & $\mathrm{n}$ & $\begin{array}{c}\text { frequencies } \\
(*)\end{array}$ & $\begin{array}{c}\text { expected } \\
\text { frequencies } \\
(*)\end{array}$ & $\mathrm{n}$ & $\begin{array}{c}\text { frequencies } \\
(*)\end{array}$ & $\begin{array}{c}\text { expected } \\
\text { frequencies } \\
(*)\end{array}$ \\
GG & 133 & 67.17 & 66.24 & 39 & 58.2 & 53.29 \\
GA & 56 & 28.28 & 30.39 & 20 & 29.9 & 39.3 \\
AA & 9 & 4.55 & 3.49 & 8 & 11.9 & 7.23 \\
G allele & 322 & 81.31 & & & & \\
A allele & 74 & 18.69 & & 36 & 26.9 & \\
\hline
\end{tabular}


Table 2. Demographic and disease details of the patients monitored for response to clopidogrel therapy

\begin{tabular}{|c|c|c|c|c|c|c|}
\hline Caracteristics & \multicolumn{2}{|c|}{$\begin{array}{c}\text { All patients }(\mathrm{N}=67) \\
\text { n }(\%)\end{array}$} & \multicolumn{2}{|c|}{$\begin{array}{c}\text { Responders }(\mathrm{N}=38) \\
\mathrm{n}(\%)\end{array}$} & \multicolumn{2}{|c|}{$\begin{array}{c}\text { Non responders }(\mathrm{N}=29) \\
\mathrm{n}(\%)\end{array}$} \\
\hline \multicolumn{7}{|l|}{ Gender } \\
\hline Male & 45 & $(67,16)$ & 21 & $(55,26)$ & 24 & $(82,75)$ \\
\hline Female & 22 & $(32,83)$ & 17 & $(44,74)$ & 5 & $(17,25)$ \\
\hline \multicolumn{7}{|l|}{ Age } \\
\hline$>50$ & 13 & $(19,40)$ & 6 & $(15,78)$ & 7 & $(24,13)$ \\
\hline$</=50$ & 54 & $(81,59)$ & 32 & $(84,21)$ & 22 & $(75,87)$ \\
\hline \multicolumn{7}{|l|}{ Diabetes melitus } \\
\hline Yes & 33 & $(49,25)$ & 13 & $(34,21)$ & 20 & $(68,96)$ \\
\hline No & 34 & $(51,75)$ & 25 & $(65,78)$ & 9 & $(31,03)$ \\
\hline \multicolumn{7}{|l|}{ Indication for clopidogrel therapy } \\
\hline $\begin{array}{r}\text { PCI } \\
\text { ( with or without stent) }\end{array}$ & 18 & $(26,86)$ & 13 & $(34,21)$ & 5 & $(17,24)$ \\
\hline MI & 11 & $(16,41)$ & 5 & $(13,15)$ & 6 & $(20,68)$ \\
\hline ACS & 4 & $(5,97)$ & 3 & $(7,89)$ & 1 & $(3,44)$ \\
\hline CAD & 21 & $(31,34)$ & 14 & $(36,84)$ & 7 & $(24,13)$ \\
\hline CABG & 3 & $(4,47)$ & 2 & $(5,26)$ & 1 & $(3,44)$ \\
\hline CVA & 1 & $(1,49)$ & 0 & 0 & 1 & $(3,44)$ \\
\hline PVD & 3 & $(4,47)$ & 0 & 0 & 3 & $(10,34)$ \\
\hline multiple atherotrombotic risk factors & 6 & $(8,95)$ & 1 & $(2,63)$ & 5 & $(17,24)$ \\
\hline
\end{tabular}

Table 3. Risk of adverse cardiovascular events associated with CYP2C19*2 polymorphism [rs4244285] in clopidogrel treated patients from R.Macedonia

\begin{tabular}{|c|c|c|c|c|c|c|c|c|c|}
\hline $\begin{array}{l}\text { Model of } \\
\text { statistical }\end{array}$ & \multicolumn{4}{|c|}{ Responders } & \multicolumn{2}{|c|}{ Non responders } & \multirow[t]{2}{*}{ OR } & \multirow[t]{2}{*}{$95 \% \mathrm{CI}$} & \multirow[t]{2}{*}{$\mathrm{p}$ value } \\
\hline Co- dominant & $\mathrm{n}$ & $\begin{array}{l}\text { Frequencies } \\
(\%)\end{array}$ & $\begin{array}{c}\text { Expected } \\
\text { frequencies (\%) }\end{array}$ & $\mathrm{n}$ & $\begin{array}{l}\text { Frequencies } \\
(\%)\end{array}$ & $\begin{array}{c}\text { Expected } \\
\text { frequencies (\%) }\end{array}$ & & & \\
\hline GG & 27 & 71.05 & 68.70 & 12 & 41.38 & 36.49 & 1.00 & & \\
\hline GA & 9 & 23.68 & 28.36 & 11 & 37.93 & 47.84 & 2.750 & $0.904-8.368$ & 0.07085 \\
\hline $\mathrm{AA}$ & 2 & 5.26 & 2.92 & 6 & 20.69 & 15.72 & 6.750 & $1.186-38.410$ & 0.01906 \\
\hline \multicolumn{10}{|l|}{ Dominant } \\
\hline GG & 27 & 71.05 & & 12 & 41.38 & & 1.00 & & \\
\hline $\mathrm{AA}+\mathrm{GA}$ & 11 & 28.95 & & 17 & 58.62 & & 3.477 & $1.256-9.630$ & 0.01469 \\
\hline \multicolumn{10}{|l|}{ Allelic } \\
\hline G allele & 63 & 82.89 & & 35 & 60.34 & & 1.00 & & \\
\hline A allele & 13 & 17.11 & & 23 & 39.65 & & 3.185 & $1.437-7.058$ & 0.00353 \\
\hline
\end{tabular}

CYP2C19*2 [G/A] variant was associated with increased risk of overall cardiovascular events in the allelic ( $\mathrm{G}$ allele $v s$. A allele), dominant (GG vs. GA+AA) and co-dominant model (GG vs. GA and GG vs. AA) of statistical analysis (adjusted $\mathrm{OR}=2.619 ; \mathrm{P}_{\text {trend }}=0.0088$ ). Allele frequency analysis revealed that the CYP2C19*2 ' $\mathrm{A}$ ' allele carriers had approximately three times higher risk for subsequent adverse cardiovascular events compared to noncarriers $(39.65 \%$ vs. $17.11 \%$; OR $=3.188 ; 95 \% \mathrm{CI}=$ [1.437-7.058], $\mathrm{p}=0.00353)$. This association remained significant also in the dominant model of statistical analysis; $(58.62 \%$ vs. $28.95 \%$; OR $=3.477,95 \% \mathrm{CI}=1.256-9.630$, $\mathrm{p}=0.0147)$. In the co-dominant model of statistical analysis, patients carrying two CYP2C19*2 reduced function al- 
leles, were at even higher risk for adverse cardiovascular events compared to patients homozygotes for CYP2C19*2 wild type allele $(20.69 \%$ vs. $5.26 \%$; OR=6.750, $95 \% \mathrm{CI}$ : $1.186-38.410, \mathrm{p}=0.01906)$. There was no significant association between CYP2C19*2 variant and overall risk of CE regarding the age, gender, different indications for clopidogrel therapy and diabetes mellitus. No significant correlation between CYP2C19*2 variant and specific efficacy end point (ACE) was observed.

A.

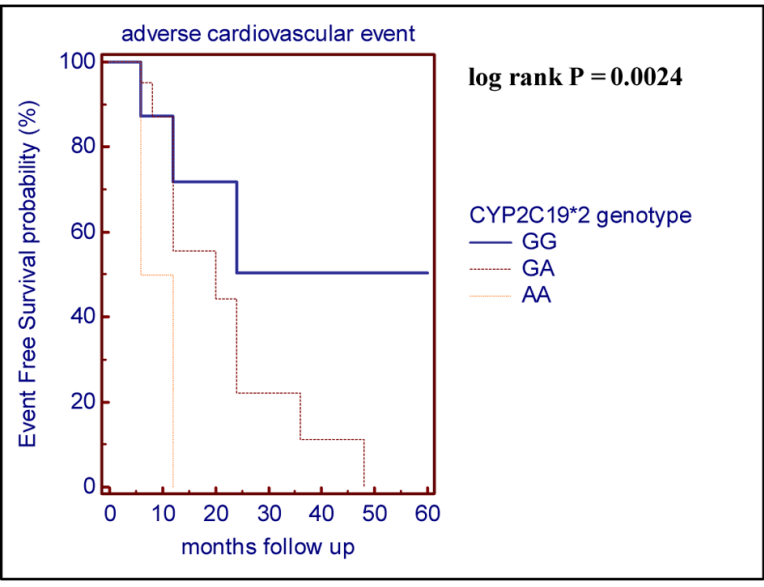

$B$.

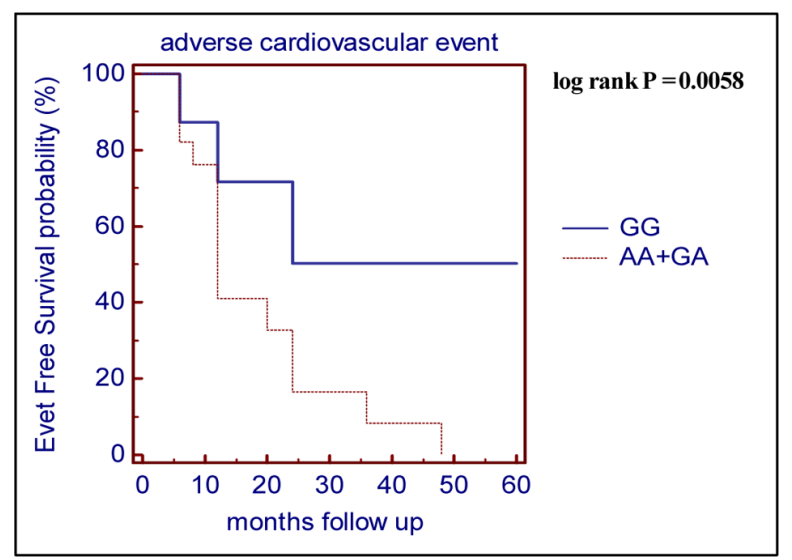

Fig.2. Kaplan Meier Curves show worse EFS for patients: (A) with AA genotype compared to GG and GA genotype patients and (B) carrying at least one CYP2C19*2 reduced function allele (AA+GA genotype vs. GG genotype).

Kaplan-Meier analysis (Fig. 2) confirmed the impact of the CYP2C19*2 genotype on EFS by evidencing a significantly worse therapeutic outcome in patients carrying AA genotype (GG vs. GA vs. AA genotype; log rank $\mathrm{P}=$ $0.0024)$ (Fig. 2A). The adverse impact of CYP2C19*2 reduced function allele on EFS was dramatically increased when carriers of at least one A allele were compared to noncariers (GG vs. GA+AA genotype; $\log$ rank $\mathrm{P}=0.0058$ ) (Fig. 2B). We also tested for interaction between reduced function carrier status and other risk factors (age, gender, prior MI, PCI with or without stenting, CAD, diabetes mel- litus, NYHA) and the time to the first adverse event after initiation of clopidogrel treatment. No significant associations were observed.

\section{Discussion}

This population based case - control study aimed to define the prevalence of the CYP2C19*2 variant in the population in the Republic of Macedonian and determine its influence on the therapeutic outcome in clopidogrel treated patients. The frequency of the most common CYP2C19*2 allelic variant in our population (18\%) was comparable to that found in other European populations: $13.3 \%$ Dutch, 15\% German, 13\% French, 15\% Swedish and 15\% Croatians (Goldstein et al., 1997; Yamada et al., 1998, Bozina et al., 2003). The genotype distributions also corresponded to those for other European white populations. This is the first study which estimates the distribution of the CYP2C19*2 in R.M.

Variability of the interindividual antiplatelet therapy is especially problematic because the therapeutic dose is mostly empirically defined, which can lead to over-antiplatelet effect (overdosing) with potential bleeding complications or underantiplatelet effect (subdosing) with potential thrombotic events. Apart from the small number of clopidogrel treated patients, we confirmed that CYP2C19*2 loss of function allele was significantly associated with 3.18 fold increased risk of developing ACE in our population. The risk for adverse cardiovascular events was even 6.7 fold increased in AA genotype patients - "poor metabolizers", compared to patients carrying GG genotype - "extensive metabolizers". The CYP2C19*2 variant is associated with worse clopidogrel therapy outcome. More important, our results regarding CYP2C19*2 genotype - related therapy outcome showed worse Event Free Survival in "intermediate" and "poor metapolizer" phenotype patients as compared to those classified as "extensive metabolizers" and are in accordance with the results from recently published studies (Pare et al., 2010) for patients followed up to one year. All of the observed ACE were associated with subdosing and occurred while on maintance therapy with $75 \mathrm{mg}$ clopidogrel per day. Absence of the ACE during hospitalization can be explained by the fact that some of the patients during this period of time were on concomitant anticoagulant therapy with unfractioned heparin or low molecular weight heparin. These observations are implying that patient specific response and resistance to clopidogrel does not occur over time and sets the stage for additional studies to determine whether genotype based clopidogrel dose adjustment would increase the plasma levels of active metabolite and overcome interindividual differences in drug response (Grubel et al., 2003).

However, there are some limitations in this study. In this stage of the study we cannot evaluate weather lowering the clopidogrel dose to $75 \mathrm{mg}$ per day after hospitalization period or low compliance to clopidogrel therapy is the 
cause for the subdosing associated adverse effects. Also, we studied only one of the CYP2C19 most common functional alleles. The low allele frequency of other CYP2C19 variants may not alter our conclusion but can be relevant for individual patients.

\section{Conclusion}

The CYP2C19*2 genetic variant in population from Republic of Macedonia has similar distribution as those reported in other European populations. Patients carrying at least one reduced function CYP2C19*2 allele are at increased risk of adverse cardiovascular events associated with suboptimal clopidogrel dosing regimens. Additionally, we have shown that CYP2C19*2 variant is associated with worse event free survival in clopidogrel treated patients. Our study illustrates variable treatment response to the standard maintance dose of clopidogrel and supports further investigations for patient specific individualisation of the clopidogrel treatment protocols in order to improve the clopidogrel therapeutic outcome.

\section{References:}

Angiolillo, DJ., Fernandez-Ortiz, A., Bernardo, E., Alfonso, F., Macaya, C., Bass, TA., Costa, MA., 2007. Variability in individual responsiveness to clopidogrel. Clinical implications, management, and future perspectives. J. Am. Coll. Cardiol. 49, 1505-1516.

Bertrand, ME., Rupprecht, HJ., Urban, P., Gershlick, A.H.; CLASSICS Investigators. Double-blind study of the safety of clopidogrel with and without a loading dose in combination with aspirin compared with ticlopidine in combination with aspirin after coronary stenting: the clopidogrel aspirin stent international cooperative study (CLASSICS)., 2000. Circulation 102(6), 624-629.

Bhatt, D.L., Fox, K.A., Hacke, W., Berger, P.B., Black, H.R., Boden, W.E., Cacoub, P., Cohen, E.A., Creager, M.A., Easton, J.D., Flather, M.D., Haffner, S.M., Hamm, C.W., Hankey, G.J., Johnston, S.C., Mak, K.H., Mas, J.L., Montalescot, G., Pearson, T.A., Steg, P.G., Steinhubl, S.R., Weber, M.A., Brennan, D.M., Fabry-Ribaudo, L., Booth, J., Topol, E.J.; CHARISMA Investigators., 2006. Clopidogrel and Aspirin versus Aspirin Alone for the Prevention of Atherothrombotic Events. N. Engl. J. Med. 354, 1706-1717.

Bozina, N., Granic, P., Lalic, Z., Tramisak, I., Lovric, M., Rukavina, A., 2003. Genetic polymorphisms of Cytochrom P450: CYP2C9, CYP2C19 and CYP2D6 in Croatian population. Croatian Medical Journal 44(4), 425-428.

Collet, J.P., Hulot, J.S., Pena, A., Villard, E., Esteve, J.B., Silvain, J., Payot, L., Brugier, D., Cayla, G., Beygui, F., Bensimon, G., Funck-Brentano, C., Montalescot, G., 2009. Cytochrome P450 2C19 polymorphism in young patients treated with clopidogrel after myocardial infarction: A cohort study. Lancet. 373, 309-317.

Dahl, M.L. and Gunes, A., 2010. Implications of Inter-Individual Differences in Clopidogrel Metabolism, with Focus on Pharmacogenetics. Pharmaceuticals 3, 782-794.

Fontana, P., Hulot, J.S., De Moerloose, P., Gaussem, P., 2007. Influence of CYP2C19 and CYP3A4 gene polymorphisms on clopidogrel responsiveness in healthy subjects. J. Thromb. Haemost. 5, 2153-2155.

Gladding, P., Webster, M., Zeng, I., Farrell, H., Stewart, J., Ruygrok, P., Ormiston, J., El-Jack, S., Armstrong, G., Kay, P., Scott, D., Gunes, A., Dahl ML., 2008. The pharmacogenetics and pharmacodynamics of clopidogrel response: an analysis from the PRINC (Plavix Response in Coronary Intervention) trial. JACC Cardiovasc Interv. 1(6), 620-627.

Geisler, T., Schaeffeler, E., Dippon, J., Winter, E., Buse, V., Bischofs, C., Zuern, C., Moerike, K., Gawaz, M., Schwab, M., 2008. CYP2C19 and nongenetic factors predict poor responsiveness to clopidogrel loading dose after coronary stent implantation. Pharmacogenomics 9, 1251- 1259.

Goldstein, J.A., Ishizaki, T., Chiba, K., De Morais, S.M., Bell, D., Krahn, P.M., Evans, Da., 1997. Frequencies of the defective CYP2C19 alleles responsible for the mephenytoin poor metabolizer phenotype in various Oriental, Caucasian, Saudi Arabian and American black populations. Pharmacogenetics 7, 59-64.

Goldstein J.A., 2001. Clinical relevance of genetic polymorphisms in the human CYP2C subfamily. Br J Clin Pharmacol. 52, 349-355.

Gurbel, P.A., Bliden, K.P., Hiatt, B.L., O’Connor, C.M., 2003. Clopidogrel for Coronary Stenting Response Variability, Drug Resistance, and the Effect of Pretreatment Platelet Reactivity. Circulation. 107, 2908-2913.

Gurbel, P.A., Tantry, U.S., 2007. Clopidogrel resistance? Thromb Res. 120(3), 311-321.

Harmsze, A.M., van Werkum, J.W., Ten Berg, J.M., Zwart, B., Bouman, H.J., Breet, N.J., van 't Hof, A.W., Ruven, H.J., Hackeng, C.M., Klungel, O.H., de Boer, A., Deneer, V.H., 2010. CYP2C19*2 and CYP2C9*3 alleles are associated with stent thrombosis: a case-control study. Eur Heart J. 31(24), 3046-3053.

Hulot, J.S., Bura, A., Villard, E., Azizi, M., Remones, V., Goyenvalle, C., Aiach, M., Lechat, P., Gaussem, P., 2006. Cytochrome P450 2C19 loss-of-function polymorphism is a major determinant of clopidogrel responsiveness in healthy subjects. Blood. 108, 2244-2247.

Ingelman-Sundberg, M., Sim, S.C., Gomez,A., Rodriguez-Antona, C., 2007. Influence of cytochrome $\mathrm{P} 450$ polymorphisms on drug therapies: pharmacogenetic, pharmacoepigenetic and clinical aspects. Pharmacol Ther. 116(3), 496-526.

Marín, F., González-Conejero, R., Capranzano, P., Bass, T.A., Roldán, V., Angiolillo, D.J., 2009. Pharmacogenetics in cardiovascular antithrombotic therapy. J. Am. Coll. Cardiol. 54(12), 1041-1057.

Mega, J.L., Close, S.L., Wiviott, S.D., Shen, L., Hockett, R.D., Brandt, J.T., Walker, J.R., Antman, E.M., Macias, W., Braunwald, E., Sabatine, M.S., 2009. Cytochrome p-450 polymorphisms and response to clopidogrel. N. Engl. J. Med. 360(4), 354-362.

Paré, G., Mehta, S.R., Yusuf, S., Anand, S.S., Connolly, S.J., Hirsh, J., Simonsen, K., Bhatt, D.L., Fox, K.A., Eikelboom, J.W., 2010. Effects of CYP2C19 genotype on outcomes of clopidogrel treatment. N. Engl. J. Med. 363(18), 17041714.

Sabatine, M.S., Cannon, C.P., Gibson, C.M., López-Sendón, J.L., Montalescot, G., Theroux, P., Claeys, M.J., Cools, F., Hill, K.A., Skene, A.M., McCabe, C.H., Braunwald, E.; CLARITY-TIMI 28 Investigators., 2005. Addition of clopidogrel to aspirin and fibrinolytic therapy for myocardial 
infarction with ST-segment elevation. N. Engl. J. Med. 352, 1179-1189.

Shuldiner, A.R., O’Connell, J.R., Bliden, K.P., Gandhi, A., Ryan, K., Horenstein, R.B., Damcott, C.M., Pakyz, R., Tantry, U.S., Gibson, Q., Pollin, T.I., Post, W., Parsa, A., Mitchell, B.D., Faraday, N., Herzog, W., Gurbel, P.A., 2009. Association of cytochrome P450 2C19 genotype with the antiplatelet effect and clinical efficacy of clopidogrel therapy. JAMA. 302(8), 849-857.

Simon, T., Verstuyft, C., Mary-Krause, M., Quteineh, L., Drouet, E., Méneveau, N., Steg, P.G., Ferrières, J., Danchin, N., Becquemont, L.; French Registry of Acute ST-Elevation and Non-ST-Elevation Myocardial Infarction (FAST-MI) Investigators., 2009. Genetic determinants of response to clopidogrel and cardiovascular events. N. Engl. J. Med. 360, $363-375$.

Steinhubl, S.R., Talley, J.D., Braden, G.A., Tcheng, J.E., Casterella, P.J., Moliterno, D.J., Navetta, F.I., Berger, P.B.,
Popma, J.J., Dangas, G., Gallo, R., Sane, D.C., Saucedo, J.F., Jia, G., Lincoff, A.M., Theroux, P., Holmes, D.R., Teirstein, P.S., Kereiakes, D.J., 2001. Point-of-care measured platelet inhibition correlates with a reduced risk of an adverse cardiac event after percutaneous coronary intervention: results of the GOLD (AU-Assessing Ultegra) multicenter study. Circulation. 29; 103(21), 2572-2578.

Yamada, H., Dahl, M., Lannfelt, L., Viitanen, M., Winblad, B., Sjoqvist, F., 1998. CYP2D6 and CYP2C19 genotypes in an elderly Swedish population. Eur. J. Clin. Pharmacol. 54, 479-481.

Yusuf, S., Zhao, F., Mehta, S.R., Chrolavicius, S., Tognoni, G., Fox, K.K., 2001. Clopidogrel in Unstable angina to prevent Recurrent Events trial (CURE) Investigators. Effects of clopidogrel in addition to aspirin in patients with acute coronary syndromes without ST-segment elevation. N. Engl. J. Med. 345, $494-502$.

\title{
Резиме
}

\section{Асоцијација помеѓу СУР2С19*2 полиморфизам и клиничкиот исход од терапија со клопидогрел во Република Македонија}

\author{
Александра Капедановска Несторовска, ${ }^{1}$ Александра Димитровска Цветковска, ${ }^{2}$ \\ Љубица Шутуркова ${ }^{1}$
}

\author{
'Фармацевтски факултет, Универзитет „Св. Кирил и Методиј“- Скопје, Р. Македонија \\ ${ }^{2}$ Специјализирана болница за хирурики болести ,, Филип II“ - Скопје, Р. Македонија.
}

Клучни зборови: клопидогрел, Македонија, СҮР2С19*2, артеротромботски заболувања, несакани кардиоваскуларни настани

Клопидогрелот преставува терапија од избор за спречување на несакани кардиоваскуларни настани (исхемични напади и стент-тромбоза) кај пациетнти со атеротромботична болест и пациенти кои се подложени на перкутана коронарна интервенција, со или без стентирање. Се поголем е бројот на студии кои потврдуваат дека еднонуклеотидните полиморфизми (Single nucleotide polymorphisms-SNP) во гените кои ги кодираат ензимите од CYP 450 суперфамилијата, поточно оние од СҮР2С подфамилијата, се одговорни за клинички значајната интериндивидуална варијабилност во терапискиот исход на пациентите кои се на терапија со клопидогрел.

Целта на ова истражување беше да се одреди фрекфенцијата на застапеност на најчестата СҮР2С19 генетска варијацијаCYP2C19*2: 681G>A (rs4244285) во популација од Р. Македонија и да се утврди асоцијацијата со ризикот за појава на кардиоваскуларни несакани настани кај пациентите кои се на терапија со клопидогрел.

Фрекфенцијата на CYP2C19*2: 681G>A (rs4244285) полиморфизмот во популација од Р.Македонија, беше определена кај вкупно 198 испитаници, додека пак асоцијацијата со ризикот за појава несакани кардиоваскуларни настани и клиничкиот исход од терапијата со клопидогрел беа евалуирани кај вкупно 67 клопидогрел третирани пациенти, следени во период од најмалку 6 месеци (6-60 месеци) по иницијализација на терапијата со клопидогрел.

Фрекфенцијата на полиморфниот СҮР2С19*2 А алел, одговорен за намалениот метаболизам на клопидогрел во популација од Р.Македонија изнесува $18 \%$. Приближно 67\% од популацијата претставуваат “брзи метаболизатори”, $28 \%$ се “умерено брзи “ метаболизатори, додека пак 4.5 \% спаѓаат во групата на “спори” метаболизатори. Утврдена е статистички значајна асоцијација помеѓу CYP2C19*2 полиморфизмот и ризикот за појава на несакани кардиоваскуларни настани $(\mathrm{p}=0.0088)$. Имено, пациентите кои се "спори метаболизатори” имаат за приближно 6 пати поголем ризик за појава на несакани ефекти $(\mathrm{OR}=6.750,95 \% \mathrm{CI}$ : 1.186-38.410) во споредба со пациентите кои се класифицирани како “брзи” метаболизатори на клопидогрел. Генерално, ризикот за појава на несакан кардиоваскуларен настан при терапијата со клопидогрел е за 3 пати поголем кај носителите на само еден алел со редуцирана функција (A алел) споредба со пациентите кои не се носители на алелот со редуцирана функција (OR= 
3.188; 95\% CI= 1.437-7.058). Kaplan - Maier анализата за период на преживување без несакан настан покажа дека влијанието на CYP2C19*2 полиморфизмот е значајно корелирано со помал степен на преживување без несакан настан кај клопидогрел третирани пациентите кои се носители на AA генотипот ( $\log r a n k \mathrm{P}=0.0024)$ во споредба со оние кои се носители на GG или GA генотипот, односно кај пациентите - носители на само еден алел со редуцирана функција $(\log r a n k \mathrm{P}=0.0058)$. Фрекфенцијата на СYР2С19*2 полиморфизмот во популацијата од Р.Македонија е слична со фрекфенцијата на другите Европски популации. CYP2C19*2 полиморфизмот е асоциран со ризик за појава на несакани кардиоваскуларни настани при терапија со стандардни дози на клопидогрел како и со помал степен на преживување без појава на несакан настан кај пациенти со атеротромботични заболувања. 


\title{
Chemical composition of ultrasonic-assisted $n$-hexane extracts of Sideritis scardica Grieseb. and Sideritis raeseri Boiss. \& Heldr. (Lamiaceae) from Macedonia and Albania
}

\author{
Bujar Qazimi, Marija Karapandzova*, Gjose Stefkov, Svetlana Kulevanova \\ Institute of Pharmacognosy, Faculty of Pharmacy, University SS Cyril and Methodius, Skopje, Republic of Macedonia \\ Received: May 2011; Accepted: June 2011
}

\begin{abstract}
Chemical composition of $n$-hexane extracts obtained from dried over-ground parts of two species of Sideritis, S. scardica Grieseb. and S. raeseri Boiss. \& Heldr. (Lamiaceae) was analyzed using GC/FID/MS. The collection of plants was made on different locations in the western part of Macedonia and the southern part of Albania, comprising twelve different samples of plant material. The ultrasonic-assisted extraction process was used for preparation of the $n$-hexane extracts yielded $0.73-3.33 \%$ and $9.11-10.44 \%$ of extracts for $S$. scardica and $S$. raeseri, respectively. Over one hundred constituents of the extracts were identified, belonging to several classes of components: diterpenes, hydrocarbons, dominantly present in each of the extracts, followed by fatty acids, aliphatic and aromatic alcohols, sterols, triterpene alcohols, and monoterpenes and sesquiterpenes, which were found in much smaller amounts or only in traces. The most abundant constituents of the extracts of both species of Sideritis were two diterpene components, both with $\mathrm{M}=286$, which were not fully identified. Large percentages of nonacosane (1.71-12.22\% and 7.46-19.68\% for S. scardica and S. raeseri, respectively) and hentriacontane (4.48-20.79\% and $8.09-30.31 \%$ for $S$. scardica and $S$. raeseri, respectively) were also found in the extracts of both species.
\end{abstract}

Key words: $\quad$ Sideritis scardica, Sideritis raeseri, $n$-hexane extracts, ultrasonic-assisted extraction, composition, GC-MS analysis.

\section{Introduction}

Sideritis scardica Griseb. and Sideritis raeseri Boiss. \& Heldr. (Lamiaceae) are wild, hardy flowering perennials that have adapted to survive with little water and little soil, also known as Mountain tea, Ironwort, Shepard's tea or Pirin tea. Both plants are very popular in Macedonia, Bulgaria, and Greece as well as throughout the Eastern Mediterranean as refreshment but also to cure common cold. The herbs are often used to prepare teas widely believed to alleviate sinus congestion, aches, pains and viruses including flu and common cold. A very aromatic variant of the tea includes combining the Sideritis plant with spices common to the Mediterranean cuisine. Scientists recently suggested that the traditional Greek promotion of mountain tea as a panacea for most illnesses may be remarkably close to the truth.

*Marija_Karapandzova@ff.ukim.edu.mk; marijakarapandzova@yahoo.com
In past decades species of genus Sideritis, especially species from Spain, Turkey, Bulgaria, Albania, Greece, and Serbia, have been extensively investigated on chemical composition of flavonoids, phenilpropanoids, cinnamic acid derivates and phenilethanoids (Palomino et al., 1996; Aboutabl et al., 2002; Ozkan et al., 2005; Erkan et al., 2011; Alipieva et al., 2010; Koleva et al., 2003; Gabrieli et al., 2005, Armata et al., 2008; Pljevljakusic et al., 2011) as well as on essential oils composition, chemistry of diterpeneoids, iridoids and other terpenoids or related components (Gomez-Serranillos et al., 1997; Gomez-Serranillos et al., 2004; Rodriguez-Garcia et al., 2004; Topku et al., 2001; Topku et al., 2002; Alipieva et al., 2009). Recently, data on flavonoids, phenilethanoids and phenilpropanoid acids and their esters have been reported for native Macedonian Sideritis (S. scardica and S. raeseri) (Janeska et al., 2007; Petreska et al., 2011a, 2011b), as well as data on essential oil composition of the same species (Kostadinova et al., 2007). 
In most of the studies conducted on Sideritis, scientists suggested that phenolic and/or polyphenolic components are responsible mostly for the antioxidant activity of alcohol extracts, while terpene components from the essential oils and even more different diterpeneoids are found to be responsible for the anti-inflammatory, analgesic, antiulcer, antibacterial, antifungal, cytotoxic and antitumor activity (Gomez-Serranillos et. al., 2004). Therefore, preparation of an $n$-hexane extracts of dried herbs of Sideritis is the most preferable type of extraction if terpenoid components represent research interest (Alcaraz et al., 1989; Gomez-Serranillos et al., 1998; Gomez-Serranillos et al., 1997; Aboutabl et al., 2002; Menghini et al., 2005; Tsaknis and Lalas, 2005; Kostadinova E. et al., 2008). Usually, the process of extraction is carried out via methods of percolation and maceration, characterized by small efficiency and long drawing (Lysyansky and Grebenyuk, 1987). Nowadays, the use of different electro-physical methods (ultrasound, electro-flotation, etc) allows increasing the extraction rate and yield of biologically active compounds (Sulman et al., 1997; Semagina et al., 2000).

Taking into account the consideration mentioned above, the aim of this work was preparation of $n$-hexane extract of Sideritis scardica and $S$. raeseri by ultrasonic-assistance extraction and determination of the chemical composition of the extracts using GC/FID/MS method.

\section{Experimental}

\subsection{Plant material}

Samples of Sideritis were collected in a flowering stage in the western, central and southern areas in R. Macedonia and southeastern parts of Albania. Sideritis scardica was collected from 7 different regions in Macedonia: Shar Planina (Ljuboten) (V.No. S1/08), Suva Gora (near Gostivar) (V.No. S2/08), Prilep (cultivated plant, V. No. S3/08), Bistra (Lazaropole) (V.No. S4/08), Kozuf (Dve ushi) (V.No. S5/08), Nidze (Kajmakchalan) (V. No. 14/08) and Ilina mountain (S 16/08), while the samples of Sideritis raeseri were collected from Galicica mountain (V. No. 15/08) and Baba mountain (V.No. S6/08) in Macedonia and from Gramoz mountain (V. No. S7/08), Tepelena (V. No. S8/08) and Logora mountain (V. No. S18.08) from south Albania. The collections were made in 2008 and 2009. A voucher specimen of each species was deposited in the Herbarium of the Pharmacognosy Department, Faculty of Pharmacy, University SS Cyril and Methodius, Skopje, Republic of Macedonia. Plant material was left to dry at room temperature and, after draying it was packed in paper bags and left in dark, cool and dry place until analysis.

\subsection{Extraction}

Plant extracts were obtained using ultrasonic-assisted extraction process at room temperature. $n$-Hexane was used for the extraction in 2 portions in ratio to plant material 1:20 (1 g plant material was extracted twice with $10 \mathrm{ml}$ solvent). The duration of the extraction was $2 \times 30$ minutes. The extracts obtained after filtration were concentrated to dryness below $35^{\circ} \mathrm{C}$. The residue were measured as yield of the extraction and then dissolved in $n$-hexane to obtained solution with concentration of $1 \mathrm{~g}$ plant material in $1 \mathrm{ml}$ solution. For GC/FID/MS analysis additional $1 \mu \mathrm{g} / \mathrm{ml}$ dilutions were prepared.

\subsection{Gas chromatography}

$n$-Hexane extracts were analyzed on Agilent 7890A Gas Chromatography system equipped with FID detector and HP-5ms 5\% phenyl 95\% dimethylpolysiloxane bonded phase capillary column (30 m x $0.25 \mathrm{~mm}$, film thickness $0.25 \mu \mathrm{m})$. Operating conditions were as follows: oven temperature at $60^{\circ} \mathrm{C}$ for $5 \mathrm{~min}$, then increased to $80^{\circ} \mathrm{C}$ at rate of $1^{\circ} \mathrm{C} / \mathrm{min}$ and held $2 \mathrm{~min}$ and at the end increased to $280^{\circ} \mathrm{C}$ at rate of $5^{\circ} \mathrm{C} / \mathrm{min}$ and held $5 \mathrm{~min}$; helium as carrier gas at a flow rate of $1 \mathrm{ml} / \mathrm{min}$; temperature of the injector $260^{\circ} \mathrm{C}$ and that of the FID detector $270^{\circ} \mathrm{C}$; the GC split ratio $1: 1$. $1 \mu \mathrm{l}$ of each sample of the essential oil, dissolved in xylene (1: $1000 \mathrm{v} / \mathrm{v}$ ) was injected per GC run.

The percentage composition of $n$-hexane extracts were computed by the normalization method from the GC/FID peak areas (relative amount of each compound to the total amount present), calculated by means of three injections from each extract.

The extracts were analyzed on Agilent 7890A Gas Chromatography system interfaced to an Agilent 5975C mass spectrometer. The gas chromatographic conditions were the same as reported for GC analysis and the same column was used. The mass spectrometry conditions were: ionization voltage $70 \mathrm{eV}$, ion source temperature $230^{\circ} \mathrm{C}$ and mass range from 50 - $500 \mathrm{Da}$

Identification of the components present in essential oils was made by comparing mass spectra of components in essential oils with those from Nist, Wiley and Adams mass spectra libraries, by AMDIS (Automated Mass Spectral Deconvolution and Identification System) and by comparing literature and estimated Kovat's (retention) indices that were determined using mixture of homologous series of normal alkanes from $\mathrm{C}_{9}$ to $\mathrm{C}_{25}$ in hexane, under the same above mentioned conditions.

\section{Results and discussion}

The ultrasonic-assisted extraction yielded different amount of dry extracts (dry residues after evaporation) ranged from $0.73-3.33 \%$ for the samples of $S$. scardica and from $9.11-10.44 \%$ for the samples of $S$. raeseri (Table 1.). The yields of $n$-hexane extracts of $S$. raeser $i$ were almost the same for different samples of the plant regardless of the collection site. In the case of $S$. scardica much more variations in the extraction yields appeared. The higher yield of 
Table 1. The yields of $n$-hexane extracts of Sideritis obtained by ultrasonic-assisted extraction

\begin{tabular}{lclc}
\hline \hline \multicolumn{1}{c}{ S. scardica } & $n$-hexane extr. (\%) & \multicolumn{1}{c}{ S. raeseri } & $n$-heksane extr. (\%) \\
\hline Shar Planina (Ljuboten) & 0.73 & Baba mountain. & 9.11 \\
Suva Gora (Gostivar) & 0.89 & Galicica mountain & 9.87 \\
Prilep (cultivated) & 1.78 & Gramoz mountain (Albania) & 10.44 \\
Bistra (Lazaropole) & 3.33 & Tepelena (Albania) & 9.53 \\
Kozuf (Dve ushi) & 0.82 & Logora mountain (Albania) & 9.34 \\
Nidze (Kajmakcalan) & 1.23 & & \\
Ilina mountain & 1.52 & & \\
\hline
\end{tabular}

$(\mathrm{n}=3)$

$n$-hexane extract for $S$. raeseri against $S$. scardica, probably due to the larger amounts of components extractible in hexane in $S$. raeseri. Bulgarian scientists reported 0.50 $0.58 \%$ yields of the $n$-hexane extracts for both species, $S$. scardica and $S$. raeseri, which is significantly lower from our findings (Kostadinova et al., 2008). The reason of lower yield probably lays in the differences in geographical origin of the samples, but it is worth mentioning that those scientists have used $24 \mathrm{~h}$ maceration as extraction procedure while in our case it was ultrasonic-assisted extraction. According to literature data, ultrasonic-assisted extraction has been pointed out as more effective extraction procedure (Sulman et al., 1997, Samagina et al., 2000).

Gas-chromatography analysis showed presence of over 100 individual components identified by GC/MS. The results of chemical composition of $n$-hexane extract of $S$. scardica are presented in Table 2 and for $S$. raeseri in Table 3 . The chemical composition of the $n$-hexane extracts of both species showed qualitative and quantitative similarities. Mono and sesquiterpenes were presented in very small amounts, almost in traces, but apart from that, 25 components were identified. In S. scardica the sesquiterpene: trans-caryophyllene, $\delta$-cadinene, caryophyllene oxide and $\alpha$-cadinol $+\tau$ muurolol denoted the main part of this fraction. In $S$. raeseri additionaly $\alpha$ - and $\beta$-pinenes, myrtenol, trans-cadina-1,4diene, viridiflorol, valeranone and $\alpha$-bisabolole were found. These data differ a lot from the previously reported data of chemical composition of essential oils of S. scardica (Galicnik) and $S$. raeseri (Galicica) from Macedonia (Kostadinova et. al., 2007). For both species, $\alpha$-cadinol was defined as the dominant component and elemol acetate and germacron additionaly for the $S$. raeseri. Interesting results for the chemical composition of essential oils of cultivated $S$. raeseri subsp. raeseri were recently reported for the plant cultivated in Serbia. The main mono and sesquiterpene components of those oils were bicyclogermacrene and spatulenol (Plevljakisic et al., 2011). In both cases essential oils were obtained by hydro-distillation and besides mono and sesquiterpenes contained fatty acids and their esters, hydrocarbons and several diterpenes. All these components were also found in $n$ hexane extracts of our specimens of Sideritis.
The fractions of fatty acids and fatty acid-ester compounds were found in larger amount than fractions of mono and sesqiterpenes. Within these fractions, the main components were methyl, isopropyl hexadecanoate and hexadecanoic acid in S. scardica as well as octadecanoic acid methyl ester and hexadecanoic acid in $S$. raeseri. Large fraction of the $n$-hexane extracts belonged to hydrocarbons comprising aliphatic components with long carbon-chains (C5-C33). The hydrocarbons represented 13.33-47.24\% of $n$-hexane extract of S. scardica (Fig. 1) and 26.24-68.12\% of $n$-hexane extracts of $S$. raeseri (Fig. 2). The most abundant components were heptacosane, nonacosane, hentriacontane and tritriacontane. Among them, hentriacontane was the predominant hydrocarbon in the extracts of both species, with 4.48-20.79 \% in S. scardica and 8.09-30.31 in $S$. raeseri. Very small part of extracts contained oxidized products of hydrocarbons such as different alcohols, rarely some esters. Kostadinova et al. (2008) in $n$-hexane extracts of $S$. scardica and $S$. scardica $x$ S. syriaca hybride also found nonacosane and hentriacontane as predominant hydrocarbons. Seasonal variation in the content of some hydrocarbons, mainly hentriacontane and nonacosane, was found for both species (Table 2 and 3 ).

Besides hydrocarbons, second predominant fraction, of the $n$-hexane extracts of the investigated species of Sideritis, were diterpeneoids. This fraction represented 23.00-60.80\% of the S. scardica (Fig. 1) and 22.13$45.44 \%$ of the $S$. raeseri $n$-hexane extracts (Fig. 2). $(+)$-Beyeren, pimara-8(14),15-diene, kaur-15-en, 7-ethenyl-1,2,3,4,4a,4b,5,6,7,9,10,10a-dodecahydro-1,1,4a,7tetramethyl-2-phenanthrenol and manyol oxide were identified an in addition eight more components were tentatively indetified as diterpeneoids. We were unable to identify the two dominant components in this fraction (in some cases the most dominant components in the whole extract). These components, both with $\mathrm{M}=286$, are probably pimarane derivates. Besides them, there were three diterpenee components with $\mathrm{M}=306, \mathrm{M}=346$ and $\mathrm{M}=286$, also not identified. Few of them were probably components with kaurane skeleton, as kauranes were often identified until now in different species of Sideritis as the predominant 
Table 2. Chemical composition of hexane extracts of Sideritis scardica from different location from Macedonia

\begin{tabular}{|c|c|c|c|c|c|c|c|c|c|c|c|c|}
\hline Components & KIE & \multicolumn{2}{|c|}{$\begin{array}{l}\text { Shar Planina } \\
20082009\end{array}$} & \multicolumn{2}{|c|}{$\begin{array}{l}\text { Suva Gora } \\
20082009\end{array}$} & \multicolumn{2}{|c|}{$\begin{array}{l}\text { Prilepsko** } \\
20082009\end{array}$} & \multicolumn{2}{|c|}{$\begin{array}{c}\text { Bistra } \\
20082009\end{array}$} & \multirow[t]{2}{*}{$\begin{array}{l}\text { Kozuf } \\
2008\end{array}$} & \multirow[t]{2}{*}{$\begin{array}{l}\text { Nidze } \\
2008\end{array}$} & \multirow[t]{2}{*}{$\begin{array}{c}\text { Ilina Mtn. } \\
2008\end{array}$} \\
\hline $\begin{array}{l}\text { MONO and } \\
\text { SESQUITERPENS }\end{array}$ & & & & & & & & & & & & \\
\hline$\alpha$-Pinene & 951.1 & $\operatorname{tr}$ & $\operatorname{tr}$ & - & - & - & - & 0.01 & - & - & $\operatorname{tr}$ & - \\
\hline Camphene & 960.7 & - & - & - & - & - & - & 0.01 & - & - & - & - \\
\hline$\beta$-Pinene & 980.8 & $\operatorname{tr}$ & - & - & - & - & - & 0.01 & - & - & - & - \\
\hline$\beta$-Myrcene & 992.6 & - & - & - & - & - & - & 0.01 & - & - & - & - \\
\hline $\begin{array}{l}\text { D-Limonene }+ \\
\beta \text {-Phellandren }\end{array}$ & 1024.2 & $\operatorname{tr}$ & $\operatorname{tr}$ & $\operatorname{tr}$ & $\operatorname{tr}$ & - & - & 0.02 & $\operatorname{tr}$ & $\operatorname{tr}$ & $\operatorname{tr}$ & $\operatorname{tr}$ \\
\hline trans-Pinocarveole & 1145.1 & $\operatorname{tr}$ & - & $\operatorname{tr}$ & $\operatorname{tr}$ & $\operatorname{tr}$ & $\operatorname{tr}$ & - & - & - & - & - \\
\hline trans-Sabinol & 1152.9 & $\operatorname{tr}$ & - & $\operatorname{tr}$ & $\operatorname{tr}$ & $\operatorname{tr}$ & - & - & - & - & $\operatorname{tr}$ & \\
\hline Myrtenol & 1212.9 & 0.05 & 0.02 & $\operatorname{tr}$ & $\operatorname{tr}$ & $\operatorname{tr}$ & $\operatorname{tr}$ & 0.01 & $\operatorname{tr}$ & $\operatorname{tr}$ & $\operatorname{tr}$ & $\operatorname{tr}$ \\
\hline (-)-Verbenone & 1231.5 & $\operatorname{tr}$ & - & $\operatorname{tr}$ & $\operatorname{tr}$ & 0.06 & $\operatorname{tr}$ & 0.01 & $\operatorname{tr}$ & - & $\operatorname{tr}$ & - \\
\hline$\alpha$-Cubebene & 1403.6 & 0.02 & & - & $\operatorname{tr}$ & $\operatorname{tr}$ & - & - & - & - & $\operatorname{tr}$ & - \\
\hline$\alpha$-Copaene & 1437.4 & - & 0.01 & $\operatorname{tr}$ & $\operatorname{tr}$ & $\operatorname{tr}$ & - & - & 0.05 & $\operatorname{tr}$ & 0.07 & 0.05 \\
\hline $\begin{array}{l}\text { Muurola-4(14),15-diene } \\
\text { (cis) }\end{array}$ & 1454.2 & 0.03 & - & - & - & - & - & - & - & - & - & - \\
\hline trans-Caryophyllene & 1488.7 & 0.09 & 0.10 & 0.14 & 0.26 & 0.05 & 0.08 & 0.01 & 0.07 & 0.30 & 0.31 & 0.08 \\
\hline Muurola-3,5-diene (trans) & 1524.7 & - & - & $\operatorname{tr}$ & $\operatorname{tr}$ & $\operatorname{tr}$ & - & - & - & - & - & - \\
\hline$\alpha$-Hummulene & 1528.9 & 0.01 & - & - & - & - & - & - & $\operatorname{tr}$ & 0.07 & 0.05 & - \\
\hline Germacren D & 1560.7 & 0.03 & 0.01 & - & - & - & - & 0.01 & $\operatorname{tr}$ & 0.04 & 0.05 & 0.08 \\
\hline Bicyclogermacrene & 1578.1 & 0.03 & 0.01 & - & - & - & - & - & - & - & - & - \\
\hline$\delta$-Cadinene & 1606.4 & 0.05 & 0.02 & - & - & - & - & $\operatorname{tr}$ & 0.08 & - & 0.15 & 0.03 \\
\hline Cadina-1,4-diene (trans) & 1617.3 & 0.04 & 0.02 & - & - & 0.06 & - & $\operatorname{tr}$ & - & - & 0.04 & 0.05 \\
\hline (-)-Spatulenol & 1669.8 & 0.05 & 0.02 & & & - & - & $\operatorname{tr}$ & - & 0.04 & 0.04 & - \\
\hline Caryophyllene oxide & 1677.0 & 0.12 & 0.10 & 0.13 & 0.12 & - & 0.11 & - & 0.04 & 0.05 & 0.12 & 0.07 \\
\hline Viridiflorol & 1686.1 & 0.03 & 0.01 & - & - & - & - & - & 0.05 & - & - & - \\
\hline $\begin{array}{l}\alpha \text {-Cadinol }+ \\
\tau-\text { Muurolol }\end{array}$ & $\begin{array}{l}1739.1 \\
1739.5\end{array}$ & 0.07 & 0.05 & - & - & - & - & - & 0.30 & 0.04 & 0.03 & 0.05 \\
\hline Valeranone & 1775.4 & - & 0.03 & - & - & - & - & $\operatorname{tr}$ & $\operatorname{tr}$ & - & - & 0.03 \\
\hline $\begin{array}{l}\text { Total mono- and } \\
\text { sesquiterpens: }\end{array}$ & & 0.71 & 0.43 & 0.35 & 0.47 & 0.30 & 0.22 & 0.21 & 0.67 & 0.57 & 0.95 & 0.49 \\
\hline \multicolumn{13}{|l|}{ DITERPENS } \\
\hline$(+)$-Beyerene & 2056.7 & 0.07 & 0.05 & - & - & 0.06 & - & 0.01 & $\operatorname{tr}$ & - & - & - \\
\hline Pimara-8(14),15-diene & 2072.4 & 0.07 & 0.05 & - & - & - & - & $\operatorname{tr}$ & - & - & - & - \\
\hline Kaur-15-en & 2126.0 & 0.10 & 0.08 & - & & 0.16 & - & 0.05 & 0.07 & 0.05 & - & - \\
\hline Manoyl oxide & 2146.2 & 0.04 & 0.02 & - & & - & - & - & $\operatorname{tr}$ & - & - & - \\
\hline $\begin{array}{l}\text { 3 } \alpha \text {-Hydroxymanool } \\
(\mathrm{M}=288)^{*}\end{array}$ & 2327.3 & 0.22 & 0.20 & 0.24 & 0.09 & 0.23 & 0.21 & 0.08 & 0.29 & 0.08 & 0.06 & 0.06 \\
\hline 7-ethenyl- & 2335.8 & 0.26 & 0.24 & 0.23 & 0.24 & 0.23 & 0.13 & 0.08 & 0.18 & 0.13 & 0.10 & 0.15 \\
\hline
\end{tabular}




\begin{tabular}{|c|c|c|c|c|c|c|c|c|c|c|c|c|}
\hline Components & KIE & $\begin{array}{c}\text { Shar P } \\
2008\end{array}$ & $\begin{array}{l}\text { lanina } \\
2009\end{array}$ & $\begin{array}{l}\text { Suva } \\
2008\end{array}$ & $\begin{array}{l}\text { Gora } \\
2009\end{array}$ & $\begin{array}{l}\text { Prileps } \\
2008\end{array}$ & $\begin{array}{l}\text { sko** } \\
2009\end{array}$ & $\begin{aligned} & \text { Bis } \\
& 2008\end{aligned}$ & $\begin{array}{l}\operatorname{tra} \\
2009\end{array}$ & $\begin{array}{c}\text { Kozuf } \\
2008\end{array}$ & $\begin{array}{l}\text { Nidze } \\
2008\end{array}$ & $\begin{array}{l}\text { Ilina Mtn. } \\
2008\end{array}$ \\
\hline Diterpene $(\mathrm{M}=306)$ & 2374.2 & 0.22 & 0.19 & 0.12 & 0.13 & 0.19 & - & 0.07 & 0.09 & 0.07 & - & 0.10 \\
\hline Diterpene $(\mathrm{M}=306)$ & 2388.5 & - & - & - & - & 0.24 & - & 0.06 & 0.19 & 0.15 & 0.04 & 0.12 \\
\hline Diterpene $(\mathrm{M}=306)$ & 2458.8 & 0.64 & 0.62 & 0.28 & 0.22 & 0.76 & 0.28 & 0.25 & 0.44 & 0.46 & 0.23 & 0.14 \\
\hline Diterpene $(\mathrm{M}=286)^{*}$ & 2487.7 & & 10.49 & 6.70 & 7.78 & 13.14 & 6.11 & 8.72 & 12.65 & 8.52 & 4.15 & 4.68 \\
\hline Diterpene $(\mathrm{M}=286)^{*}$ & & & 37.12 & 24.08 & 28.25 & 42.43 & 19.92 & 15.86 & 31.15 & 28.66 & 20.00 & 17.04 \\
\hline Diterpene $(\mathrm{M}=346)$ * & - & - & 1.32 & - & 0.92 & - & 0.89 & 0.67 & 0.30 & 0.92 & 0.55 & 0.59 \\
\hline Diterpen $(\mathrm{M}=286) *$ & - & - & - & 0.74 & 1.86 & 3.59 & 1.50 & 1.13 & 2.23 & 2.02 & 1.47 & 0.11 \\
\hline Total diterpens: & & & 50.38 & 32.31 & 39.49 & 61.03 & 29.04 & 38.04 & 47.61 & 41.06 & 27.50 & 23.15 \\
\hline ESTERS & & & & & & & & & & & & \\
\hline Benzyl benzoate & 1924.3 & 0.05 & 0.02 & - & - & - & 0.05 & $\operatorname{tr}$ & 0.04 & - & - & - \\
\hline Isopropyl tetradecanoate & 1978.5 & 0.05 & 0.03 & 0.08 & - & 0.04 & 0.11 & - & 0.08 & 0.06 & 0.25 & 0.32 \\
\hline Di-isobutyl phthalate* & 2029.2 & 0.05 & 0.01 & - & - & - & 0.09 & $\operatorname{tr}$ & 0.07 & - & - & - \\
\hline Methyl hexadecanoate & 2103.3 & 0.05 & 0.03 & - & - & - & 0.11 & 0.01 & 0.06 & 0.04 & - & - \\
\hline $\begin{array}{l}\text { Hexadecanoic acid } \\
\text { ethylester }\end{array}$ & 2135.6 & - & - & - & & 0.06 & - & 0.03 & 0.07 & - & - & - \\
\hline Isopropyl hexadecanoate & 2243.4 & - & 0.03 & - & - & - & - & - & 0.04 & - & - & - \\
\hline Methyl octadecanoate* & & - & 0.10 & 0.10 & 0.14 & - & 0.12 & 0.04 & 0.05 & - & - & - \\
\hline $\begin{array}{l}\text { 9,12-Octadienoic acid } \\
\text { ethylester* }\end{array}$ & & - & - & - & - & - & - & - & 0.10 & 0.15 & 0.10 & 0.15 \\
\hline Total esters: & & 0.20 & 0.22 & 0.18 & 0.14 & 0.10 & 0.48 & 0.14 & 0.52 & 0.25 & 0.35 & 0.47 \\
\hline $\begin{array}{l}\text { HYDROCARBONS } \\
\text { Heptadecane }\end{array}$ & 1790.5 & 0.05 & 0.01 & - & 0.10 & - & - & 0.22 & 0.03 & 0.05 & - & - \\
\hline Octadecane & 1896.4 & $\operatorname{tr}$ & 0.01 & - & - & - & - & - & 0.02 & - & - & - \\
\hline Nonadecane & 2002.0 & 0.03 & 0.01 & - & - & - & - & 0.03 & 0.04 & 0.04 & 0.05 & - \\
\hline Eicosane & 2108.2 & 0.06 & 0.04 & - & - & - & 0.13 & - & 0.03 & - & 0.03 & 0.03 \\
\hline Heneicosane & 2213.4 & 0.07 & 0.05 & - & - & - & 0.09 & $\operatorname{tr}$ & 0.06 & 0.04 & 0.06 & 0.06 \\
\hline Docosane & 2318.5 & 0.16 & 0.14 & - & - & 0.05 & 0.18 & - & 0.08 & - & 0.15 & 0.10 \\
\hline Tricosane & 2423.2 & 0.27 & 0.25 & 0.57 & 0.39 & 0.38 & 0.32 & 0.11 & 0.35 & 0.26 & 0.59 & 0.31 \\
\hline Tetracosane & 2528.7 & 0.07 & 0.05 & 0.14 & 0.10 & 0.16 & 0.36 & 0.04 & 0.41 & 0.10 & 0.18 & 0.09 \\
\hline Pentacosane & 2631.0 & 0.36 & 0.34 & 0.82 & 0.64 & 0.80 & 0.82 & 0.20 & 0.90 & 0.79 & 1.47 & 0.84 \\
\hline Hexacosane & 2691.5 & - & 0.07 & - & - & - & 0.09 & - & 0.12 & - & 0.04 & 0.07 \\
\hline Heptacosane & 2784.4 & 1.66 & 1.62 & 3.17 & 2.73 & 1.68 & 3.12 & 0.47 & 2.19 & 2.17 & 4.10 & 3.86 \\
\hline Octacosen* & 2810.3 & - & 0.27 & - & 0.44 & 0.56 & 0.68 & 0.08 & 0.48 & 0.18 & 0.55 & 0.18 \\
\hline Octacosane & 2822.2 & 0.30 & 0.28 & 0.46 & 0.49 & 0.50 & 0.72 & 0.11 & 0.72 & 0.52 & 0.61 & 0.52 \\
\hline Nonacosane & 3024.6 & 7.42 & 7.41 & 12.22 & 10.41 & 3.48 & 11.01 & 1.71 & 7.20 & 9.59 & 0.13 & 8.59 \\
\hline Triacontane & 3025.1 & 0.26 & 0.24 & 0.83 & 0.68 & 0.16 & 0.79 & 0.18 & 0.75 & 0.87 & 1.08 & 1.05 \\
\hline Hentriacontane & 3132.3 & & 12.30 & 20.79 & 16.72 & 4.48 & 17.92 & 13.36 & 12.0 & 18.63 & 9.96 & 18.13 \\
\hline Dotriacontane* & & 0.50 & 0.47 & 0.93 & 0.79 & 0.07 & 0.60 & 0.14 & 0.46 & 1.19 & 1.04 & 1.19 \\
\hline Tritriacontane * & & 2.00 & 3.14 & 7.38 & 5.97 & 1.01 & 5.30 & 1.43 & 3.66 & 5.78 & 7.85 & 6.78 \\
\hline Total hydrocarbons: & & & 26.61 & 47.24 & 39.34 & 13.33 & 42.13 & 18.09 & 26.50 & 40.21 & 48.27 & 26.55 \\
\hline
\end{tabular}




\begin{tabular}{|c|c|c|c|c|c|c|c|c|c|c|c|c|}
\hline \multirow[b]{2}{*}{ FATTY ACIDS } & \multirow[t]{2}{*}{ KIE } & \multicolumn{2}{|c|}{$\begin{array}{l}\text { Shar Planina } \\
20082009\end{array}$} & \multicolumn{2}{|c|}{$\begin{array}{l}\text { Suva Gora } \\
20082009\end{array}$} & \multicolumn{2}{|c|}{$\begin{array}{l}\text { Prilepsko** } \\
20082009\end{array}$} & \multicolumn{2}{|c|}{$\begin{array}{c}\text { Bistra } \\
20082009\end{array}$} & \multirow[t]{2}{*}{$\begin{array}{c}\text { Kozuf } \\
2008\end{array}$} & \multirow[t]{2}{*}{$\begin{array}{l}\text { Nidze } \\
2008\end{array}$} & \multirow[t]{2}{*}{$\begin{array}{l}\text { Ilina Mtn. } \\
2008\end{array}$} \\
\hline & & & & & & & & & & & & \\
\hline Dodecanoic acid & 1643.2 & 0.03 & 0.01 & - & - & - & - & - & - & - & & - \\
\hline Tetradecanoic acid & 1860.6 & 0.04 & 0.02 & - & - & - & - & - & 0.02 & 0.05 & 0.10 & 0.08 \\
\hline Hexadecanoic acid & 2070.2 & 0.75 & 0.74 & 1.60 & 1.91 & 0.89 & 3.09 & 0.63 & 1.66 & 1.38 & 2.10 & 0.91 \\
\hline $\begin{array}{l}9,12 \text {-ocatadecadienoic } \\
\text { acid }\end{array}$ & 2258.0 & - & - & 0.42 & 1.03 & 0.10 & 1.84 & 0.20 & 0.32 & 1.52 & 1.49 & 0.93 \\
\hline $\begin{array}{l}9,12,15 \text {-octadecatrienoic } \\
\text { acid* }\end{array}$ & & 0.60 & 0.42 & 0.73 & 1.23 & 0.20 & 3.17 & 0.41 & 1.24 & - & 0.98 & 0.88 \\
\hline Octadecanoic acid * & & 0.16 & 0.14 & 0.55 & 0.45 & 0.04 & - & - & 0.27 & 0.41 & 0.75 & 0.63 \\
\hline Total fatty acids: & & 1.58 & 1.33 & 3.30 & 4.62 & 1.23 & 8.10 & 1.24 & 3.51 & 3.36 & 5.42 & 3.43 \\
\hline $\begin{array}{l}\text { ALCOHOLS } \\
\text { 2,4-di-tert-butylphenol }\end{array}$ & 1590.3 & - & - & - & - & 0.04 & - & 0.04 & 0.12 & 0.08 & 0.03 & 0.03 \\
\hline Tetradecanol & 1765.2 & - & 0.01 & - & - & - & 0.13 & - & $\operatorname{tr}$ & - & - & - \\
\hline Phytol (isomer) ${ }^{t^{*}}$ & 1939.1 & - & - & - & - & 0.09 & 0.26 & 0.05 & 0.25 & 0.05 & 0.03 & 0.03 \\
\hline 2-Hexadecen-1-ol & 1981.0 & - & 0.05 & - & - & 0.03 & 0.12 & - & 0.09 & 0.01 & 0.04 & - \\
\hline Oleyl alcohol & 2091.1 & 2.88 & 2.86 & 1.75 & 1.98 & 3.88 & 1.28 & 1.31 & 2.12 & 1.90 & 0.75 & 0.45 \\
\hline Octadecanol & 2198.8 & 0.23 & 0.21 & 0.08 & - & 0.15 & - & 0.04 & 0.69 & 0.12 & 0.12 & 0.07 \\
\hline Total alcohols: & & 3.11 & 3.13 & 2.06 & 1.98 & 3.99 & 1.79 & 1.44 & 3.29 & 2.17 & 0.97 & 0.58 \\
\hline $\begin{array}{l}\text { STEROLS } \\
\text { (-)-Cholesterol* }\end{array}$ & & - & - & - & - & 0.09 & 0.29 & - & 0.29 & 0.26 & 0.28 & - \\
\hline $\begin{array}{l}22,23- \\
\text { dihydrobrassicasterol* }\end{array}$ & & 0.80 & 0.78 & - & - & 0.27 & 0.90 & 0.26 & 0.47 & 0.47 & 0.65 & 0.25 \\
\hline Stigmasterol* & & 0.90 & 0.88 & 0.34 & 0.45 & 0.47 & 1.37 & 0.39 & 0.69 & 0.85 & 0.94 & 0.61 \\
\hline$\gamma$-Sitosterol* & & - & 1.97 & 1.49 & 1.91 & 1.55 & 3.86 & 0.82 & 2.75 & 1.84 & 3.30 & 2.05 \\
\hline Total sterols: & & 1.70 & 3.63 & 1.83 & 2.36 & 2.38 & 6.42 & 1.47 & 4.20 & 1.58 & 5.17 & 2.95 \\
\hline TRITERPENS & & & & & & & & & & & & \\
\hline Squalene* & & 0.17 & 0.15 & 0.48 & 0.54 & 0.40 & 0.66 & 0.07 & 1.01 & 0.52 & 0.66 & 0.37 \\
\hline$\beta$-Amyrine* & & 0.43 & 0.41 & 0.29 & 0.46 & 0.73 & 0.36 & 0.28 & 0.39 & 0.63 & 2.10 & 0.99 \\
\hline$\alpha$-Amyrine* & & 0.40 & 0.38 & 0.78 & - & 0.40 & 0.41 & 0.19 & 0.28 & 0.35 & 0.25 & 0.30 \\
\hline Triterpene alcohol*t & & 0.18 & 0.16 & - & - & $\operatorname{tr}$ & - & 0.01 & - & 0.19 & 0.37 & 0.37 \\
\hline Total triterpens: & & 1.18 & 1.10 & 1.55 & 1.00 & 1.54 & 1.53 & 0.55 & 1.68 & 1.69 & 3.38 & 2.03 \\
\hline OTHER COMPOUNDS & & & & & & & & & & & & \\
\hline $\begin{array}{l}\text { Hexahydrofarnesil } \\
\text { acetone }\end{array}$ & 1946.2 & 0.09 & 0.07 & - & - & 0.08 & 0.09 & 0.01 & - & 0.07 & 0.14 & 0.10 \\
\hline TOTAL & & & 86.90 & 88.67 & 89.40 & 83.98 & 89.90 & 60.14 & 87.98 & 90.96 & 91.25 & 59.95 \\
\hline
\end{tabular}

* - identification according NIST or Wiley (without AMDIS), ${ }^{\mathrm{t}}$ - tentative identification (AMDIS); ( - )- not found; ( / ) - not aveiable; KIE - estimated retention indices, cultivated plant 
Table 3. Chemical composition of hexane extracts of Sideritis raeseri from different location from Macedonia and Albania

\begin{tabular}{|c|c|c|c|c|c|c|c|c|}
\hline Components & KIE & \multicolumn{2}{|c|}{$\begin{array}{l}\text { Baba Mtn. } \\
\text { Macedonia } \\
20082009\end{array}$} & \multirow[t]{2}{*}{$\begin{array}{c}\text { Galicica } \\
\text { Macedonia } \\
2008\end{array}$} & \multicolumn{2}{|c|}{$\begin{array}{c}\text { Gramoz Mtn } \\
\text { Albania } \\
20082009\end{array}$} & \multirow[t]{2}{*}{$\begin{array}{c}\text { Tepelena } \\
\text { Albania } \\
2008\end{array}$} & \multirow[t]{2}{*}{$\begin{array}{c}\text { Logora Mtn. } \\
\text { Albania } \\
2008\end{array}$} \\
\hline MONO and SESQUITERPENS & & & & & & & & \\
\hline$\alpha$-Pinene & 951.1 & 0.10 & $\operatorname{tr}$ & 0.05 & 0.26 & 0.05 & 0.18 & $\operatorname{tr}$ \\
\hline Camphene & 960.7 & - & - & - & - & - & - & - \\
\hline$\beta$-Pinene & 980.8 & 1.20 & 0,08 & 0.11 & 0.58 & 0.90 & 0.36 & $\operatorname{tr}$ \\
\hline$\beta$-Myrcene & 992.6 & - & - & - & - & - & - & - \\
\hline D-Limonene $+\beta$-Phellandren & 1024.2 & $\operatorname{tr}$ & $\operatorname{tr}$ & $\operatorname{tr}$ & $\operatorname{tr}$ & $\operatorname{tr}$ & $\operatorname{tr}$ & $\operatorname{tr}$ \\
\hline trans-Pinocarveole & 1144.8 & 0.10 & 0,04 & $\operatorname{tr}$ & $\operatorname{tr}$ & $\operatorname{tr}$ & - & $\operatorname{tr}$ \\
\hline cis-Verbenol & 1152.6 & $\operatorname{tr}$ & $\operatorname{tr}$ & $\operatorname{tr}$ & $\operatorname{tr}$ & $\operatorname{tr}$ & - & $\operatorname{tr}$ \\
\hline Myrtenol & 1212.9 & 0.10 & & $\operatorname{tr}$ & 0.02 & 0.04 & - & $\operatorname{tr}$ \\
\hline (-)-Verbenone & 1230.5 & 0.08 & 0,02 & $\operatorname{tr}$ & $\operatorname{tr}$ & $\operatorname{tr}$ & $\operatorname{tr}$ & $\operatorname{tr}$ \\
\hline$\alpha$-Cubebene & 1403.6 & 0.05 & 0,02 & 0.05 & 0.10 & 0.12 & - & - \\
\hline$\alpha$-Copaene & 1437.4 & 0.20 & 0,24 & 0.12 & $\operatorname{tr}$ & 0.10 & 0.05 & 0.04 \\
\hline Muurola-4(14),15-diene (cis) & 1454.2 & - & $\operatorname{tr}$ & 0.08 & $\operatorname{tr}$ & $\operatorname{tr}$ & $\operatorname{tr}$ & - \\
\hline trans-Caryophyllene & 1488.7 & 0.20 & 0,34 & 0.11 & 0.79 & 0.56 & 0.52 & 0.31 \\
\hline Muurola-3,5-diene (trans) & 1524.7 & 0.01 & - & - & - & - & - & - \\
\hline$\alpha$-Hummulene & 1528.9 & 0.10 & 0,12 & 0.06 & 0.04 & 0.06 & $\operatorname{tr}$ & - \\
\hline Germacren D & 1560.7 & 0.02 & 0,06 & 0.06 & 0.06 & 0.02 & 0.02 & 0.04 \\
\hline Bicyclogermacrene & 1578.1 & - & - & 0.08 & - & - & 0.04 & - \\
\hline$\alpha$-Muurolene & 1580.3 & 0.01 & 0,01 & - & - & $\operatorname{tr}$ & - & - \\
\hline$\beta$-Bisabolene & 1588.8 & 0.04 & 0,06 & 0.04 & 0.10 & $\operatorname{tr}$ & - & - \\
\hline$\delta$-Cadinene & 1606.4 & 0.22 & 0,35 & 0.16 & 0.15 & 0.15 & 0.11 & 0.10 \\
\hline Cadina-1,4-diene (trans) & 1617.3 & 0.05 & 0,05 & 0.04 & - & - & - & 0.29 \\
\hline$\alpha$-Calacorene & 1630.2 & 0.02 & 0,02 & 0.03 & - & $\operatorname{tr}$ & - & - \\
\hline (-)-Spatulenol & 1670.2 & $\operatorname{tr}$ & 0,02 & 0.06 & 0.07 & 0.05 & 0.03 & $\operatorname{tr}$ \\
\hline Caryophyllene oxide & 1677.0 & 0.15 & 0,15 & 0.12 & 0.18 & 0.12 & 0.08 & 0.11 \\
\hline Viridiflorol & 1686.1 & 0.09 & 0,24 & 0.08 & 0.06 & 0.10 & - & $\operatorname{tr}$ \\
\hline$\beta$-Gurjunenepoxide & 1690.0 & $\operatorname{tr}$ & 0,01 & - & $\operatorname{tr}$ & $\operatorname{tr}$ & - & $\operatorname{tr}$ \\
\hline $\begin{array}{l}\alpha \text {-Cadinol }+ \\
\tau \text {-Muurolol }\end{array}$ & $\begin{array}{l}1739.1 \\
1739.5\end{array}$ & 0.50 & 1,27 & 0.24 & 0.24 & 0.58 & 0.04 & $\operatorname{tr}$ \\
\hline Valeranone & 1776.5 & 0.05 & 0,05 & 0.11 & - & - & 0.06 & $\operatorname{tr}$ \\
\hline$\alpha$-Bisabolole & 1780.6 & 0.06 & 0,05 & 0.03 & - & - & 0.02 & $\operatorname{tr}$ \\
\hline Total mono and sesquiterpens: & & 3.36 & 3.32 & 1.68 & 2.72 & 3.94 & 1.56 & 1.02 \\
\hline $\begin{array}{l}\text { DITERPENS } \\
(+) \text {-Beyerene }\end{array}$ & 2057.7 & 0.08 & 0,03 & - & 0.05 & 0.03 & 0.05 & 0.04 \\
\hline Pimara-8(14),15-diene & 2072.4 & - & - & - & - & - & - & - \\
\hline Kaur-15-en & 2125.2 & 0.10 & $\operatorname{tr}$ & 0.03 & 0.09 & 0.07 & 0.12 & 0.09 \\
\hline Manoyl oxide & 2145.9 & 0.05 & 0.03 & - & 0.02 & 0.01 & 0.01 & - \\
\hline 3a-Hydroxy manool (M=288) & 2327.5 & 0.20 & 0,21 & 0.10 & 0.33 & 0.37 & 0.47 & 0.23 \\
\hline
\end{tabular}




\begin{tabular}{|c|c|c|c|c|c|c|c|c|}
\hline \multirow[b]{2}{*}{$\begin{array}{l}\text { 7-ethenyl-1- } \\
, 2,3,4,4 \mathrm{a}, 4 \mathrm{~b}, 5,6,7,9,10,10 \mathrm{a}-\text { dodeca- } \\
\text { hydro-1,1,4a,7-tetramethyl-2-phenan- } \\
\text { threnol }(\mathrm{M}=306)\end{array}$} & \multirow{2}{*}{$\begin{array}{c}\text { KIE } \\
2335.8\end{array}$} & \multicolumn{2}{|c|}{$\begin{array}{l}\text { Baba Mtn. } \\
\text { Macedonia } \\
20082009\end{array}$} & \multirow{2}{*}{$\begin{array}{c}\text { Galicica } \\
\text { Macedonia } \\
2008 \\
\\
0.07\end{array}$} & \multicolumn{2}{|c|}{$\begin{array}{c}\text { Gramoz Mtn } \\
\text { Albania } \\
2008 \quad 2009\end{array}$} & \multirow{2}{*}{$\begin{array}{c}\text { Tepelena } \\
\text { Albania } \\
2008\end{array}$} & \multirow{2}{*}{$\begin{array}{c}\text { Logora Mtn. } \\
\text { Albania } \\
2008 \\
\\
0.33\end{array}$} \\
\hline & & 0.24 & 0,22 & & 0.21 & 0.24 & & \\
\hline Diterpene $(\mathrm{M}=306)$ & 2374.2 & 0.22 & 0,15 & 0.11 & 0.14 & 0.20 & - & 0.27 \\
\hline Diterpene (M=306) & 2387.9 & - & - & - & - & - & - & - \\
\hline Diterpene $(\mathrm{M}=306)$ & 2459.0 & - & 0,20 & 0.18 & 0.33 & 0.20 & 0.68 & 0.50 \\
\hline Diterpene $(\mathrm{M}=286)$ & 2487.7 & 10.36 & 8.99 & 5.40 & 21.07 & 15.87 & 18.22 & 13.16 \\
\hline Diterpene $(\mathrm{M}=286)$ & & 17.53 & 11.49 & 3.41 & 18.36 & 18.02 & 25.64 & 23.96 \\
\hline Diterpene $(\mathrm{M}=346)$ & & 1.20 & 0,20 & 0.08 & 0.65 & 0.45 & 0.25 & 0.21 \\
\hline Diterpen $(\mathrm{M}=286)$ & & 1.35 & 0,82 & 0.24 & 1.45 & 1.31 & - & 2.13 \\
\hline Total diterpens: & & 31.31 & 22.35 & 9.62 & 42.73 & 36.65 & 45.81 & 14.92 \\
\hline $\begin{array}{l}\text { ESTERS } \\
\text { Benzyl benzoate }\end{array}$ & 1924.3 & $\operatorname{tr}$ & $\operatorname{tr}$ & 0.02 & - & 0.05 & 0.02 & 0.03 \\
\hline Isopropyl tetradecanoate & 1978.5 & 0.05 & $\operatorname{tr}$ & 0.03 & $\operatorname{tr}$ & 0.35 & 0.03 & 0.03 \\
\hline Di-isobutyl phthalate* & 2029.2 & 0.06 & 0,04 & 0.41 & 0.05 & 0.06 & 0.06 & 0.11 \\
\hline Methyl hexadecanoate & 2103.3 & - & 0,08 & 0.10 & 0.02 & 0.08 & 0.21 & 0.19 \\
\hline Hexadecanoic acid ethylester & 2135.6 & 0.04 & 0,10 & 0.06 & - & 0.12 & 0.20 & - \\
\hline Isopropyl hexadecanoate & 2243.4 & - & - & - & - & - & - & 0.54 \\
\hline Methyl octadecanoate & 1924.3 & 1.35 & 2,54 & 0.07 & 0.62 & 2.86 & 0.06 & - \\
\hline 9,12-Octadienoic acid ethylester & 1978.5 & 0.18 & 0,14 & 0.15 & - & 0.12 & 0.12 & 0.11 \\
\hline Dodecenol acetat $*$ & & & 0,15 & 0.03 & 1.10 & 0.79 & 0.27 & 0.28 \\
\hline Myristyl tetradecanoate * & & 0.12 & 0,17 & 0.18 & 0.04 & 0.26 & 0.09 & 0.23 \\
\hline Total esters: & & 1.81 & 3.24 & 1.05 & 0.84 & 4.69 & 1.06 & 1.52 \\
\hline $\begin{array}{l}\text { HYDROCARBONS } \\
\text { Heptadecane }\end{array}$ & 1790.5 & 0.02 & 0,03 & 0.04 & $\operatorname{tr}$ & 0.04 & - & $\operatorname{tr}$ \\
\hline Octadecane & 1896.4 & 0.02 & 0,01 & 0.02 & $\operatorname{tr}$ & 0.03 & - & $\operatorname{tr}$ \\
\hline Nonadecane & 2002.0 & - & - & - & - & - & - & - \\
\hline Eicosane & 2108.2 & 0.09 & 0,08 & 0.06 & 0.06 & 0.06 & 0.09 & 0.04 \\
\hline Heneicosane & 2213.4 & - & 0,04 & 0.06 & - & 0.04 & 0.07 & 0.04 \\
\hline Docosane & 2318.5 & 0.26 & 0,21 & 0.10 & $\operatorname{tr}$ & 0.02 & 0.15 & 0.15 \\
\hline Tricosane & 2423.2 & 0.41 & 0,21 & 0.17 & 0.40 & 0.34 & 0.43 & 0.36 \\
\hline Tetracosane & 2528.7 & 0.21 & 0,10 & 0.11 & 0.16 & 0.15 & 0.35 & 0.11 \\
\hline Pentacosane & 2631.0 & 0.75 & 0,47 & 0.45 & 0.79 & 0.54 & 0.97 & 0.81 \\
\hline Hexacosane & 2691.5 & 0.08 & 3.52 & 0.05 & 0.13 & 0.11 & 0.17 & 0.15 \\
\hline Heptacosane & 2784.4 & 3.97 & 0.74 & 4.29 & 3.81 & 2.67 & 2.98 & 3.06 \\
\hline Octacosen* & 2810.3 & 1.15 & & 0.63 & 1.16 & 0.78 & 1.66 & 0.97 \\
\hline Octacosane & 2822.2 & 0.53 & 0,66 & 0.74 & 1.08 & 0.83 & 0.92 & 0.53 \\
\hline Nonacosane & 3024.6 & 11.35 & 15.55 & 19.68 & 8.87 & 8.20 & 7.79 & 7.46 \\
\hline Triacontane & 3025.1 & 0.56 & 0,93 & 1.24 & 0.48 & 0.87 & 0.65 & 0.66 \\
\hline Hentriacontane & 3132.3 & 14.50 & 25.40 & 30.31 & 8.09 & 13.25 & 10.39 & 9.14 \\
\hline Dotriacontane* & & 0.72 & 0.97 & 1.35 & - & 0.78 & 0.34 & 0.51 \\
\hline
\end{tabular}




\begin{tabular}{|c|c|c|c|c|c|c|c|c|}
\hline Components & KIE & $\begin{array}{l}\text { Baba } \\
\text { Mace } \\
2008\end{array}$ & $\begin{array}{l}\text { Mtn. } \\
\text { donia } \\
2009\end{array}$ & $\begin{array}{c}\text { Galicica } \\
\text { Macedonia } \\
2008\end{array}$ & $\begin{array}{r}\text { Gram } \\
\text { All } \\
2008\end{array}$ & $\begin{array}{l}\text { z Mtn } \\
\text { ania } \\
2009\end{array}$ & $\begin{array}{c}\text { Tepelena } \\
\text { Albania } \\
2008\end{array}$ & $\begin{array}{c}\text { Logora Mtn. } \\
\text { Albania } \\
2008\end{array}$ \\
\hline Tritriacontane * & & 4.05 & 8.02 & 8.94 & 4.27 & 4.05 & 2.68 & 2.23 \\
\hline Total hydrocarbons: & & 38.67 & 59.94 & 68.12 & 29.33 & 32.76 & 29.64 & 26.24 \\
\hline $\begin{array}{l}\text { FATTY ACIDS } \\
\text { Dodecanoic acid }\end{array}$ & 1643.2 & $\operatorname{tr}$ & $\operatorname{tr}$ & 0.06 & - & - & - & 0.03 \\
\hline Tetradecanoic acid & 1860.6 & 0.06 & 0,02 & 0.10 & 0.04 & 0.05 & - & 0.16 \\
\hline Hexadecanoic acid & 2070.2 & 0.92 & 1,87 & 2.23 & 0.03 & 2.72 & 0.55 & 3.68 \\
\hline 9,12-ocatadecadienoic acid & 2258.0 & 0.40 & 0,54 & 1.80 & 0.55 & 0.68 & 0.06 & 0.83 \\
\hline $9,12,15$-octadecatrienoic acid* & - & - & - & - & - & - & - & 0.30 \\
\hline Octadecanoic acid* & - & - & - & 0.73 & - & - & - & 0.30 \\
\hline Total fatty acids: & & 1.39 & 2.44 & 4.92 & 0.62 & 3.45 & 0.61 & 5.30 \\
\hline $\begin{array}{l}\text { ALCOHOLS } \\
\text { 2-Nonen-1-ol }\end{array}$ & 1072.3 & $\operatorname{tr}$ & 0,02 & $\operatorname{tr}$ & - & - & - & - \\
\hline 2,4-di-tert-butylphenol & 1590.3 & 0.06 & $\operatorname{tr}$ & 0.12 & - & 0.07 & 0.09 & 0.11 \\
\hline Tetradecanol & 1765.2 & 0.12 & 0,17 & 0.24 & 0.05 & 0.17 & 0.07 & 0.25 \\
\hline Phytol (isomer) ${ }^{t}$ & 1939.1 & 0.05 & 0,20 & 0.07 & 0.16 & 0.23 & 0.08 & 0.04 \\
\hline 2-Hexadecen-1-ol & 1981.0 & 0.04 & 0,07 & 0.03 & - & - & - & - \\
\hline Oleyl alcohol * & 2091.1 & 1.82 & 1,04 & 0.28 & 1.51 & 1.23 & 2.07 & 2.80 \\
\hline Octadecanol & 2198.8 & 1.12 & 0,06 & - & 0.07 & 0.06 & 0.10 & \\
\hline Total alcohols & & 3.22 & 1.50 & 0.75 & 1.79 & 1.76 & 2.41 & 3.20 \\
\hline $\begin{array}{l}\text { STEROLS } \\
(-) \text {-Cholesterol* }\end{array}$ & & 0.16 & 0,24 & - & 0.13 & 0.23 & 0.28 & 0.36 \\
\hline 22,23-dihydrobrassicasterol * & & 0.52 & 0,43 & 0.26 & 0.36 & 0.42 & 0.28 & 0.20 \\
\hline Stigmasterol* & & 0.75 & 0,77 & 0.61 & 0.79 & 0.55 & 0.46 & 0.49 \\
\hline$\gamma$-Sitosterol* & & 2.27 & 2,36 & 1.88 & 2.07 & 1.91 & 1.69 & 1.35 \\
\hline Total sterols & & 3.70 & 3.80 & 2.75 & 3.35 & 3.11 & 2.71 & 2.40 \\
\hline $\begin{array}{l}\text { TRITERPENS } \\
\text { Squalene * }\end{array}$ & & 0.36 & 0,48 & 0.52 & 0.45 & 0.52 & 0.31 & 1.41 \\
\hline$\beta$-Amyrine* & & 0.59 & 0,36 & 0.82 & 0.56 & 0.31 & 0.56 & 0.44 \\
\hline$\alpha$-Amyrine* & & 0.39 & 0,28 & 0.23 & 0.57 & 0.41 & 0.53 & 0.42 \\
\hline Triterpene alcohol ${ }^{\mathrm{t}} *$ & & 0.33 & 0,22 & 0.27 & 0.24 & 0.13 & 0.17 & 0.11 \\
\hline Total triterpens & & 1.67 & 2.01 & 1.84 & 1.82 & 1.37 & 1.57 & 2.38 \\
\hline $\begin{array}{l}\text { OTHER COMPOUNDS } \\
\text { Hexahydrofarnesil acetone }\end{array}$ & 1946.6 & - & 0,08 & 0.17 & 0.12 & 0.09 & 0.10 & 0.08 \\
\hline TOTAL & & 85.15 & 98.68 & 90.90 & 83.29 & 80.94 & 85.47 & 83.06 \\
\hline
\end{tabular}

\footnotetext{
* - identification according NIST or Wiley (without AMDIS), ${ }^{\mathrm{t}}$ - tentative identification (AMDIS); ( - )- not found; KIE - estimated retention indices
} 


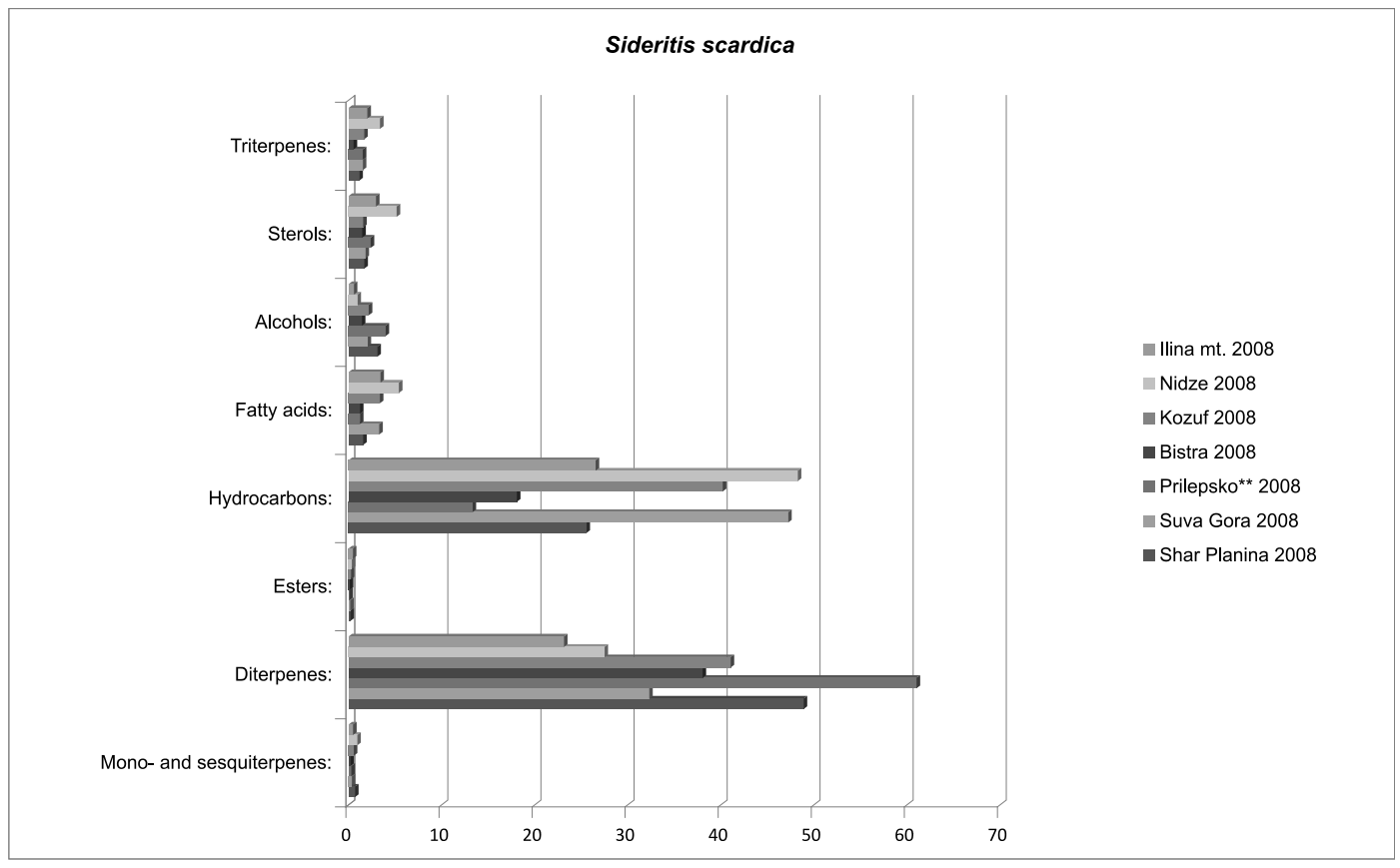

Fig. 1. The content of different types of components in the $n$-hexane extracts of Sideritis scardica

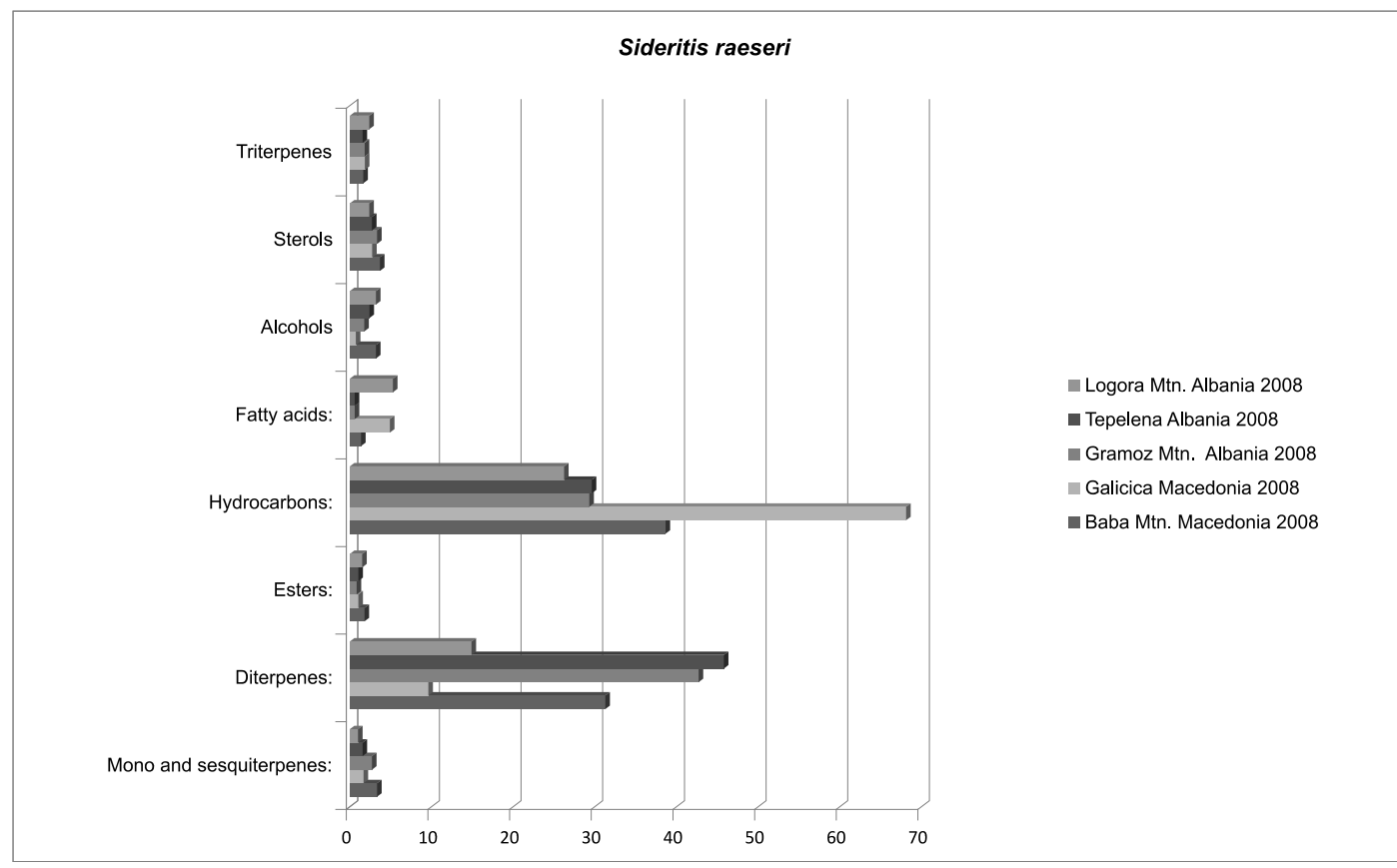

Fig. 2. The content of different types of components in the $n$-hexane extracts of Sideritis raeseri

type of diterpenes (Gomez-Serranillos et al., 1997, 1998; Topku et al., 2001, 2002). Seasonal variation in the content of some diterpenes were registered and the most variable was the most dominant diterpenes, mainly in the $n$-hexane extracts of $S$. scardica (Table 2 and 3).

In $n$-hexane extracts of $S$. scardica and $S$. scardica $S$. syriaca hybride, Kostadinova et al. (2008) found predom- inant presence of diterpene fractions in both species, in amounts from $13.8-54.1 \%$. Ten diterpene components were registered and only three were fully identified (manoyl oxide, 7-ethenyl-1,2,3,4,4a,4b,5,6,7,9,10,10a-dodecahydro1,1,4a,7-tetramethyl-2-phenanthrenol and pimara-8,15dine-3-ol. The other diterpene components had following molar mass: 288, 286, 290, 304 and 346. The most abun- 
dant was $\mathrm{M}=346$ diterpene. Comparing these data with our results, some similarities could be found. We also registered diterpene $\mathrm{M}=346$, but this components was present in a very small amounts in comparison to other components and especially to components with $\mathrm{M}=286$. As there were no other literature data considering diterpene components in $S$. scardica and $S$. raeseri, we made some comparations with other Sideritis species. Thus, Topcu et al. (2001) have defined ten diterpenees in Sideritis argyrea: candol, 7-epicandicanol, ent-7 $\alpha$-acetoxy-18-hydroxykaur-16-ene, foliol, linearol, sidol, 7-epocandicandiol 18-monoacetate, siderol and 11,12-sideridiol, all of them with kaurane skeleton and only one labdane diterpene named ent- $6 \alpha, 8 \alpha-$ dihydroxylabda-13(16)14-diene. Later, the same research group published that, besides above mentioned components, Sideritis sipilea and S. dichotoma contain also different kaurane isomers, but also some beyerne components (Topku et al., 2002). In Iberian's Sideritis species, GomezSerranilos et al. (2004) determined the content of ten diterpenes: serradiol, linearol, conchtriol, foliol, isofoliol, andalusol, lagascatriol, tobarrol, sidol and siderol, seven of them kauranes.

In general, diterpenes represented very interesting group of components because of their chemistry and their distribution in plants, the possibilities for their use as markers in order to find or approve some taxonomy solutions, but much more because of their possible biological and pharmacological activity and further use in healing illnesses or other use. For these reasons, diterpenees of Siderits scardica and $S$. raeseri should be further more investigated, for full identification and determination and assessment of possible biological activity.

\section{Conclussion}

The ultrasonic-assisted extraction process with $n$ hexane on dried over-ground parts of two species of Sideritis collected on different locations in western part of Macedonia and south-eastern part of Albania, yielded 0.73$3.33 \%$ and $9.11-10.44 \%$ of extracts for S. scardica Grieseb. and $S$. raeseri Boiss. \& Heldr., respectively. Over one hundred constituents of the extracts were identified using gas-chromatography (FID) and gas-chromatography/mass spectrometry methods. The components belonged to several classes of components such as diterpenes and hydrocarbons, dominantly presented in each of the extracts, followed by fatty acids, aliphatic and aromatic alcohols, sterols, triterpene alcohols and different monoterpenes and sesquiterpenes, found in much smaller amounts or traces. The most abundant constituents of the extracts of both species of Sideritis were two diterpenee components, both with $\mathrm{M}=286$, which were not fully identified. Large percentages of nonacosane (1.71-12.22\% and 7.46-19.68\% for S. scardica and S. raeseri, respectively) and hentriacontane (4.48-20.79\% and 8.09-30.31\% for S. scardica and S. raeseri, respectively) were also found in the extracts of both species. Season- al variation in the content of some diterpenes and hydrocarbones was found for the both species of Sideritis.

\section{References}

Aboutabl, E.A., Nassar, M.I., Elsakhawy, F.M., Maklad, Y.A., Osman, A.F., El-Khrisy, E.A.M., 2002. Phytochemical and pharmacological studies on Sideritis taurica Stephan ex Wild, J. Ethnopharmac. 82, 177-184.

Alcaraz, M.J., Jimenez, M.J., Valverde, S., Sanz, J., Rabanal, R.M., Villar, A., 1989. Anti-inflammatory compounds from Sideritis javalambrensis n-hexane extract, J. Nat. Prod. 52 (5), 1088-1091

Alipieva, K., Petreska, J., Gil-izquierdo, A., Stefova, M., Evstatieva, L., Bankova, V., 2010. Influence of the extraction method on the yeald of flavonoids and phenoluics from Sideritis spp. (Pirin Mountain tea), Nat. Prod. Commun. 5, 51- 54.

Alipieva, K.I., Kostadinova, E.P., Evstatieva, L.N., Stefova, M., Bankova, S.V., 2009. An iridoid and a flavonloid from Sideritis lanata L., Fitoterapia 80 (1), 51- 53.

Armata, M., Gabrieli, C., Termentzi, A., Zervou, M., Kokkalou, E., 2008. Constituents of Sideritis syriaca ssp. syriaca (Lamiaceae) and their antioxidant activity, Food Chemistry $111,179-186$

Erkan, N., Cetin, H., Ayranci, E., 2011. Antioxidant activities of Sideritis congesta Davis et Huber-Morath and Sideritis arguta Bois et Heldr: Identification of free flavonoids and cinnamic derivatives, Food Research International 44, 297-303.

Gabrieli, C.N., Kefalas, P.G., Kokkalou, E.L., 2005. Antioxidant activity of flavonoids from Sideritis raeseri, J. Ethnopharmac. 96, 423-428.

Gomez-Serranillos, M.P., Carretero, E., Slowing, K., Palomino, O.M., Villarrubia, A.I., Villar, A., 1998. HPLC quiantitative analysis of diterpeneoids in Sideritis (Labiatae) species, Phytoth. Res. 12, 101-103.

Gomez-Serranillos. M.P., El-Nager. T., Villar. A.M., Carretero. M.E., 2004. Analysis of retention behavior in highperformance liquid chromatography of terpenic plant constituents (Sideritis spp.) with pharmacological interest, J. Chromatogr. B, 812, 379-383.

Gomez-Serranillos M.P., Palomino O.M., Villarrubia A.I., Cases M.A., Carretero E., Villar A., 1997. Analysis of diterpeneoids from Sideritis species by reversed-phase high-performance liquid chromatography, J. Chromatogr. A, 778, 421-425.

Janeska, B., Stefova, M. Alipieva, K., 2007. Assay of flavonoid aglycones from the species of genus Sideritis (Lamiaceae) from Macedonia with HPLC-UV DAD, Acta Pharm. 57, 371-377.

Koleva, I.I., Linssen, J.P.H., van Beek, T.A., Evstatieva, L.N., Kortenska, V., Hadjieva, N., 2003. Antioxidant activity screening of extracts from Sideritis species (Labiatae) grown in Bulgaria, J. Sci. Food. Agric., 83, 809-819.

Kostadinova, E., Alipieva, K., Stefova, M., Antonova, D., Evstatieva, L., Stefkov, G., Tsvetkova, I., Naydenski, H., Bankova, V., 2008. Influence of cultivation on the chemical composition and antimicrobial activity of Sideritis spp., Pharmacog. Magazine 4, 102-106.

Kostadinova, E., Nikolova, D., Alipieva, K., Stefova, M., Stefkov, G., Evstatieva, L., Matevski, V., Bankova, V., 2007. Chemical constituents of essential oils of Sideritis scardica Griseb. and Sideritis raeseri Boiss. \& Heldr. From Bulgaria 
and Macedonia, Nat. Prod. Res., 21 (9), 819-823.

Lysyansky, V.M., Grebenyuk, S.M., 1987. Extraction in food industry, Agropromizdat, Moskow, pp. 188.

Menghini, L., Massarelli, P., Bruni, G., Menghini, A., 2005. Preliminary evaluation on anti-inflamatory and analgesic effects of Sideritis syriaca L. herba extracts, J. Med. Food 8 (2), 227-231.

Ozkan, G., Sagdic, O, Ozcan, M., Ozcelik, H., Unver, A., 2005. Antioxidant and antibacterial activities of Turkish endemic Sideritis extracts, Grasas y Aceites 56, 16-20.

Palommino, O.M., Gomez-Serranillos, P., Carretero, E., Villar, A., 1996. High-performance liquid chromatography of flavonoids from Sideritis species, J. Chromatog. A, 731, 103-108.

Petreska, J., Stefkov, G., Kulevanova, S., Alipieva, K., Bankova, V., Stefova, M., 2011. Phenolic compounds of Mountain tea from Balkans: $\mathrm{LC} / \mathrm{DAD} / \mathrm{ESI} / \mathrm{MS}^{\mathrm{n}}$ profile and contents, Nat. Prod. Comm. 6, 1-10.

Petreska, J., Stefova, M., Ferreres, F., Moreno, D.A., TomasBarberan, F.A., Stefkov, G., Kulevanova, S., Gil-Izquierdo, 2011. Potential bioactive phenolics of Macedonian Sideritis species used for medicinal "Mountain tea", Food Chemistry 125, 13-20.

Pljevljakusic, D., Savikin, K., Jankovic, T., Zdunic, G., Ristic, M., Godjevac, D., Konic-Ristic, A., 2011. Chemical properties of the cultivated Sideritis raeseri Boiss. \& Heldr. subsp. raeseri, Food Chemistry 124, 226-233.

Rodriguez-Garcia, I., Munoz-Dorado, M., Gomez-Mersado, F., Garcia-Maroto, F., Guill-Guerrero, Jl., 2004. Essential oil composition of Sideritis pusilla (Lange) Pau ssp., J. Essent. Oil. Res. 16, 535-538.

Semagina, N.V., Sulman, M.G., Sulman, E.M., Ankudinova T.V., 2000. Study of ultrasound-stimulated extraction of biologically active substances from row plant materials, Pharma. Chem. J. 34 (2), 69-72.

Sulman, M.G., Pirog, E.M., Ankudinova, T.V., Sulman, E.M., Semagina, N.V., 1997. The extraction process from the vegetable row materiasl in the ultrasonic field, $1^{\text {st }}$ European Congress on Chemical Engineering: Florence, Italy, vol. 4, p. 3017-3018.

Topku, G., Goren, A.C., Kilic, T., Kemal, Y., Tumen, G., 2001. Diterpenees from Sideritis argyrea, Fitoterapia 72, 1-4.

Topku G., Goren, A.C., Kilic, T., Kemal, Y., Tumen, G., 2002. Diterpenees from Sideritis sipylea and S. dichotoma, Turk. J. Chem. 26, 189-194.

Tsaknis, J., Lalas, S., 2005. Extraction and identification of natural antioxidants from Sideritis euboea (mountain tea), J. Agric. Food. Chem. 53 (16), 6375- 6381.

\title{
Хемиски состав на $\boldsymbol{n}$-хексански екстракти добиени со
} ултразвучна ектракција од Sideritis scardica Griseb. и Sideritis raeseri Boiss. \& Heldr. (Lamiaceae) од Македонија и Албанија

\author{
Бујар К'азими, Марија Карапанџова*, Ѓше Стефков, Светлана Кулеванова
}

\author{
Институт за Фармакогнозија, Фармацевтски Факултет, Универзитет Св. Кирил и Методиј, Скопје, Република \\ Македонија
}

Клучни зборови: Sideritis scardica, Sideritis raeseri, n- хексански екстракти, ултразвучна екстракција, состав, GC-MS анализа.

Хемиски состав на $n$-хексански екстракти добиени од суви надземни делови од два вида Sideritis, S. scardica Griseb. и S. raeseri Boiss. \& Heldr. (Lamiaceae) е испитуван со помош на гасна хроматографија (GC/FID) и гасна хроматографија/масена спектрометрија $(\mathrm{GC} / \mathrm{MS})$. Собирањето на растенијата е извршено на различни локалитети во западниот дел на Македонија и во јужниот дел на Албанија, вкупно дванаесет различни примероци на растителен материјал. Ултразвучната екстракција е користена за подготовка на $n$-хексански екстракти, а добиениот принос се движи од 0,73-3,33\% и 9,11-10,44\% на екстракти на S. scardica, односно S. raeseri. Во екстрактите се идентификувани повеќе од сто компоненти, кои што припаѓаат на неколку класи соединенија како што се дитерпени и јаглеводороди, главно присутни во секој екстракт, проследени со масни киселини, алифатични и ароматични алкохоли, стероли, тритерпенски алкохоли и разни монотерпени и сесквитерпени, што се најдени во многу помали количества или само во траги. Најзастапени компоненти на екстрактите од двата видови Sideritis се две дитерпенски компоненти, двете со М $=286$, кои што не се целосно идентификувани. Голем процент од нонакозан (1,71-12,22\% и 7,46-19,68\% за $S$. scardica, односно $S$. raeseri) и хентриаконтан (4,48 - 20,79\% и 8,09-30,31\% за S.scardica, односно S.raeseri) се најдени во екстрактите од двата вида. 


\title{
Influence of different formulations and granulation techniques on dissolution of folic acid in film coated tablets
}

\author{
Ljiljana Krsteska*, Dejan Kostovski, Ksenija Brzilova, Suzan M.Sejfulah, Sonja \\ Ugarkovic
}

\author{
Research and Development, ALKALOID AD, Aleksandar Makedonski 12, \\ 1000 Skopje, Republic of Macedonia
}

Received: May 2011; Accepted: July 2011

\begin{abstract}
The vitamin folic acid has received considerable attention because of it's role in decreasing risk of neural tube birth defects, and it's potential role in reducing risks of cardiovascular and psychiatric diseases. We evaluated compositions of 5 different formulations in terms of meeting the USP standard for dissolution and disintegration.However all the examined formulations had met the disintegration test but only 3 formulations had met the dissolution requirements to release $75 \%$ of the active ingredient in 45 minutes. The maximum value of dissolution of $97.52 \%$ in S5 composition was achieved by combination of certain excipients (combination of hydrophilic and hydrophobic filler and suitable wetting agent) and wet high shear mixing granulation technique, resulting with optimize release of the active substance.
\end{abstract}

Key words: solubility, dissolution, tablets, vitamins, folic acid.

\section{Introduction}

Folic acid is a B complex vitamin, used for prevention and treatment of vitamin B deficiency, and it can be isolated from green leafy vegetables, liver, yeast and fruits. Synthetic folic acid is also commercially available. According to the European Pharmacopoeia, the substance is characterized as yellowish or orange crystalline powder, practically insoluble in water and in most organic solvents, but it dissolves in dilute acids and in alkaline solutions. Folic acid obtained from preparations is more bioavailable than dietary folate, since up to half of dietary folate is lost in the cooking process and requires hydrolysis for absorption (Suitor and Bailey, 2000). The failure of folic acid supplements to meet several pharmacopoeial requirements for disintegration has been reported earlier (Stout et al., 1996). Monograph for folic acid tablets in the current edition of US Pharmacopoeia (The United States Pharmacopeia Con-

\footnotetext{
*1krstevska@alkaloid.com.mk
}

vention, 2010) declare that not less that $75 \%$ of the labeled amount should be released and dissolved in the time period of 45 minutes.

Because of the historical experience of certain folic acid tablet failures and current demands of the US Pharmacopoeia, as well as because retaining the policy of quality and safety of the products, the development of future vitamin formulation should be made in a systematic way.

During the development of a medical product a dissolution test is used as a tool to identify formulation factors that influence on the dissolution rates of the active substance and may have a crucial affect on the bioavailability of the drug. As soon as composition and the manufacturing process is defined dissolution test is used in quality control of scale up and of production batches to ensure both batch-batch-consistency in certain instances a dissolution test can be used to waive a bioequivalence study (EMA, 2006). The aim of this study was to developed Folic acid film-coated tablets formulation that will release not less than $90 \%$ of the labeled amount of folic acid into the dissolution media. For this purpose, several formulations with 
different excipients were evaluated, as well as two technological approaches of producing the tablets.

\section{Materials and Methods}

For the purpose of determining the optimal formulation, several combinations of fillers, disintegrants and binders were evaluated, as well as two preparing techniques wet granulation by high-shear mixer (HS) and dry mixing (DM) for direct compression were used. The complete overview can be seen in Table 2. Folic acid was obtained from manufacturer BASF GmbH Germany, Lactose monohydrate from Meggle, Wasserburg GmbH\&Co, Microcrystalline cellulose from FMC Bio Polymer Wallingstown, Little Island Co Work, Ireland, Dicalcium phosphate from Budenheim, Germany, Silicon dioxide from Evonik Deggusa.

The particle size distribution of the active ingredient was measured on Morphologi - G3S, Malvern Instruments. The United States Pharmacopeial Convention, general chapter $<776>$ optical microscopy. The dissolution test was performed according to dissolution method described in The United States Pharmacopeial Convention, general chapter $<711>$ dissolution, using Apparatus II - paddle, paddle speed $50 \mathrm{rpm}$. Determination was made with HPLC system equipped with UV/VIS detector. Dissolution specification was NLT $75 \%(\mathrm{Q})$ of released and dissolved Folic acid for time period of $45 \mathrm{~min}$.

Desintegration of film-coated tablets was performed on Erweka desintegration tester type ZT 302. The disintegration test was performed according to disintegration method described in The United States Pharmacopeial Convention, general chapter $<701>$ disintegration. Bulk and tapped density, compressibility index of granulates and mixtures for direct compression were tested on Tapped volumeter SVM100. The United States Pharmacopeial Convention, general chapter $<616>$ bulk density and tapped density of powders. Loss on drying (LOD) of granulates and mixtures for direct compression were tested on Mettler Toledo HG 63. The disintegration test was performed according to disintegration method described in The United States Pharmacopeial Convention, general chapter $<731>$ loss on drying. Different formulations of tablet cores were produced on a rotary tablet press, with punch diameter of $7 \mathrm{~mm}$ and average mass of $110 \mathrm{mg}$. Tablet cores were coated in a conventional coating pan with PVA (Polyvinyl Acetate) based film coating until total mass of $115 \mathrm{mg}$ was gained.

\section{Results and discussion}

\section{API characterization}

The particle size distribution of API plays important role in the dissolution rate of tablets. When API is insoluble, micronized active ingredient is a rational approach in the formulation (Amiji and Sandman, 2003). The particle size distribution of folic acid has $\mathrm{D}[0.9]$ below $50 \mu \mathrm{m}$, which complies micronized compounds.

The particle size distribution of Folic acid is presented in Table 1 and Fig. 1.

Table 1. Particle size analysis of folic acid from manufacturer BASF GmbH

FOLIC ACID / manufacturer BASF GmbH /

Batch. No.HMNB913

\begin{tabular}{ccc} 
Sieve size & Results \\
\hline $10 \mu \mathrm{m}<$ & $2.0 \%$ \\
$20 \mu \mathrm{m}<$ & $34.7 \%$ \\
$30 \mu \mathrm{m}<$ & $98.0 \%$ \\
$\mathrm{D}[0.9]$ & $\mathrm{D}[0.2]$ & $\mathrm{D}[0.1]$ \\
98.0 & 34.7 & 2.0 \\
\hline
\end{tabular}

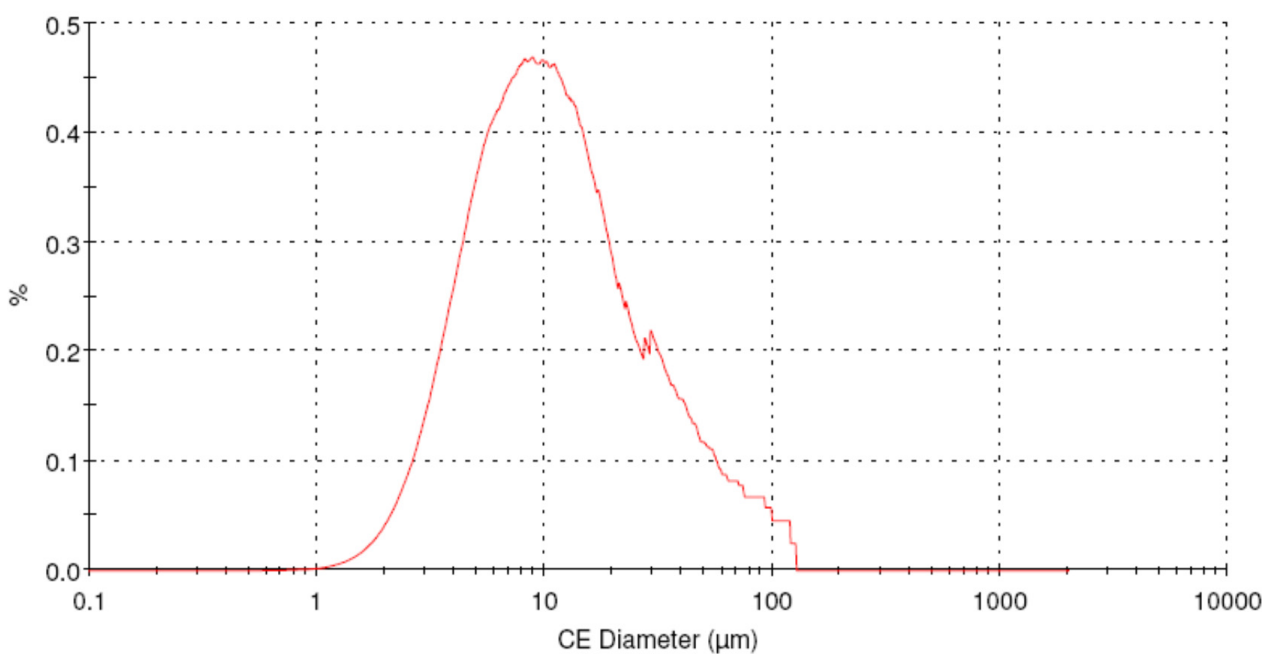

Fig. 1. Graphical presentation of the particle size distribution of the analyzed sample from manufacturer BASF GMBH 
Determination of physical parameters of granulates of different formulations (S1-S5)

All process control parameters bulk and tapped density, compressibility index, flow ability and LOD for all examined formulations were within prescribed range of the United States Pharmacopeial Convention., 2010 (Table 2) confirming the physical preferences of the granulates. Results from process control parameters carried out on the fine blends of examined formulations are displayed in Table 2.

\section{Disintegration}

When the tablet disintegrates it is broken down into small particles, which offers a greater surface area to the dissolving media resulting in improvement of the dissolution rate of the drug. However, disintegration test offer no assurance that formulation will release the drug, even in the form of small particles, since a drug must normally be in solution before absorption can take place. Results from process control parameter of disintegration time carried out on the film coated tablets of examined formulations has been tested on each five examined composition and are displayed in Table 3.

All the tested products met European Pharmacopoeia requirements for disintegration time (Table 3 ). The longer disintegration time of formulation $\mathrm{S} 2$ can be explained with the addition of dicalcium phosphate, water insoluble filler. The rest of the formulations disintegrated in not more that $3 \mathrm{~min}$.

Table 2. Process control of examined compositions

\begin{tabular}{cccccc}
\hline \hline Parameters & $\begin{array}{c}\text { Bulk density } \\
(\mathrm{g} / \mathrm{ml})\end{array}$ & $\begin{array}{c}\text { Tapped density } \\
(\mathrm{g} / \mathrm{ml})\end{array}$ & $\begin{array}{c}\text { Index of } \\
\text { compressibility }(\%)\end{array}$ & $\begin{array}{c}\text { Flowability } \\
(\mathrm{s} / 100 \mathrm{~g})\end{array}$ & LOD (\%) \\
\hline Formulation & & & & & \\
S1 & 0.500 & 0.617 & 18.96 & 9.8 & 1.97 \\
S2 & 0.442 & 0.549 & 19.48 & 11.5 & 3.10 \\
S3 & 0.515 & 0.602 & 14.45 & 11.9 & 2.65 \\
S4 & 0.388 & 0.481 & 19.33 & 10.9 & 2.49 \\
S5 & 0.543 & 0.658 & 17.48 & 11.9 & 3.30 \\
\hline
\end{tabular}

Table 3. Process control of disintegration time of film coated tablets

\begin{tabular}{lccccc}
\hline & \multicolumn{5}{c}{ Formulation } \\
\cline { 2 - 6 } Disintegration time (sec.) & $\mathrm{S} 1$ & $\mathrm{~S} 2$ & $\mathrm{~S} 3$ & $\mathrm{~S} 4$ & $\mathrm{~S} 5$ \\
& 180 & 360 & 150 & 145 & 160 \\
\hline
\end{tabular}

Table 4. Composition of examined formulations

\begin{tabular}{|c|c|c|c|c|c|}
\hline \multirow{2}{*}{ Excipient } & \multicolumn{5}{|c|}{ Formulation } \\
\hline & S1 & S2 & S3 & S4 & S5 \\
\hline Folic acid & $\mathrm{x}$ & $\mathrm{x}$ & $\mathrm{x}$ & $\mathrm{x}$ & $\mathrm{x}$ \\
\hline Lactose monohydrate & $\mathrm{x}$ & & $\mathrm{x}$ & $\mathrm{x}$ & $\mathrm{x}$ \\
\hline Microcrystalline cellulose & $\mathrm{x}$ & $\mathrm{x}$ & $\mathrm{x}$ & $\mathrm{x}$ & $\mathrm{x}$ \\
\hline Dicalcium phosphate & & $\mathrm{x}$ & & & \\
\hline Silicon dioxide & $\mathrm{x}$ & & & & \\
\hline Sodium lauryl sulphate & & $\mathrm{x}$ & $\mathrm{x}$ & & $\mathrm{x}$ \\
\hline Disintegration agent & & $\mathrm{x}$ & $\mathrm{x}$ & $\mathrm{x}$ & $\mathrm{x}$ \\
\hline Binder agent & & $\mathrm{x}$ & $\mathrm{x}$ & $\mathrm{x}$ & $\mathrm{x}$ \\
\hline Lubricant & $\mathrm{x}$ & $\mathrm{x}$ & $\mathrm{x}$ & $\mathrm{x}$ & $\mathrm{x}$ \\
\hline Film coat $/ \mathrm{mg} /$ & $\mathrm{x}$ & $\mathrm{x}$ & $\mathrm{x}$ & $\mathrm{x}$ & $\mathrm{x}$ \\
\hline Total mass $/ \mathrm{mg} /$ & 115 & 115 & 115 & 115 & 115 \\
\hline Preparing technique & $\begin{array}{l}\text { dry } \\
\text { mixing }\end{array}$ & dry mixing & $\begin{array}{l}\text { dry } \\
\text { mixing }\end{array}$ & wet granulation & $\begin{array}{c}\text { wet } \\
\text { granulation }\end{array}$ \\
\hline
\end{tabular}




\section{Dissolution}

Orally administered tablets have their drugs dissolved in the gastrointestinal tract fluids before the absorption can occur. Often, the drug absorption rate is determined by the drug dissolution from the tablets (The United States Pharmacopeia Convention., 2010) Therefore the dissolution rate had shown influenced to the efficacy of the tablet products so it's bioavailability at all (EMA, 2006).

The most direct assessment of the drug's release would be in vivo bioavailability tests. However, there are several reasons that restrict the use of in vivo studies: length of time required, low precision of the measurements, correlation with the diseased state might have to be made with healthy human subjects or with animals, est. Because of above mentioned facts in vitro studies were used in this research.
The composition of five different formulations, using various fillers and excipients, applied in different ratios and prepared by two different technological procedures are presented in Table 4.

Dissolution rate of five different formulations are presented in Table 5 and Fig 2.

All the tested products didn't met requirements of Folic acid dissolution rate. The dissolution range was $47.50-$ $99.87 \%$. It is obvious that partial solubility was obtained in compositions of formulation S1 and S2. In formulation S1, a combination of hydrophilic and hydrophobic filler was used prepared by dry mixing. However, the dissolution rate did not fulfill the requirements. In order to improve the dissolution rate, another filler (dicalcium phosphate) in combination with wetting agent, prepared by same technolog-

Table 5. Dissolution rate (\%) of folic acid (in single entity folic acid film-coated tablets ) in distillated water

\begin{tabular}{|c|c|c|c|c|c|c|}
\hline \multicolumn{7}{|c|}{ Formulation } \\
\hline \multirow[t]{2}{*}{ No. } & & $\mathrm{S} 1$ & $\mathrm{~S} 2$ & S3 & S4 & S5 \\
\hline & & \multicolumn{5}{|c|}{ Percent released in $45 \mathrm{~min}$ of single six tablets } \\
\hline \multicolumn{2}{|l|}{1.} & 51.84 & 68.18 & 84.49 & 92.31 & 99.84 \\
\hline \multicolumn{2}{|l|}{2.} & 60.35 & 76.90 & 84.28 & 94.57 & 97.54 \\
\hline \multicolumn{2}{|l|}{3.} & 59.49 & 77.72 & 86.77 & 93.56 & 95.30 \\
\hline \multicolumn{2}{|l|}{4.} & 51.18 & 65.14 & 88.16 & 92.55 & 96.90 \\
\hline \multicolumn{2}{|l|}{5.} & 53.70 & 75.82 & 84.31 & 93.13 & 97.20 \\
\hline \multicolumn{2}{|l|}{6.} & 47.46 & 53.18 & 84.24 & 87.92 & 98.30 \\
\hline \multicolumn{7}{|c|}{ Decsriptive statistics } \\
\hline \multirow{4}{*}{$\mathrm{n}=6$} & Min. & 47.46 & 53.08 & 84.24 & 87.92 & 95.30 \\
\hline & Max. & 60.35 & 77.72 & 88.06 & 94.57 & 99.84 \\
\hline & Average & 53.97 & 67.56 & 85.55 & 92.06 & 97.52 \\
\hline & STDEV & 5.111 & 10.175 & 1.650 & 2.514 & 1.647 \\
\hline
\end{tabular}

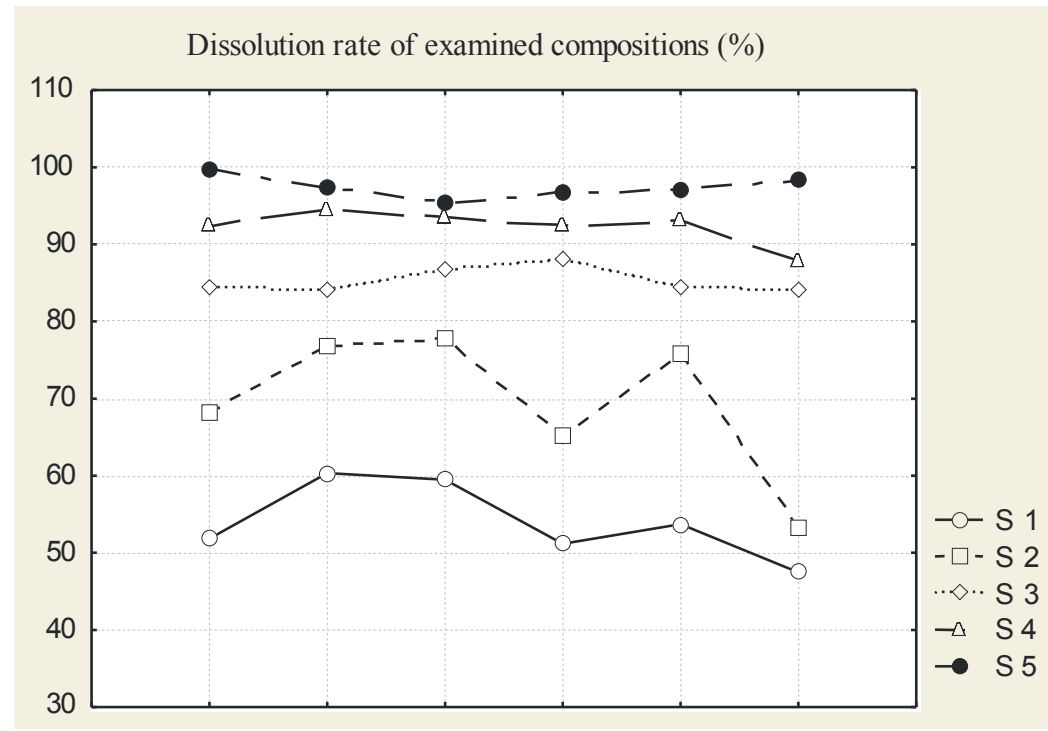

Fig. 2. Dissolution rate of folic acid in film-coated tablets in examined compositions 
ical procedure as in case of S1 formulation was used. This approach did not turn satisfying results, again (Table 5). Therefore in formulation S3, dry mixing was used in combination with fillers (the same from formulation S1) and wetting agent (the same from formulation S2). It is obvious that the chosen combination was plausible in terms increasing the dissolution rate (Table 5). In formulation S4 and S5 dry mixing has been changed by wet high shear mixing technique and at least $90 \%$ dissolution was achieved (The United States Pharmacopeial Convention, 2010). The obtained dissolution rates of both formulations were within prescribed specification. The only difference between the formulations S4 and S5 is the percentage ratio of chosen combination of fillers. In S4 formulation hydrophilic/hydrophobic filler ratio was $1: 1$, while S5 formulation the same ratio was set to $2: 1$. The differences in the formulations are correlating with the observed differences in the dissolution rate of the active substance (Table 2, Fig. 2)

\section{Conclusion}

Poor dissolution of commercially available folic acid preparations in simulated gastric fluids could significantly affect product efficacy. In order to increase the dissolution rate several compositions of formulations by two granulation techniques were examined. The optimal formulation which released average of $97.52 \%$ of active substance was formulated by combination of hydrophilic and hydrophobic filler in ratio $2: 1$ and addition of $1.0 \%(\mathrm{w} / \mathrm{w})$ wetting agent by wet high shear mixing.

\section{References}

Amiji, M.A., Sandman, B.J., 2003. Applied physical pharmacy, McGraw-Hill, Medical Pub. Division, New York, pp.166.

Du, J., Hoag, S.W., 2003. Characterisation of excipient and tableting factors that influence folic acid dissolution, friability,and brakiong strenth of ioil and water soluble multivitamin with mineral tablets. Drug Dev.Ind. Pharm. 29, 1137-1147.

European Pharmacopeia Commission 7.1, 2010.Monograph 0067

EMEA, 2006. Guideline of the investigation of bioequivalence Do.Ref.CMCP/EWP/QWP/1401/98Rev.1 /Corr** chp.4.2.1.App I

Hoag, S.W., Ramachandruni, H., Shangraw, R.F., 1997. Failure of prescription prenatal vitamin products to meet USP standards for folic acid dissolution. J. Am. Pharm. Assoc. (Wash.) NS37, 397-400.

Liberman, H.A., Lachman, L., 1981. Pharmaceutical dosage forms. Characterization of granulates, Marcel Dekker., New York, pp. 255.

Sculthorpe. N.F., Davies. B., Ashton. T., Allison. S., McGuire. D.N., Malhi. J.S., 2001. Commercially available folic acid supplements and their compliance with the British Pharmacopoeia test for dissolution. J. Public Health Med. 23, 195-197.

Stout, P.J., Brun, J., Kesner, J., Glover, D., Stamatakis, M., 1996. Performance assessment of vitamin supplements: efficacy issues. Pharm. Res. 13, S-71.

Suitor, C.W., Bailey, L.B., 2000. Dietary folate equivalents: interpretation and application. J. Am. Diet. Assoc. 100, 8894.

The United States Pharmacopeial Convention, Inc., Rockville, MD USP 2010-2011. Folic Acid tablets.

The United States Pharmacopeial Convention, Inc., Rockville, MD USP 2010-2011, General Chapters: <711> Dissolution

The United States Pharmacopeial Convention, Inc., Rockville, MD USP 2010-2011, General Chapters: < 701> Disintegration

The United States Pharmacopeial Convention, Inc., Rockville, MD USP 2010-2011, General Chapters: <731> Loss on drying

The United States Pharmacopeial Convention, Inc., Rockville, MD USP 2010-2011, General Chapters: <616> Bulk density and tapped density of powders

The United States Pharmacopeial Convention, Inc., Rockville, MD USP 2010-2011, General Chapters: <776> Optical microscopy

Zheng, J., Wiley, J., 2009. Formulation and Analytical Development for Low-Dose Oral Drug Products. pp.40265. 
Резиме

\title{
Влијание на различни формулации и техники на гранулација на растворливост на Фолна киселина во Фолна киселина филм обложени таблети
}

\author{
Љиљана Крстеска*, Дејан Костовски, Ксенија Брзилова, Сузан М. Сејфулах, Соња \\ Угарковиќ
}

\author{
Развој и истражување, Алкалоид АД, Александар Македонски 12, 1000 Скопје
}

Клучни зборови: растворливост, таблети, витамини, фолна киселина

Витамин фолна киселина има добиено значително внимание поради улогата во намалување на ризикот од дефекти на невралната туба кај новороденчиња, и потенцијална улога во намалувањето на ризикот од кардиоваскуларни и психијатриски болести. Ние истражувавме композиции од 5 различни формулации во однос на исполнувањето на USP стандарди за хемискот параметар растворливост и физичиот параметар распадливост на активна компонента. Сите испитани формулации одговараат на пропишанита спецификација на тестот за распаѓање, но само 3 формулации одговараат на спецификационите барања за растворливот т.е. ослободување на $75 \%$ од активната компонента за 45 минути . Максималната вредност на растволивост од $97,52 \%$ во формулацијата С 5 , беше постигната со комбинација на одредени ексципиенси (комбинација на хидрофилен и хидрофобен полнител и соодветно квасечко средство) и техника на влажна гранулација со мешалка со голема брзина, што резултира со оптимално ослободување на активната супстанца. 


\title{
Фалсификат на лекови
}

\author{
Арлинда Хаџиу ${ }^{*}$, Јасмина Тониќ - Рибарска², Сузана Трајковиќ - Јолевска \\ ${ }^{I}$ Фармација, Факултет за медицински науки ,” Државен унивезитет во Тетово “, Тетово, Македонија \\ ${ }^{2}$ Институт за применета хемија и фармацевтски анализи, Фармацевтски факултет, Универзитет ”Св. Кирил и \\ Методиј”, Скопје , Македонија
}

Received: April 2011; Accepted: July 2011

\begin{abstract}
Апстракт
Појавата на фалсификувани лекови е се почест растечки проблем и претставува општо јавно здравствена закана во светски рамки. Фалсификуваните лекови се разликуваат од сите останати производи по тоа што може да се штетни за пациентите/корисниците, а нивната употреба може да доведе и до фатални последици. Проценувајќ ја оваа проблематика како исклучително сериозна, Светската здравствена организација (World Health Organization, WHO) активно учествува во превземање на активности и мерки за справување со овој феномен. Според дефиницијата на WHO, фалсификувани лекови се производи што се ,намерно и лажно етикетирани во однос на идентитетот или изворот“. Според податоците на WHO се проценува дека $10 \%$ од лековите на светскиот пазар се фалсфикувани лекови. Меѓутоа, анализата на WHO покажала дека не е соодветно да се даде една единствена бројка за целиот свет, туку за проценка треба да се земат во предвид повеќе параметри во различните делови на светот. Во почетокот, фалсификуваните лекови се третирале како проблем на земјите во развој, но во последните години проблемот се јавува и во развиените земји. Заклучено е дека проблемот со фалсификувани лекови се јавува подеднакво и во развиените и неразвиените земји. Генерално, појавата на фалсификувани лекови е најизразена во земјите со послабо законодавство, послаби регулаторни и контролни механизми.

Во овој труд е даден преглед на проблемот на фалсификувани лекови, идентификувани се факторите што придонесуват за појава на фалсификувани лекови,наведени се видови и типови на фалсификат и досегашните активности за справувување со овој глобален проблем.
\end{abstract}

Клучни зборови: фалсификат на лекови, субстандардни лекови, справување со фалсификувани лекови

\section{Фалсификат на лекови - појава и дефиниција}

Фалсификуваните лекови имаат долга историја. Во првиот век во Грција, Dioscorides прв ги има класифицирано лековите според терапевтската употреба, притоа предупредувајќи на опасноста од фалсификувани лекови и препорачувајќи нивна идентификација. Во 17 век зголемената побарувачка во Европа за хинин од перуанската кора, за третман на маларија, претставувала потик да се прават фалсификати, особено затоа што овие лекови не биле регулирани. Меѓу првите регистрирани случаи на фалсификувани лекови е случајот од 1937 год., кога повеќе од 105 пациенти од Америка починале по употреба на еликсир Sulfonamide што

\footnotetext{
*arlindahaxhiu@gmail.com
}

содржал опасен растворувач диетилен гликол (Wax, 1995). Зголемувањето на бројот на фалсификувани лекови резултирал со губење на довербата на пациентите (Bahjat, 2008). Иако фалсификуваните лекови како феномен се јавуват одамна, нивната појава како проблем за прв пат се спомнува на Конференцијата за рационална употреба на лекови на Светска Здравствена Организација (World Health Organization, WHO) одржана во 1985 год. во Најроби, Кенија (Report of the Conference of Experts, 1985). Од тогаш започнува и развојот на јавната свест за проблемот на фалсификувани лекови, при што како еднакво загрижувачки го идентификуваат како надлежните органи, така и производителите на лекови.

Не постои една единствена глобална дефиниција за тоа што е фалсификуван лек. Токму поради оваа причина и различните земји имаат различно толкување, 
како и различен пристап кон фалсификуваните лекови. Ова може да доведе до недоразбирања во идентификацијата на проблемот, несоодветен пристап при неговото решавање, како и тешкотии во размената на информации.

Некои земји имаат различни дефиници за фалсификувани лекови, а во некои и не постои прифатена дефиниција. Повеќето земји на Европската унија ја имаат прифатено дефиницијата на WHO за фалсификувани лекови (WHO, 1992).

WHO го дефинира фалсификуваниот лек како:

Намерно погрешно обележување (етикетирање) на готови лекови или состојки (што се користат за нивно производство) во однос на идентитетот, составот или потеклото. Може да се фалсификуваат и заштитни (in-patent) и генерички производи.

Фалсификуваниот лек може да биде :

а) без активна супстанца

б) со активна супстаниа, но во недоволна количи$\mathrm{Ha}$

в) со погрешни состојки

г) пакуван во лажна амбалажа

Кога се зборува за фалсификувани лекови многу често не е доволно јасно што се подразбира под фалсификуван лек, а што е субстандарден лек.Затоа е многу важно да се направи разлика помеѓу фалсификувани лекови и субстандардни лекови (Табела 1) (WHO, 2003).

Супстандардните лекови може да се сметат за фалсификат ако се произведени намерно и иницијативно. Сите фалсификувани лекови се субстандардни додека сите субстандардни лекови не се фалсификат.

Меѓутоа последиците од фалсификуван лек и субстандарден лек се слични (Gren, 2009):

- директна штета за пациентот,терапевтски неуспех,

- слабее довербата на јавноста во здравствениот систем,

- негативно влијание врз угледот на дистрибутивниот ланец на лекови,

- предизвикуваат економска штета.

\section{Типови на фалсификати на лекови}

Познати се два типа на фалсификати на лекови (Harper, 2006):

- $\quad$ фалсификати на готовиот производ , и

- фалсификати на активната компонента ( API active pharmaceutical ingredients)

Постојат неколку начини на фалсификување на готовиот производ и тоа:

- идентична копија со идентична амбалажа и формулација

- чист фалсификат: о со друга активна супстанца и слично пакување;

○ без активна супстанца или

○ погрешно количество на активна супстанца

- лажно/нелегално обележување/амбалажа производите се лажно пакувани како да се од оригиналниот производител

- нелегално етикетирање и препакување на лековите

- $\quad$ нелегална дистрибуција и трговија на лековите преку интернет и други канали

- непакувани лекови, на пример лекови на кои им недостасува примарното пакување

- ставање на пазар на нерегистрирани лекови

- лажна документација

- отпад/интермедиери што во облик на препакуван производ со фалсификувана етикета се појавува во пазарот

- $\quad$ комбинација на фалсификат, на пример реетикетирање со погрешна доза на автентичен производ во пакувањето, производ фалсификуван за да се прекрие датумот/рокот на употреба или производи во фалсификувани амбалажи со цел да се имитира амбалажата на паралелните увозници

Најчести типови на фалсификат на активната компонента се:

- употреба на евтини активни компоненти со непознато потекло или произведени во усло-

Табела 1. Разлики помеѓу фалсификуван лек и субстандарден лек

\section{Фалсификуван лек}

Производител (вистинскиот идентитет/извор) непознати

Производителот вклучен во криминални активности

Сите фалсификувани лекови се субстандардни

\section{Субстандарден лек}

\author{
Произведени од познат (легитимен) \\ производител
}

Се јавуваат поради нестандарден, невалидиран производствен процес

Сите субстандардни лекови не се фалсификат 
ви кои не одговарат на Добра производствена пракса

- у употреба на активни компоненти што се произведени од нерегистрирани производители или производители што немаат одобрение за производство на активна супстанца

- $\quad$ активната супстанца не се произведува според регистрираниот процес; производителот поседува дупликатен систем на документација: еден за скриениот процес на производство на активна компонента и друг со лажен датум што одговара на GMP и служи за прикажување на фармацевтските инспекциски органи

- нерегистрирана активна компонента со непознато потекло се препокрива со име на активна компонента која е регистрирана.

\section{Видови фалсификувани лекови}

Според извештајот од истражувањето за фалсификувани лекови спроведено од страна на Советот на Европа, сите видови лекови може да бидат фалсификувани во зависност од особините на лекот како и од природата на пазарот (Harper, 2006). Сепак овој извештај покажува дека најчесто се фалсификуваат: лековите што најчесто се препишуваат, лекови со висока цена, познат бренд, генерички производи, парентерални препарати (во развиените земји); како и специфични лекови и терапевтски групи во зависност од степенот на развој на земјата:

- $\quad$ во развиените земји - познати брендови, препарати за третман на дисфункција на ерекцијата, за слабеење, и за намалување на холестеролот (на пример: Procrit, Viagra, Cialis, Reductil, Epogen, Neupogen, Lipitor, Lescor)

- во земјите во развој - антибиотици, анти-маларици, вакцини и лекови за третман на сида

Според овој извештај, иако лековите за еректилна дисфункција (Viagra) продолжуваат да бидат најпопуларни фалсификувани лекови во последните години, исто така многу се фалсификуваат и лековите за третман на сериозни болести како што се лековите за третман на зголемен холестерол, за остеопороза и хипертензија. Националната асоцијација на комори на САД (National Association of Boards of Pharmacy, NABP) има подготвено „Специфична национална листа на сомнителни лекови” што е достапна на http://www.nabp.net/ ftpfiles/NABP01/List.pdf. Со оваа листа се опфатени 32 лека што најчесто се фалсификуваат и претставуваат ризик за јавното здравје. Според ова листа тешко е да се определи кои специфични профили на лекови имаат поголема веројатност да бидат фалсификувани. Заеднички критериум е дека тоа може да се лекови со висока цена или лекови со голема потрошувачка.

\section{Последици од фалсификувани лекови}

Последиците од фалсификувани лекови може да се разгледаат од два аспекта: последици за здравјето на пациентите /јавното здравство и последици за фармацевтските компани

Примарната и најтешка последица од употребата на фалсификувани лекови е за здравјето на пациентите,бидејќи овие лекови:

- $\quad$ не обезбедуват ефикасен третман - најчесто се појавува кога фалсификуваниот лек содржи недоволно количество на активна супстанца или има несоодветни компоненти,погрешни количества на помошни супстанци.

- предизвикуват директна штета односно токсичен ефект - токсичните супстанци во лекот може да предизвикат невообичаени симптоми кои би можеле да ја отежнат дијагнозата и ефективноста на третманот, а во некои случаи да доведат и до фатален исход.

- $\quad$ може да бидат причина за појава на отпорност кон лековите - обично се јавува кај фалсификувани лекови наменети за третирање на болести предизвикани од бактерии,паразити и други микроорганизми.

Опасноста и можниот смртен исход од употреба фалсификувани лекови ќе го илустрираме преку неколку најдраматични евидентирани и потврдени случаи:

Случај 1 Во Хаити,Нигерија,Бангладеш и Аргентина во деведесетите години над 500 луѓе, повеќето деца, починале од ренална инсуфициенција по употреба на сируп за кашлање кој бил фалсификуван со антифриз (Walt, 2008)

Случај 2 Во Нигерија, 1995год. во текот на епидемија на менингит од фалсификувани вакцини умреле околу 2500 пациенти (Morris, 2006)

Случај 3 Во Аргентина, 2004 год. е евидентиран смртен случај на 22 годишна пациентка како последица на откажување на функцијата на хепарот,по примена на фалсификуван препарат на железо (Yectafer®,Astra Zeneca), во облик на инјекции,што наместо активна супстанца железо сорбитол соджел дериват на железо во повисока концентрација (IMPACT brochure, 2008)

Случај 4 Во Панама 2006год. повеќе од 100 пациенти починале од фалсификуван сируп за кашлање кој содржал диетилен гликол (Walt, 2008)

Производството на фалсификат на лекови е профитабилен бизнис бидејќи за нивно производство се користат евтини супстанци, се произведуваат во услови што најчесто не ги задоволуваат пропишаните стан- 
дарди (GMP), производниот процес не се валидира, нема трошоци за :

- контрола на квалитетот и утврдување на безбедноста и ефикасноста на лекот,

- регистрација, маркетинг, и др.

Ако се зема предвид фактот дека 10\% од лековите на светскиот пазар се фалсификувани, разбирливо е зошто фармацевтските компани се загрижени и вложуват толку напор и пари во современи методи за заштита на своите производи. Освен директните губитоци што ги имаат фармацевтските компании поради фалсификување на нивните производи, тие имаат и индиректни губитоци затоа што се губи реномето на компанијата и довербата на пациентите во лековите. Тоа од своја страна води до намалување на прометот на одредениот лек, што повторно доведува до финансиски губитоци за компанијата. Затоа многу компании избегнуваат да даваат податоци за фалсификување на нивните производи. Се смета дека една од причините за ваквото однесување е и јаката конкуренција, бидејќи конкурентот често може да ги користи податоците за фалсификуваниот лек на одредениот производител, како комерцијална предност (негативна пропаганда), особено кога истиот лек неколку пати се појавува како фалсификат. Освен компаниите, загуби поради фалсификувани лекови трпат и државите како последица на неплаќање на даноците и царинските давачки за сите оние фалсификувани лекови што се дистрибуираат низ нелегалниот дистрибутивен ланец.

\section{Фалсификат на лекови - растечки проблем}

Не постои ефикасен метод за одредување на нивото на појавата на фалсификувани лекови. Повеќето податоци се од извештаи на невладини организации, фармацевтски компании, национални регулаторни тела, ad-hoc студии на специфични/одредени географски области или терапевтски групи и повремени извештаи/анкети на национално, европско или меѓународно ниво. WHO добива извештаи за фалсификувани лекови од осумдесетите години, но само од земјите што се јавуват како волонтери за пријавување на овие случаи. Според овие податоци со оваа појава се опфатени и развиените земји и земјите во развој. Ниту една земја не е имуна на појавата на фалсификувани лекови. Во периодот 1982 - 1999 год., WНО има добиено 771 доверливи извештаи за фалсификувани лекови од различни делови од светот (WHO counterfeit drug database, 1999), а во периодот 1999 - 2000 год., 46 доверливи извештаи за фалсификувани лекови од 20 земји. Околу $60 \%$ од овие извештаи биле од развиените земји и $40 \%$ од земјите во развој (WHO - General information on counterfeit medicines).

Различни земји имаат различни видови фалсификувани лекови. Во Африка и азиските земји со низок стандард, најчесто фалсификувани лекови се антибиотици, антималарици, антитуберкулостатици и аналгетици, додека во земјите со висок стандард, како што е САД и западните европски земји најчесто како фалсификат се среќаваат имуносупресори, лекови за срцеви заболувања, таканаречени lifestyle drugs (лекови за подобрување на животот), како што се Viagra, хормони и стероиди (на пример: хуманиот хормон за раст што се употребува од страна на боди билдерите). WHO проценува дека фалсификуваните лекови се движат од помалку од $1 \%$ во развиените земји до повеќе од $30 \%$ во некои земји во развој. Така на пример во развиените земји со ефикасен регулаторен систем (САД, ЕУ, Австралија, Канада, Јапонија, Нов Зеланд) фалсификуваните лекови опфаќат 1\% од пазарната вредност. Голем број на земјите во развој во Африка, делови од Латинска Америка и делови на Азија се области каде што фалсификуваните лекови се над $30 \%$ од лековите во продажба. Во многу земји на бившиот Советски Сојуз процентот на фалсификувани лекови е над 20\% од пазарната вредност. Лековите набавени преку интернет што ја кријат вистинската физичка адреса опфаќаат околу 50\% на случаи на фалсификувани лекови (WHO -General information on counterfeit medicines). На Интернационалната конференција на WHO за справување со фалсификувани лекови одржана 2006 год., е изнесен податокот дека во периодот 2001 - 2005 год. се откриени 27 случаи на фалсификувани лекови во легалниот дистрибутивен ланец на EU, што е застрашувачки податок. Според Институтот за фармацевтска безбедност (Pharmaceutical Security Institute, PSI), непрофитно здружение што се занимава со заштита на јавното здравје, забележано е рапидно зголемување на случаите на фалсификувани лекови. Порастот на случаите на фалсификувани лекови за периодот 2002 - 2010 год. е прикажан на слика 1 .

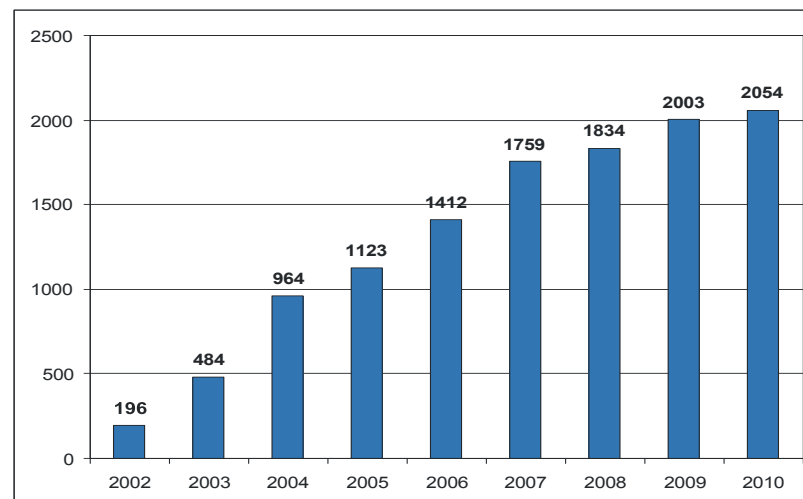

Слика 1. Вкупен број на инциденти за период 2002 2009 год.

(Извор: PSI)

Анализата на податоците од 2010 год. направена од страна на PSI (PSI,Geographic distribution) покажува 
дека од 2054 пријавени случаи на фалсификувани лекови од седумте региони во светот,Азија и Латинска Америка се на врвот на листата на региони каде најчесто има инциденти на фалсификувани лекови (слика 2).

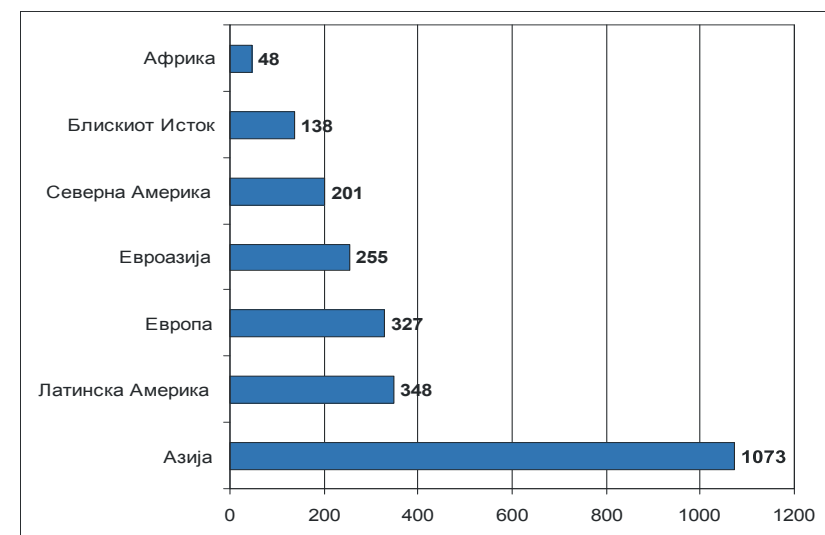

Слика 2. Број на инциденти со фалсификувани лекови по региони

(Извор: PSI)

Поголем дел на фалсификувани лекови во светот се со потекло од Азија, каде што производството на субстандардни и фалсификувани лекови е голем проблем. Според проценката на FDA во некои делови на Азија фалсификуваните лекови опфаќаат $50 \%$ од лековите во продажба што убиваат неколку илјади луѓе секоја година (Paul, 2009). Кина и Индија се сметаат за центар на производство на фалсфикувани лекови, потоа следуваат Југоисточна Азија, Русија, Мексико, Бразил и Латинска Америка (ACSH, Counterfeit drugs, 2009). Според статистичките податоци на WHO, во Индија се произведуваат околу $1 / 3$ од фалсификувани лекови во светот, што се совпаѓа со податокот објавен 2008 година од страна на Организација за економска соработка и развој (Organization for Economic Cooperation and Development, OECD) дека 75\% на фалсфикувани лекови во светот имаат потекло од Индија (Lal, 2008). Појавата на фалсификувани лекови покажува зголемување дури и во добро контролираните пазари, како Велика Британија (MHRA - Drug Alerts), САД (со 50 регистрирани случаи на фалсификувани лекови во дистрибутивниот ланец) (IMPACT brochure, 2008) и лекови набавени преку интернет (FDA, News Release, 2007) и Холандија (IMPACT brochure, 2008).

Во 2008 год. цариниците на Европската Унија на аеродромот на Брисел заплениле 2,2 милиони фалсификувани таблети, што претставува најголемо запленување на илегални лекови во Европа. Меѓу фалсификуваните лекови најмногу биле лекови против болки, маларија, рак, еректилна дисфункција, псеудоефедрин, антибиотици и лекови за намалување на холестеролот во крвта.Многу е важно да се потенцира фактот дека запленувањето на овие фалсификувани лекови е резултат на операцијата Меди фејк (Medi - Fake), прва коордиинарана акција спроведена од страна на царинската контрола од 27 земји членки на Европската Унија (MEDIFAKE action, 2008). Сите изнесени податоци укажуват на сериозноста на распространетоста и интензитетот на појавата на фалсификувани лекови, како и на тоа дека фалсификуваните лекови прераснуват во глобален социјален и економски проблем.

\section{Фактори што го помагаат фалсификувањето на лекови}

Постојат бројни фактори што ја помагат појавата на фалсификувани лекови. Некои фактори се слични/ општи, а некои се разликуваат според региони, во зависност од социоекономскиот статус на земјата. WHO имаа идентификувано неколку фактори (WHO - factors encouraging counterfeiting of drugs):

1. слабости и непостоење на соодветна легислатива од областа на лековите

2. неефективна/недоволна соработка, нетранспарентна и недоволна размена на информации

3. недостаток на сознанија за проблематиката помеѓу здравствените работници и пациентите

4. цена на лекови и разликата во цени во однос на нивото на животниот стандард

5. трговија преку повеќе посредници

6. корупција и конфликт на интереси

Секоја земја треба да направи сеопфатна анализа на состојбата, да ги идентификува факторите што најмногу влијаат на појавата на фалсификувани лекови и да спроведе ефикасни мерки за отсранување. Со тоа ќе се намали можноста за појава на фалсификувани лекови.

\section{Препорачани мерки на WHO за справување со фалсификувани лекови}

Фалсификуваните лекови се глобален проблем. Со оглед на фактот што тоа е мулти - факторијален и мулти - димензионален проблем, за негово правилно решавање е неопходна истовремена и координирана акција од владите, националните агенции за лекови, фармацевтските производители, фармацевтите, пациентите, меѓународните организации.

WHO во 1999 година има објавено прирачник на мерки за справување со фалсификувани лекови (WHO - Guidelines for the development of measures to combat counterfeit medicines, 1999). Според овој прирачник предложените мерки за справување со фалсификувани лекови се однесуват на: 
(А) мерки што треба да ги превземат владите на поедини земји

На државно ниво секоја земја треба да подготви соодветна национална политика за лекови и спроведување на соодветна стратегија во справување со фалсификувани лекови во зависност од сопствената ситуација,финансиските и човечки ресурси.На пример, во Велика Британија во 2007год. Агенцијата за лекови на Велика Британија (Medicines and Healthcare Product Regulatory Agency, MHRA) ја има објавено првата стратегија за справување со фалсификувани лекови за периодот 2007 - 2010год (MHRA, Anti counterfeiting strategy, 2007-2010).

(Б) мерки што треба да ги превземат надлежните органи за лекови

Надлежните органи треба да обезбедат дека сите активности поврзани со лековите се спроведуваат во согласност со сеопфатната легислатива,активно да соработуваат со полицијата и царината,навремено да ја информираат јавноста и да вршат едукација на корисниците/пациентите од проблематиката на фалсификувани лекови.

\section{(B) мерки и активности на засегнатите страни}

Сите засегнати страни мора да се ангажират на активен однос кон проблематиката на фалсификувани лекови ( фармацевтки компани, увозниците, трговците на продажба на големо и мало, здравствените работници, пациентите, невладини организации).

\section{(Г) соработка на меѓународно ниво}

Успехот во справувањето со фалсификувани лекови ќе биде поголем доколку постои соработка на регионално и меѓународно ниво што вклучува: развивање заедничка стратегија, брза и навремена размена на информации, усогласување на мерките за заштита и спречување на ширењето на фалсификувани лекови.

\section{Досегашни активности за справување со фал- сификувани лекови}

Од осумдесетите години кога фалсификатите на лекови се идентифицирани како сериозен проблем во светот, се превземани бројни активности и иницијативи во спречување на оваа појава. WHO имаа превземено низа активности и мерки, како на регионално така и на глобално ниво. Тука меѓу другото спаѓаат :

Водичот за развој на мерки во справување со фалсификувани лекови (WHO -Guidelines for the development of measures to combat counterfeit medicines, 1999). Овој водич дава совети за мерките што треба да бидат превземени од страна на различните засегнати страни во борба против фалсификувани ле- кови. WHO исто така организира бројни тренинг програми за справување со фалсификувани лекови, дава подршка за национална проценка на степенот на фалсификувани лекови, подршка за зајакнување на капацитетот на откривање и за едукација на населението.

Cистем за брзо информирање (Rapid Alert System, $R A S)$ - Регионалната канцеларија на WHO за земјите на Западен Пацифик во соработка со партнерските организации за заштита на јавното здравство, како дел од Стратегијата за подобрување на снабдувањето со есенцијални лекови во овој регион 2005-2010 год., иницирала воспоставување таканаречен RAS (RAS-combating counterfeit medicines), електронска комуникациска мрежа што вклучува претставници на држави и територии во регионот на WHO и на партнерските организации. Co RAS се пренесуваат информации за случаи на фалсификувани лекови со цел да се алармираат соодветните органи за превземање на навремени активности и мерки.

IMPACT - Со цел на зајакнување на свеста и превземање на акција против фалсификати на лекови, на Конференцијата во Рим, 2006 год, е формирана првата глобална иницијатива позната како Интернационална групација за борба против фалсификувани лекови (International Medical Products Anti-Counterfeiting Taskforce, IMPACT). На истата Конференција е усвоена и Римска Декларација. IMРАСТ на волонтерска основа ги вклучува сите 193 земји членки на WHO како и меѓународни организации, Национални агенци за лекови, регулаторни и законодавствени тела, асоцијации на производители и дистрибутери, здруженија на здравствени професионалци и пациенти. Мисијата на IMPACT е промовирање и зацврснување на интернационалната соработка во борбата против фалсификувани лекови.

Легислатива - Европскиот Парламент, во 2006 год. усвои Резолуција за фалсификувани лекови во која е наведена и дефиницијата за фалсификувани лекови на WHO, обемот на појавата на фалсификувани лекови во светот, со посебен акцент за итните мерки што треба да се превземат од страна на Европската Унија (EU) во справувањето со ова проблематика (European Parliament, Joint Motion for Resolution, 2009). Во февруари 2011, Европскиот Парламент го има усвоено предлог законот за фалсификувани лекови. Со овој закон се очекува значајно да се зголеми безбедноста на интегритетот на дистрибутивниот ланец во EU (European commission -legal framework, 2011).

Алатка за визуелна инспекиија на лекови - Во многу случаи фалсификуваните лекови се многу слични со оригиналниот производ. Меѓутоа како последица на лошото пакување, грешки во правописот на амбалажата, препечатување, некои фалсификувани лекови може да се идентифицират и со визуелна инспекција. Со цел да се олесни идентификацијата на сомнителните лекови со визуелна инспекција, Светското 
здружение на здравствени работници (World Healthcare Professions Alliance, WHPA) заедно со Американската фармакопеа (United States Pharmacopeia, USP Pharmacopeia) и Меѓународната фармацевтска федерација (International Pharmaceutical Federation, FIP) имаат подготвено “Алатка за визуелна инспекција на лекови “ (FIP,Tool for visual inspection of medicines.,2008) со што се олеснува идентификацијата на сомнителните лекови за понатамошно испитување . Листата е наменета за здравствените работници за препознавање на знаците на фалсификат преку неадекватно пакување, означување, и изглед на фармацевтскиот производ.Списокот е поделен во два дела:

- Дел за проверка на пакувањето (внатрешната и надворешна амбалажа, сигнатура, упатство за пациентот и слично), и

- Дел за проверка на физичките карактеристики на таблетите/капсулите (облик, големина, мирис, боја).

Во справувањето со фалсификувани лекови е многу битно вклучување и соработка на сите учесници во фармацевтскиот систем, бидејќи регулаторната рамка е само еден елемент за борба против фалсификувани лекови. Фалсификувањето на лекови е глобален предизвик и бара координирање на напорите на глобално ниво. Потребна е соработка на сите меѓународни партнери, главно преку WHO, во справувањето на ова проблематика, со цел да се заштитат пациентите од фалсификувани лекови. Токму за таа цел бројни организации преку своите активности и ангажмани активно учествуваат во оваа проблематика: Европски директорат за квалитет на лекови и здравствена заштита (European Directorate for the Quality of Medicines \& HealthCare, EDQM) , EFPIA, Меѓународното здружение на организации на пациенти (International Alliance of Patient's Organizations, IAPO), Европското здружение за генерични лекови (European Generic Medicines Association, EGA), Европското здружение на клиничките фармацевти (European Association of Hospital Pharmacists, EEAHР) и други.

\section{Заклучок}

Фалсификатите на лекови претставуваат сериозен општо глобален проблем .Земајќи ги во предвид податоците на случаите ширум светот и последиците од употребата на овие лекови може да се заклучи дека во справување со ова проблематика треба да се вклучат сите засегнати страни: надлежни регулаторни тела, полиција, фармацевтска индустрија, веледрогерии, здравствени работници, пациенти, невладини организации. Исто така секоја земја треба да развие сопствена национална стратегија за превенција и борба против фалсификувани лекови во зависност од состојбата и расположливите ресурси,со напоредно вклучување и потти- кнување на меѓународна соработка со цел сузбивање на овој проблем.

\section{Референци:}

American council on science and health-ACSH; 2009.Counterfeit Drugs - Coming to a pharmacy near you (http://www.acsh. org/docLib/20090202 counterfeitdrug09.pdf)

Bahjat, S., 2008. The counterfeit Medicine - A silent Epidemic. MEJFM 5(8), 16-17.

Brochure of IMPACT, 2008. Counterfeit drugs kill (http://www. who.int/impact/activities/en/

European Parliament, 2006. Joint Motion for a Resolution (http://www.europarl.europa.eu/sides/getDoc. do? pubRef=-//EP//NONSGML+MOTION+P6-RC-2006$0467+0+\mathrm{DOC}+\mathrm{PDF}+\mathrm{V} 0 / / \mathrm{EN}$

FDA, News Release: FDA Warns Consumers about Counterfeit drugs from Multiple Internet Sellers, May, 2007 (http://www.fda.gov/NewsEvents/Newsroom/ PressAnnouncements/2007/ucm108904.htm)

John, P., 2009. Supply Chain Management: Combating Counterfeits. Pharmacia; PharmaAsia (http://www. pharmaasia.com/article-7800-supplychainmanagementcom batingcounterfeits-Asia.html)

Lal, N., 2008. Fake drugs a bitter pill for India. Asia Times (http:// www.atimes.com/atimes/South_Asia/JF07Df01.html)

European commission.,2011.Legal framework. Legislation on falsified medicine (http://ec.europa.eu/health/human-use/ quality/fake-medicines/index_en.htm)

European Union , 2008.Customs: Millions of illegal medicines stopped by "MEDI-FAKE" action (http://europa.eu/rapid/ pressReleasesAction.do?reference $=$ IP $/ 08 / 1980 \&$ type $=$ HTM L\&aged $=0$ \&language $=$ EN\& guiLanguage $=e n$ )

MHRA -Drug Alerts issued relating to counterfeit medicines (http://www.mhra.gov.uk/Safetyinformation/Generalsafetyi nformationandadvice/Adviceandinformationforconsumers/ Counterfeitmedicinesanddevices/index.htm)

MHRA,2007-2010.Anti - Counterfeiting Strategy (http://www.mhra.gov.uk.Safetyinformation/ Generalsafetyinformationadvice/Adviceandinformationforc onsumers/Counterfeitmedicinesanddevices/CON019608)

Morris, J., Stevens, P., 2006. Counterfeit medicines in less developed countries, Problems and solutions. International Policy Network - London (http://www.fightingdiseases.org/ pdf/IPN Counterfeits.pdf)

Pfizer, Safeguarding the integrity of the medicines supply chain in Europe (http://wwwsafemedicines.org/resources/documents/ Pfizercftwo-pager.pdf)

PSI, 2011. Geographic distribution of counterfeit medicine (http:// www.psi-inc.org/geographicDistributions.cfm)

PSI , 2011.Incident Trends of counterfeit medicines (http://www. psi-inc.org/incidentTrends.cfm)

Walt, B., Hooker, J., 2008. From China to Panama, A trail of Poisoned Medicine. New York Times (www.nytimes. com/2007/05/06/world/06poison.html?)

Wax, M. P., 1995. Elixirs, Diluents, and the Passageof the 1938 Federal Food, Drug and Cosmetic Act. Ann. Intern. Med. 122, 456-461.

WHO, 1985. The rational use of Drugs the rational use of drugs. Report of the Conference of expert, Nairobi - Kenya

WHO, 1992.Counterfeit drugs. Report of joint WHO/IFMPA workshop. Geneva 
WHO,1999. Guidelines for the development of measures to combat counterfeit drugs, WHO/EDM/QSM/99.1 http:// www.who.int/medicines/publications/counterfeitguidelines/ en/index.html

WHO - Counterfeit medicines,Fact sheet No275, 2003 http:// www.who.int/mediacentre/factsheets/fs275/en

WHO, 2005. Rapid alert system on combating counterfeit medicines http://www.counterfeitmedalert.info/default2. asp?tag $=15$

WHO, Factors encouraging counterfeiting of drugs http://www.who. $\mathrm{int} /$ medicines/services/counterfeit/overview/en/index1.html

WHO -General information on counterfeit medicines http;//www. who.int/medicines/services/counterfeit overview/en/index1. html

\title{
Summary
}

\section{Counterfeit medicines}

\author{
Arlinda Haxhiu ${ }^{1 *}$, Jasmina Tonic - Ribarska², Suzana Trajkovic - Jolevska ${ }^{2}$ \\ ${ }^{1}$ Department of Pharmacy, Medical Sciences Faculty, "State University of Tetova”, Tetova, Macedonia \\ ${ }^{2}$ Institute of Applied Chemistry and Pharmaceutical Analysis, Faculty of Pharmacy, University "Ss Cyril and Methodius", \\ Skopje, Macedonia
}

Key words: counterfeit medicine, substandard drugs, combating counterfeit medicines

The occurrence of counterfeit medicines is a constantly growing problem which poses a serious threat to public health in the global. They distinguish from other products because they can harm patients and have fatal consequences. World Health Organization (WHO) assesses this as a serious problem and it take an active part in activities and steps in combating this phenomenon.

WHO defines counterfeit medicines as: "deliberately and fraudulently mislabeled with respect to identity and/or source ".

WHO estimated that counterfeit drugs account for more than $10 \%$ of the global medicines market. Recently those numbers have been updated, and now WHO states that is preferable not to refer to one number for the entire world, but rather to see the specific circumstances in the different parts of the world.Countefeit medicines have been perceived mainly as a problem for developing countries, but through the recent years counterfeit drugs have been found in the developed countries as well. According the data, the problem of counterfeit drugs is known to involve both developed and developing countries. But generally, problem of counterfeit medicines is much more serious in countries with lack legislation, regulatory gaps, weak enforcement and penal sanction.

In this paper is presented an overview on the problem of counterfeit medicines, were identifying the factors that are contributing on this problem, were specify types of counterfeit medicine and given overview of activities undertaken to combat this worldwide problem. 


\title{
Трипс договорот и фармацевтските пронајдоци
}

\author{
Катерина Анчевска Нетковска* \\ Фармацевтски факултет, Универзитет „Св. Кирил и Методиј“, Водњанска 17, 1000 Скопје, Македонија
}

Received: May 2011; Accepted: June 2011

\begin{abstract}
Апстракт
Постоењето на современа, модерна правна регулатива во одреден сегмент на националниот правен систем, како што е правното уредување на правата на интелектуалната сопственост е претпоставка, но не и гаранција за постоењето на ефикасна заштита на овие права. Договорот за трговските аспекти на правата на интелектуална сопственост - ТРИПС е еден од најзначајните документи кои се однесуваат на трговијата на правата од интелектуална сопственост. Овој договор е еден од најзначајните акти за хармонизација и имплементација на правата од интелектуална сопственост на мултинационално рамниште, преку кој интелектуална сопственост добива една нова димензија - светска глобализација на ова поле, кој го промовираат и развојот на технологијата.

Медицинската технологија е област во којашто е направен огромен напредок кој што не засега сите нас. Да се најде оптимум во заштитата на интелектуалната сопственост помеѓу краткотрајните интереси во максималниот пристап и долгорочните интереси во промоцијата на креативноста и иноваторството не е секогаш лесно. Обидувајќи се истото да се пренесе на интернационално ниво е дури уште потешко отколку во национални, домашни услови. Можеби најинтересно и највозбудлива област на дејствување се сигурно фармацевтските пронајдоци каде што тензијата помеѓу потребата да се одреди насочувачот за истражување и развој кај новите лекови и потребата од овозможување на поголема достапност на веќе постоечките лекови.

Прифаќањето на ТРИПС договорот значи пат за воспоставување правна и економска соработка со земјите од Европската Унија и сите останати земји.

Меѓународните стандарди ја обврзуваат Република Македонија континуирано да врши усогласување на нашето право со меѓународните конвенции на планот со правата на интелектуалната сопственост.
\end{abstract}

Клучни зборови: интелектуална сопственост, ТРИПС, фармацевтски пронајдоци, патенти

\section{1. Вовед}

Потребата од перманентното усовршување на механизмите за поефикасна заштита на правата од интелектуална сопственост, секако дека се наметна како еден од позначајните фактори при регулирање на оваа материја и тоа пред сѐ поради развојот на новите софистицирани технологии кои служат за создавање на нови интелектуални креации и користење на истите за сѐ побрзиот развој на меѓународната трговија на стоки и услуги во кои се инкорпорирани голем број на интелектуални права (Дабовиќ-Анастасовска, 2001). Националните закони во областа на правата на интелектуал-

\footnotetext{
*kaan@ff.ukim.edu.mk
}

ната сопственост можат да бидат многу модерни, хармонизирани на регионално и светско ниво-меѓутоа ова не е единствена претпоставка за заштита на правата од интелектуалната сопственост (Дабовиќ-Анастасовска, 2001). Прифаќањето на меѓународните договори како основен инструмент во спроведувањето на правото на индустриска сопственост и имплементирање во сопственото позитивно право е уште еден чекор во стандардизацијата на нашето право со правото на Европската Унија (Аќимовска-Поленак и сор., 2000).

Согласно ТРИПС ${ }^{1}$ Договорот, заштитата на инте-

\footnotetext{
${ }^{1}$ Уругвајската рунда одржана на 15.12.1993 год. е назив за мултилатералните трговски преговори што се водени во рамките на Општатаспогодба за трговија и гарините (GATT). Овие преговори резултираа со Спогодбата за основање на Светската трговска организа-
} 
лектуалната сопственост треба да допринесе за промоција на технолошките иновации и трансфер на технологијата со заеднички предности за корисниците и производителите на технолошките знаења и на начин спроводлив за социјален и економски успех и благосостојба, а засновани врз темелите на правото и законите. ТРИПС Договорот не преставува само обичен договор, преку кој ќе се максимизира степенот на заштита на интелектуалната сопственост, туку од него уште повеќе ќе излезе во преден план, оригиналноста на процесот на усогласувањето.

\section{2. Патентибилност на фармацевтските пронај- доци согласно ТРИПС Договорот}

Главното правило за патентибилноста е дека патентите треба да бидат достапни за секој пронајдок, без разлика дали станува збор за процес или материја, во сите полиња на технологијата без исклучок, каде што за сите пронајдоци ќе важат стандардни правила и критериуми за патентибилност, а тоа се: да преставуваат новина, да содржат во себе пронајдок и да се индустриски применливи. Исто така, патентниот пронаоѓач треба да ги искористи придобивките од соодветната иновација и на најдобар можен начин да ја проследи, да го спроведе понатака. Новиот дел на иновација, е клучниот момент на договарање за придобивките од патентната содржина, сѐ додека на стане јавно достапна важната техничка информација која можеби е од значајна корист во други технологии и сфери. За време на патентната заштита, а и по истекување на рокот, иновацијата навистина станува од интерес за јавноста зошто другите ги имаат неопходните информации за нејзиното ефектуирање.

Очекувањата за дозволеноста на патентибилноста, гледано низ призма на здравството може да се класифицира во три групи:

ција WTO). во Април, 1994, во Маракеч. Во рамките на Уругвајската рунда, меѓу другото е дискутирано за правата на интелектуална сопственост. Заклучокот од овие преговори инкорпориран во Анексот на WTO е донесување Договор за трговски аспекти на правата на интелектуална сопственост (ТРИПС-Договорот).Спогодбата на Светската трговска организација (WTO) и ТРИПС- Договорот стапија на сила на 1ви Јануари, 1995 година. Претходната спогодба резултираше со основање на нова и постојана институција- Светска Трговска организација.

На земјите членки на WTO им беше даден одреден временски период пред да започнат со примена на ТРИПС-Договорот. Оврска за примена на договорот настанува:

- $\quad$ на 1ви Јануари, 1996 година, односно една година по стапувањето на сила на Договорот на WTO;

- на 1ви Јануари, 2000 година, односно четири години по стапувањето на сила на Договорот за земјите во развој и за земјите во постапка на премин од средно планирано стопанство во пазарно стопанство

- 10 години од почетокот на примената на Договорот за најмалку развиените земји при што нема да се бара примена на поголемиот дел на одредбите на Договорот.
- Заштита за иновациите кои може да бидат економски злоупотребени, и со кои може да се повреди јавниот морал, вклучувајќи ја и заштитата на животинскиот и растителниот свет и здравје;

- Заштита на дијагностичките, терапевтските и хируршките методи за тертман на луѓе и животни;

- Заштита на животински и растителн пронајдоци.

Минимум права за патентите, според ТРИПС Договорот се содржани скоро во сите закони кои ја регулираат оваа материја, нагласувајќи ги правата на носителите на патентите и нивната заштита од недозволено користење и злоупотреба на патентираните методи, нивно имитирање, продавање и слично.

Според ТРИПС, дозволениот рок за заштита на патентите не може да биде покус од 20 години, од денот на поднесување на патентната пријава. Меѓутоа, важно е да се напомене дека и ако се јави потреба од продолжување на овој рок кај фармацевтските пронајдоци заради сложеноста, специфичноста и траењето на нивната регистрација ${ }^{2}$ ТРИПС не предвидува продолжување на рокот заради ваквите обврски. ${ }^{3}$ Заради тоа, многу од земјите во развој воведоа систем со кој ќе се продолжи периодот на заштита најмалку за време кое што е потребно дури од истиот произлезат релевантни ефекти дополнителна патентна заштита.

\section{3. Значење на ТРИПС Договорот и фармацевт- ските пронајдоци}

Ако го разгледуваме значењето на ТРИПС Договорот во однос на фармацевтските пронајдоци, најголем придонес има таму каде што патентната заштита треба да биде проширена врз новите подрачја како што е фармацевтското, агрохемиското и подрачјето за пијалоци и храна. Исто така важни економски ефекти можат да произлезат од обврската да се прошири времето на заштита, на 20 години од пријавувањето, особено за фармацевтските производи. Бидејќи, патентната заштита во фармацијата преставува приоритетна задача. за фармацевтските патенти ќе се менува зависно од неколку фактори:

- должината на транзициониот период кој се применува кај секоја земја членка поединечно

- датата на признавање и постоење на екслузивните маркетиншки права

- условите според кои патентите се признаени со особено расположивоста на присилни ли-

\footnotetext{
2 Постапка за пуштање на лек во промет.

${ }^{3}$ Ефективниот период за патентна заштита на хемиските пронајдоци и многу помала од 20 години, затоа што најголемиот дел од тој период ќе истече пред да се видат пазарните придобивки од истиот.
} 
ценци и начинот на кој законот за конкуренција се применува

- делот од пазарот за патентираните производи, еластичноста на нивните цени, применливоста на производите, разликите помеѓу структурата на пазарот пред и после ТРИПС Договорот, постоење на контрола на цените како и значењето на локалното производство на фармацевти, големината и технологијата на домашните фирми и др.

Исто така важно е како се применуваат транзициониот период и признавањето на екслкузивните права на пазарот. Зголемениот период за патентна заштита и јачината на екслузивните прзава го ограничуваат имитирањето од страна на домашните фирми. Заради тоа кога пронајдокот ќе стане јавно добро, технологијата веќе ќе биде заменета со некоја понова заштитена технологија. Меѓутоа и домашните пронаоѓачи ќе добијат подолг период во кој ќе можат да го покријат својот инвестиционен проект, иако овој износ нормално ќе биде понизок во земјите во развој.

Недостигот на емпиријата секако дека ќе ги намали економските ефекти на патентните одредби кои се различни зависно од општиот став на истражувачите. Гледано од еден полош агол, доаѓ до зголемување на плаќањето на правото на странските пронаоѓачи, соодветни загуби во инвестираните можности во домашните истражувања и развој, до повисоки цени на производите кои се предмет на монополското право за потрошувачите и до поголема зависност на увозот воопшто.

Од посветлата страна, заради универзалните патентни стандарди ќе има повеќе и подобри патентни пронајдоци во светот и дека тоа ќе ја стимулира економската активност дури и во оние земји кои сметаат само на неколку пробивања во покус или среден временски период. Исто така, слободното превземање на странската технологија може да ја ослаби домашната индустрија и да има тенденција на зависност, на пример домашната фармацевтската индустрија од странските вложувања во истражување и развој (Дуковски, 2000).

За да се реализираат и имплементираат целите од ТРИПС Договорот поврзани со стандардите на патентната заштита од областа на фармацијата треба да се согледаат следниве аспекти:

- Заедно со други 25 законски текста ТРИПС преставува интегрален дел на Договорот за основање на Светската Трговска Организација, и како таков има важна улога;

- ТРИПС ги покрива не само патентите туки и останатите области од правата на интелектуална сопственост;

- се заснова не само на минимум стандарди за заштита на интелектуалната сопственост, туку ја опфаќа и процедурата и потсетува дека заштитата треба да е достапна и да се ефектуира за сите носители на правата од интелектуална сопственост.

\section{4. Фармацевтски пронајдоци}

Кога пронајдокот се применува во областа на лековите, важат посебни услови, кои произлегуваат од одредбата на Европската конвенција за патенти, каде се вели дека „пронајдокот на метод на лечење на човечкото или животинското тело со операција или терапија, или пак на метод на дијагноза коишто се применуваат на човечкото или животинското тело не се смета дека може да се примени индустриски“ (С. 4 (2), ПА 1977; Чл. 52 (4), ЕКП), а пак индустриската примена е еден од условите за патентирање. Меѓутоа, јасно е наведено дека тоа не спречува една супстанција или состав да може да се примени индустриски, едноставно поради тоа што е пронајдена за употреба во кој било таков метод (С. 4 (3), ПА 1977; Чл. 52 (4), втора реченица, ЕКП).

Новите соединенија коишто се употребуваат како лекови можат да се патентираат сами по себе во сите земји коишто ја спровеле ТРИПС (Чл. 27.1, ТРИПС).

\section{1. Хемиски пронајдоции}

Постојат различни категории на пронајдоци во областа на хемијата; на пример, нови соединенија, нови состави, нови процеси на производство и нови употреби. Во наједноставниот случај се работи за ново хемиско соединение со позната структура, синтетизирано во истражувачка лабараторија. Едно ново соединение не може да биде пронајдок подобен за патентирање доколку не е индустриски применливо. Можеби стотици илјади нови соединенија се создаваат во универзитетските лаборатории, но најголемиот дел од нив се од користат за теоријата. За да може едно соединение да се патентира, не е доволно тоа да се користи за разрешување на некој проблем во механизамот на реакција или да има интересен спектар за апсорпција на ултравиолетови зраци, меѓутоа, ако на пример втората карактеристика укаже дека соединението би било корисно како стабилизатор на УВ кај пластика, тогаш тоа би можело да се патентира.

Соединенијата можат да се патентираат дури и ако се употребуваат само како посредници во подготовката на други соединенија. Според правилото, ако крајните производи се индустриски применливи, истото важи и за посредниците, и тоа не само за директниот претходник на финалниот производ, туку и за производите од претходните чекори во низата реакции. Затоа, тие посредници можат да се патентираат ако ги исполнуваат другите критериуми на новитет и неоочигледност.

Се разбира, обично пронајдокот не се состои од едно соединение, туку опфаќа група соединенија коишто имаат одредени заеднички структурни каракте- 
ристики и иста крајна употреба. Пронаоѓачот во истражувачката лабораторија ќе има задача да синтетизира доволно соединенија за да дознае кои соединенија ќе функционираат, а кои не, а пак застапникот за патенти ќе има задача во консултација со пронаоѓачот да одреди каков треба да биде опфатот на бараниот пронајдок, земајќи ги предвид наодите на пронаоѓачот, но и претходните сознанија.

\subsection{1.Очигледност}

Соединението може да биде ново и корисно, а да не може да се патентира бидејќи е толку слично со претходните сознанија, што при неговото создавање не е содржан никаков инвентивен чекор, или со други зборови тоа е очигледно. При проучувањето колку едно соединение е слично на некое соединение опишано во претходните сознанија, не треба да се проучат само структурните формули на соединенијата, туку и самите соединенија заедно со нивните својства. ${ }^{4}$

Не постои општ услов дека пронајдокот мора да биде подобар од претходниот за да може да се патентира. Некогаш, се бара пронајдокот да покажува „,технички напредок“, но тоа барање сега е укинато. Тешко дека големото подобрување на својствата може да биде доказ за присуство на инвентивен чекор, ако поради сличноста со претходните сознанија постои соменение за тоа.

Постои голема несигурност во ситуациите кога новото соединение со слична структура на претходните сознанија има подобри својства, од коишто некои можат да се предвидат, а некои не. Од друга страна, може да се тврди дека непредвидливите предности даваат можност за патентирање; тоа што одредени предности можеле да се предвидат, подготвувањето на новото соединение било очигледно и тогаш утврдувањето на другите предности е само откривање на својствата на супстанца којашто не може да се патентира. ${ }^{5}$ Бидејќ иие биле објавени, стручното лице можело да ги создаде сличните комплекси без инвентивен обид, а поттик за тоа биле нивните предвидени подобри својства. Другото неочекувано својство коешто било пронајдено „не било значајно за издавањето на патент“.

\footnotetext{
${ }^{4}$ Така, да претпоставиме дека пронајдокот се состои од одредена група на бромирани ароматски соединија коишто се користат како редуктори на пламен, а најсличното претходно сознание е соединение коешто би спаднало во истиот опфат, освен што е хлорирано наместо бромирано. Ако ова хлоро-соединение беше опишано во академска публикација каде што немаше да се препорача никаква употреба за него или ако тоа имаше поинаква употреба од онаа како редуктир на пламен, тогаш пронајдокот ќе требаше да се патентира и покрај многу големата структурна сличност, едноставно поради тоа што немаше да биде очигледно дека соединенијата на бромот би можеле да се користат како редуктори на пламен.

5 Техничкиот апелационен одбор во Европската служба за патенти постапи според вториот став кога се сметаше дека еден пронајдок во врска со сепулкрат комплекси е очигледен поради тоа што пронаоѓачот имал објавено слични комплекси
}

Може да се постави прашањето како ова се разликува од нормалната ситуација на пронајдок којшто е сличен на претходните сознанија; навистина може да се каже дека пронајдокот со селекција е нормална ситуација бидејќи сите класи на соединенија се веќе познати и во тој смисол секое ново соединение е селекција од некоја претходно претставена група, како што се „стероидите“ или „,азо- боите“.

\subsection{2 Пролекови и активни метаболити}

Утврдено е дека кога фармаколошки активно соединение се аплицира на човечкото или животинското тело, дел од соединението може да се излачи како непроменето, но наместо тоа, на дел од него или на целото соединение можат да настанат хемиски промени коишто резултираат во низа метаболити коишто понатаму се излачуваат или разграничуваат. Често се случува еден или повеќе метаболити исто така да бидат активни и не е невообичаено да се утври дека активноста на соединението коешто се аплицира целосно се должи на активниот метаболит. Ако се знае дека едно соединение е фармаколошки активно, тоа се смета за лек, а соединението коешто самото по себе не е активно, но кое се хидролизира или метаболизира на друг начин во телото, за да го формира активниот лек се смета за „пролек”. Ако активноста на соединението се должи на фактот што тоа е метаболизирано од друго соединение, дали соединенијата поврзани на овој начин се сметаат за пролек и лек или лек и активен метаболит е прашање на случајност.

Ако прво е измислена вистинската активна супстанца, соединението коешто е пронајдено по неа и метаболизирано од неа (пролек) може да има некаква фармаколошка предност (на пр. споро ослободување) или може да се смета едноставно како начин да се одбегне заштитата со патент (Bent, 2000).

\section{2 Природни производи}

Голем број на природни производи од растително и животинско потекло имаат корисни фармаколошки својства. Често слушаме дека природните производи не можат да се патентираат. Барањето за новооткриен природен производ може да биде валидно ако е составено така да прави разлика помеѓу производот за кој што се поднело барањето и производот којшто се наоѓa во природата. ${ }^{6}$ Така во еден дамнешен случај во САД беше одобрен патент за чист адреналин изолиран од ткивото на надбубрежната жлезда (Grubb, 1999; ParkeDavis против Mulford, 196 F. 496); чистата супстанца беше медицински корисна, додека пак суровиот екстракт од жлездата не беше. Во повеќето земји беа одо-

\footnotetext{
6 Ова на пример, може да се направи со поднесување на барање за чистата форма на производот или со дефинирање на физичките карактеристики коишто укажуваат на одреден степен на чистота.
} 
брени такви патенти за новоизолирани хормони, цитокини и други супстанци коишто постојат во човечкиот организам. Исто така треба да се потсетиме дека многу антибиотици се природни производи бидејќи тие првично биле изолирани од култури на габи коишто се наоѓаат во природата; никогаш немало сериозни проблеми за поднесување на барање за тие антибиотици како за нови соединенија. Навистина, можеби не е потребно да се вклучи ограничување на чистотата во барањето ако се толкува дека барањето не го опфаќа производот така како што е пронајден во природата. Ако производот во неговата природна состојба не претставува повреда на барањето, тогаш тоа не треба да биде ни неговата претпоставка.

Друг начин е да се употреби техниката за комбинаторна хемија со којашто стотици или илјадници различни соединенија можат истовремено да се синтетизираат со комбинирање на различни почетни материјали, чекори од реакција и реагенси, за да се создаде „библиотека” на соединенија коишто тогаш можат да се скенираат. Се разбира, не е логично да создаде обична смеса од сите соединенија заедно: за да се добијат логични резултати од скенирањето мора да може да се утврди кои соединенија се активни.

Интересен проблем е до кој степен може да се добие заштита на патент за библиотека на соединение коешто се разликува од групата соединенија содржани во библиотеката. Иако е познато кои структури ќе ја сочинуваат групата и постои можност да се направи генеричка формула којашто ги опфаќа, ако едноставно се поднесе барање за соединенијата, обично ќе претставува проблем тоа што некој од нив

\section{3 Комбинирани препарати}

За разлика од повеќето хемиски области каде што може да се патентираат едноставни смеси на познати соединенија ако се нови и ако може да се покаже инвентивниот чекор со одредено подобрено својство, практиката во областа на фармацијата во САД е многу построга; барањата за смесите од две или повеќе фармацевтски активни состојки секогаш се сметаат за очигледни на прв поглед и во принцип се одбиваат освен ако не може да се покаже дека постои синергија или „суперадитивен“ ефект.

Меѓутоа нема причина за построг приод кон патентирањето на смеси од фармацевтската област од на пример, оној во областа на детергентите. Секој може да пласира на пазарот детергент којшто се состои од смеса на состојки поединечно одобрени како сигурни за таква употреба. Од друга страна пак, никој не може да пласира на пазарот комбиниран производ од два стари лека, без да добие одобрение од националните регулаторни органи коешто во принцип нема да се даде, освен ако не се покаже дека комбинацијата има вистинска предност пред посебните компоненти. Меѓутоа компа- нија којашто ќе успее да ја убеди ФДА дека новиот производ има доволно предности за да се пласира на пазарот може да не успее да ја убеди Службата за патенти на САД дека има доволно предности за да се патентира но дури и да го стори тоа судовите можат да не се сложат (Grubb, 1999; Richardson - Vicks Inc против The Upjohn Co., 44 USPQ2d 1181 (сојуз. Цир. 1997). Многу тешко, а дури и невозможно, е да се докаже синергијата помеѓу двата лека, главно поради тоа што е практично невозможно да се предвиди што може да се очекува доколку не постои ефектот на синергија. Ова може да биде долга и тешка практика дури и за едноставна измерлива мерка како крвниот притисок; кога ефектот кој што треба да се мери е стапка на зачестеност на некоја ретка појава, како на пример, процентот на пациенти кои доживуваат срцеви напади во одредено време а посебно, пак, кога резултатите треба да се добијат од клинички студии на луѓе поради тоа што не постојат соодветни тестови за животни, тогаш станува практично невозможно да се докаже синергијата.

Ова не треба да значи дека тие состави не можат да се патентираат. Ако може да се покаже синергијата тогаш комбинацијата треба да може да се патентира, но дури и кога нема синергија треба да можат да се искористат и други подобри и неочигледни резултати за да се утврди присуството на инвентивен чекор. Да претпоставиме дека соединенијата А и Б го имаат истиот фармацевтски ефект при доза од 100 мг, но при таа доза и двете предизвикуваат одредени несакани странични појави; исто така да претпоставиме дека комбинацијата од 50 мг А и 50 мг Б го дава точно истиот посакуван ефект, но со редуцирани странични појави. Не постои доказ за синергијата помеѓу А и Б, но сепак предноста на помалите странични појави, ако се претпостави дека не можела да се предвиди, треба да биде доволна за да може да се патентира комбинацијата.

На пример, често е пожелно да се имаат мали но релативно стабилни концентрации на лек во телото во релативно долг временски период. ${ }^{7}$

\section{4 Прва фармацеевтска употреба}

При истражувањето може да се утврди дека соединението коешто било направено, тестирано и за кое е утврдено дека е корисно како лек претставува новитет. Тогаш не постои проблем за патентирање на самата супстанца (ако се претпостави дека не е очигледна). Меѓутоа, со истражувањето може да се открие дека супстанцата е веќе позната, на пример таа може да биде спомената во патент којшто повеќе не важи, а во којшто се опишани фотографски сензибилизатори, или пак може да биде дадена како пример во научен труд во

\footnotetext{
${ }^{7}$ На пример, замена за честото редовно голтање на таблети се лепенките од коишто лекот полека се апсорбира преку кожата или инјекции за складирање од ситни честички на биолошки распадлив полимер коишто го ослободуваат лекот во текот на недели или месеци.
} 
којшто не е откриена никаква употреба на соединението. И во двата случаи е исклучена заштитата на производот и треба да се најде друго решение.

Како што веќе беше споменато, една можност е да се поднесе општо барање за фармацевтските состави коишто ја содржат активната состојка. Предноста на тие барања е тоа што тие не се ограничени на одредена фармацевтска индикација; тие подеднакво би го опфаќале соединението во сируп против кашлица или во супозиториј за хемороид. Друг приод е да се поднесе барање за употребата на соединението како за лек. Тука треба да се надминат одредени проблеми поради тоа што употребата на супстанца како лек е еднаква на методот на медицински лечење којшто, како што видовме, е посебно исклучен од патентирање со ЕКП и Законот за патенти од 1977 година.

Меѓутоа и ЕКП и Законот за патенти од 1977 година содржат одредба во којашто се вели дека за „пронајдок којшто се состои од супстанца или состав за употреба во методот на лечење на човечкото или животинското тело со операција или терапија“, фактот што супстанцата или составот се стари не спречува пронајдокот да се смета за нов ако нема позната претходна фармацевтска употреба.

\section{5. Заклучок}

ТРИПС - договорот се смета и како договор со кој се хармонизира правото на конкуренција во светски рамки, и тоа во обем поголем од било кој друг во системот на Светската Трговска Организација, со што се покажува дека воведувањето на светското право на конкуренција ќе биде долг процес.

Отсекогаш постоела посебна врска помеѓу патентите и фармацевтските пронајдоци. Патентирањето на медицинските методи, односно методите за лечење со операција, терапија или со дијагностички методи отсекогаш било контроверзна тема според сите закони за патенти или пак предмет на различни судски практики.

Заштитата за пронајдокот којшто се состои од тоа што познато хемиско соединение може да се користи како лек, логично следи прашањето каква заштита со патент може да се добие за пронајдокот којшто се со- стои од тоа што соединението за коешто е веќе познато дека имало една или повеќе фармацевтски употреби, има нова фармацевтска намена којашто не е поврзана со ниедна претходна употреба.

Ако може да се добие патент за боење на најлон со средство за боење кое што претходно се користело за боење на волна и истите можат да се патентираат (под услов да се нови и неочигледни), зошто да не може да се направи тоа и со новите употреби на лековите?

Не постои суштинска причина зошто пронајдок од овој вид би можел помалку да се заштити со патент отколку некој друг. Работата која што е вложена за да се направи пронајдокот, потенцијалната корист за јавноста и потенцијалното комерцијално значење, можат да бидат исто толку големи како за пронаоѓаето на нов хемиски ентитет којшто има фармацевтска намена.

\section{Литература}

Аќимовска-Поленак, М., Анастасовска-Дабовиќ, Ј., Бучковски, В., 2000. Основи на правото на индустриска сопственост - Македонска ризница Куманово.

Bent, D., 2000. Pharmaceutical patents in Europe - Stockhlom

Дабовиќ-Анастасовска, J., 2001. Меѓународни станадарди обврска за поефикасна заштита на правата на интелектуална сопственост во РМ - Годишник на Правен факултет Скопје.

Дуковски, В., 2000. Влијание на ТРИПС Договорот врз стандардите кај прават на индустриската сопственост со посебен осврт на патентитте - Право и менаџмент на интелектуална сопственост

Европска Конвенција за патенти С. 4 (2), ПА 1977; Чл. 52(4), (http://www.epo.org/law-practice/legal-texts/html/epc/ 1973/e/ma1.html).

Европска Конвенција за патенти С. 4 (3), ПА 1977; Чл. 52 (4), втора реченица, (http://www.epo.org/law-practice/legal-texts/ html/epc/1973/e/ma1.html).

Grubb P.W., 1999.Patents for Chemicals Pharamceuticals and Biotechnology, Oxford University press Parke-Davis против HK Mulford, 196 F. 496

Grubb, P.W., 1999. Patents for Chemicals Pharamceuticals and Biotechnology, Oxford University press.

ТРИПС -договор Чл. 27.1, (http://www.wto.org/english/ tratop_e/trips_e/t_agm0_e.htm). 


\title{
Summary
}

\section{Trips Agreement and Pharmaceutical Inventions}

\author{
Katerina Ancevska Netkovska*
}

Faculty of Pharmacy, University of Ss Cyril and Methodius, Vodnjanska 17, 1000 Skopje, Macedonia

Key words: intellectual property, TRIPS, pharmaceutical inventions, patents

Existence of contemporary, modern legal regulations in a certain segment of the national legal system, such as legal regulation of intellectual property rights is an assumption, but not a guarantee for the presence of efficient protection of these rights. The Agreement on Trade-Related Aspects of Intellectual Property Rights-TRIPS is one of the most important documents related to the trade of intellectual property rights. This Agreement is one of the most important acts on harmonization and implementation of intellectual property rights at multinational level, whereby the intellectual property is assigned a new dimension-world globalization of this field, also promoted by technology development.

Medical technology is an area of huge progress of concern to all of us. Finding an optimum in intellectual property protection among short-term interests in the maximum approach and long-term interests in promoting creativity and innovation is not always easy. Trying to transfer that at international level is even harder than in national, domestic conditions. Maybe the most interesting and exciting field of activity is definitely that of pharmaceutical inventions, where tension exists between the need to determine the landmark for research and development of new pharmaceuticals and the need for allowing greater availability of the existing pharmaceuticals.

The acceptance of TRIPS Agreement means a way to establish legal and economic cooperation with European Union countries and all other countries.

International standards oblige Republic of Macedonia to continuously harmonize our law with international conventions in the field of intellectual property rights. 



\section{INSTRUCTIONS FOR AUTHORS}

Macedonian Pharmaceutical Bulletin is an official publication $\mathrm{f}$ the Macedonian Pharmaceutical Association. The journal publishes original scientific papers, short communications, reviews, mini-reviews and professional papers from all fields of pharmacy and corresponding scientific fields of interest for pharmacy (pharmaceutical and medicinal chemistry, immunology and imunochemistry, molecular biology, pharmaceutical analyses, drug quality control, pharmaceutical technology, pharmacoinformatics, pharmacoeconomics, biopharmacy, pharmacology, applied botany, pharmacognosy, toxicology, clinical pharmacy, food and nutrition, physical pharmacy, organical synthesis, social pharmacy, history of pharmacy etc.)

The Macedonian Pharmaceutical Bulletin, also, publishes and other contributions (recommendations and announcements, reports of meetings, important events and dates, book reviews, various rubrics).

\section{Types of paper}

Original scientific papers (full length manuscripts) should contain own unpublished results of completed original scientific research.

Short communications also should contain completed but briefly presented results of original scientific research. The article should be prepared as described for full length manuscripts, except for the following: the number of pages should not exceed 10 (including 2 illustrations, figures or tables). An Abstract should be included as well as a full reference list.

Reviews and mini-reviews are written at the invitation of the Editorial Board. "Mini-reviews" of a topic are especially welcome.

They should be surveys of the investigations and knowledge of several authors in a given research area, the competency of the authors of the reviews being assured by their own published results.

Professional papers report on useful practical results which are not original but help the results of the original scientific research to be adopted into practical use. Professional papers might be based on the elaborating of theoretical data

\section{Language}

Original scientific papers, short communications, reviews and mini-reviews should be written in good English (American or British usage is accepted, but not a mixture of these), while professional papers and all other contributions may be submitted in Macedonian.

\section{Submission declaration}

Submission of an article implies that the work described has not been published previously (except in the form of an abstract or as part of a published lecture or academic thesis), that it is not under consideration for publication elsewhere, that its publication is approved by all authors and tacitly or explicitly by the responsible authorities where the work was carried out, and that, if accepted, it will not be published elsewhere in the same form, in English or in any other language.

\section{Policy and ethics}

The work described in your article must have been carried out in accordance with The Code of Ethics of the World Medical Association (Declaration of Helsinki) for experiments involving humans http://www.wma.net/ en/30publications/10policies/b3/index.html;

EC Directive 86/609/EEC for animal experiments http:/ec.europa.eu/environment/chemicals/lab animals/ legislation en.htm;

Uniform Requirements for manuscripts submitted to Biomedical journals http://www.icmje.org. This must be stated at an appropriate point in the article.

\section{Submission}

Please submit the manuscript electronically (e-mail address: magl@ff.ukim.edu.mk) as a single PDF file, which will be used in the peer-review process. All correspondence, including notification of the Editor's decision and requests for revision, takes place by e-mail removing the need for a paper trail. 


\section{Referees}

Please submit, with the manuscript, the names, addresses and e-mail addresses of 3 potential referees. Note that the editor retains the sole right to decide whether or not the suggested reviewers are used.

Papers received by the Editorial Board are sent to referees. The suggestions/comments of the referees and Editorial Board are sent to the author(s) for further action. The revised article should be returned to the Editorial Board as soon as possible but in not more than 30 days.

\section{Preparation of manuscripts}

\section{Use of wordprocessing software}

It is important that the file be saved in the native format of the wordprocessor used. The text should be typed (1 $11 / 2$ spaced) on A4 paper with margins of $3.0 \mathrm{~cm}$ on each side in single-column format, font Times New Roman, Mac C Times, Macedonian Times and size 11, Keep the layout of the text as simple as possible. Most formatting codes will be removed and replaced on processing the article. In particular, do not use the wordprocessor's options to justify text or to hyphenate words. However, do use bold face, italics, subscripts, superscripts etc. When preparing tables, if you are using a table grid, use only one grid for each individual table and not a grid for each row. If no grid is used, use tabs, not spaces, to align columns. The electronic text should be prepared in a way very similar to that of conventional manuscripts. To avoid unnecessary errors you are strongly advised to use the "spell-check" and "grammarcheck" functions of your wordprocessor.

The pages in the article should be numbered.

Finally, please create PDF file before sending the article. After acceptance, you will be asked to supply the article as wordprocessing document (zip-file).

\section{Appendices}

If there is more than one appendix, they should be identified as A, B, etc. Formulae and equations in appendices should be given separate numbering: Eq. (A.1), Eq. (A.2), etc.; in a subsequent appendix, Eq. (B.1) and so on. Similarly for tables and figures: Table A.1; Fig. A.1, etc.

\section{Abbreviations}

Define abbreviations that are not standard in this field in a footnote to be placed on the first page of the article. Such abbreviations that are unavoidable in the abstract must be defined at their first mention there, as well as in the footnote. Ensure consistency of abbreviations throughout the article.

\section{Units}

Follow internationally accepted rules and conventions: use the international system of units (SI). If other units are mentioned, please give their equivalent in SI.

The names of substances should be in accordance with the IUPAC recommendations and rules or Chemical $A b$ stracts practice.

\section{Math formulae}

Present simple formulae in the line of normal text where possible and use the solidus (/) instead of a horizontal line for small fractional terms, e.g., X/Y. In principle, variables are to be presented in italics.

\section{Footnotes}

Footnotes should be used sparingly. Number them consecutively throughout the article, using superscript Arabic numbers. Many wordprocessors build footnotes into the text, and this feature may be used. Should this not be the case, indicate the position of footnotes in the text and present the footnotes themselves separately at the end of the article. Do not include footnotes in the Reference list.

\section{Table footnotes}

Indicate each footnote in a table with a superscript lowercase letter.

\section{Figures}

Figures (photographs, diagrams and sketches) and structural formulae should each be given on a separate sheet (the place to which they belong in the text should be indicated). The figures should be numbered in Arabic numerals (e.g. Fig. 1). Ensure that each illustration has a caption. Supply all captions separately, not attached to the figure. A caption should comprise a brief title (not on the figure itself) and a description of the illustration. Keep text in the illustrations themselves to a minimum but explain all symbols and abbreviations used.

Please submit the pictures in a black and white version.

Tables

The tables should be numbered in Arabic numerals (e.g. Table 1) and each should be given on a separate sheet (the place to which they belong in the text should be indicated). Number tables consecutively in accordance with their appearance in the text. Place footnotes to tables below the table body and indicate them with superscript lowercase letters. Be sparing in the use of tables and ensure that the data presented in the tables are not duplicated elsewhere in the article. 


\section{Article structure}

Manuscript should contain: title, abstract, key words, introduction, material and methods, results and discussion, conclusion, acknowledgment (if desired) references and summary.

\section{Subdivision}

Divide your article into clearly defined sections (Abstract, Introduction, Material and methods. etc.). Any section or subsection may be given a brief heading. Each heading should appear on its own separate line.

\section{Essential title page information}

Papers should be preceded by a title page comprising: the title, the complete name(s) of the authors, and the author's affiliations.

Title. Concise and informative. Avoid abbreviations and formulae where possible.

Author names and affiliations. Where the family name may be ambiguous (e.g., a double name), please indicate this clearly. Present the authors' affiliation addresses (where the actual work was done) below the names. Indicate all affiliations with a lower-case superscript letter immediately after the author's name and in front of the appropriate address. Provide the full postal address of each affiliation, including the country name of each author.

Corresponding author. Clearly indicate (with *) who will handle correspondence at all stages of refereeing and publication, also post-publication. Ensure that telephone and fax numbers (with country and area code) are provided in addition to the e-mail address and the complete postal address.

Each paper must begin with an Abstract which should not exceed more than 250 (original scientific and professional papers) or 100 (short communications) words. The abstract should state briefly the purpose of the research, the principal results and major conclusions. References should be avoided, but if essential, then cite the author(s) and year(s). Also, non-standard or uncommon abbreviations should be avoided, but if essential they must be defined at their first mention in the abstract itself. Immediately after the abstract, provide a list of 3 to 6 keywords arranged in the order according to their importance.

\section{Introduction}

State the objectives of the work and provide an adequate background, avoiding a detailed literature survey or a summary of the results.

\section{Material and methods}

Provide sufficient detail to allow the work to be repro- duced. Methods already published should be indicated by a reference: only relevant modifications should be described. Manuscripts which are related to theoretical studies, instead of Material and methods, should contain a sub-heading and the Theoretical background where the necessary details for verifying the results obtained should be stated.

\section{Results}

Results should be clear and concise.

\section{Discussion}

This should explore the significance of the results of the work, not repeat them. A combined Results and Discussion section is often appropriate. Avoid extensive citations and discussion of published literature.

\section{Conclusions}

The main conclusions of the study may be presented in a short Conclusions section, which may stand alone or form a subsection of a Discussion or Results and Discussion section.

\section{Acknowledgements}

Collate acknowledgements in a separate section at the end of the article before the references and do not, therefore, include them on the title page, as a footnote to the title or otherwise. List here those individuals who provided help during the research (e.g., providing language help, writing assistance or proof reading the article, etc.)

\section{References}

\section{Citation in text}

Please ensure that every reference cited in the text is also present in the reference list (and vice versa). Any references cited in the abstract must be given in full. Unpublished results and personal communications are not recommended in the reference list, but may be mentioned in the text. If these references are included in the reference list they should follow the standard reference style of the journal and should include a substitution of the publication date with either "Unpublished results" or "Personal communication". Citation of a reference as "in press" implies that the item has been accepted for publication and a copy of the title page of the relevant article must be submitted.

\section{Web references}

As a minimum, the full URL should be given and the date when the reference was last accessed. Any further information, if known (DOI, author names, dates, reference to a source publication, etc.), should also be given. Web references can be listed separately (e.g., after the reference list) under a different heading if desired, or can be included in the reference list. 


\section{Reference style}

Text: All citations in the text should refer to:

1. Single author: the author's name (without initials, unless there is ambiguity) and the year of publication;

2. Two authors: both authors' names and the year of publication;

3. Three or more authors: first author's name followed by "et al." and the year of publication.

Citations may be made directly (or parenthetically). Groups of references should be listed first alphabetically, then chronologically.

Examples: "as demonstrated (Allan, 1996a, 1996b, 1999; Allan and Jones, 1995). Kramer et al. (2000) have recently shown...."

List: References should be arranged first alphabetically and then further sorted chronologically if necessary. More than one reference from the same author(s) in the same year must be identified by the letters "a", "b", "c", etc., placed after the year of publication.

\section{Examples:}

Reference to a journal publication:

Van der Geer, J., Hanraads, J.A.J., Lupton, R.A., 2000. The art of writing a scientific article. J. Sci. Commun. 163, 51-59.

Reference to a book:

Strunk Jr., W., White, E.B., 1979. The Elements of Style, third ed. Macmillan, New York.

Reference to a chapter in an edited book:

Mettam, G.R., Adams, L.B., 1999. How to prepare an electronic version of your article, in: Jones, B.S., Smith, R.Z. (Eds.), Introduction to the Electronic Age. E-Publishing Inc., New York, pp. 281-304.

Journal abbreviations source

Journal names should be abbreviated according to

Index Medicus journal abbreviations: http://www.nlm. nih.gov/tsd/serials/lji.html

List of serial title word abbreviations: http://www.issn. org/2-22661-LTWA-online.php;

CAS (Chemical Abstracts Service): http://www.cas. org/sent.html.

Manuscripts written in English should contain a Summary in Macedonian at the end of the paper. The summary should contain: title, author(s) full-name(s), surname(s), author's affiliations (institution and address), key words and abstract. Professional papers written in Macedonian should contain a summary in English in which the same data should be included.

\section{Submission checklist}

It is hoped that this list will be useful during the final checking of an article prior to sending it to the journal's Editor for review. Please consult this Guide for Authors for further details of any item.

Ensure that the following items are present:

One Author designated as corresponding Author:
- E-mail address

- Telephone and fax numbers

- All necessary files have been uploaded

- Keywords

- All figure captions

- All tables (including title, description, footnotes)

- Further considerations: Manuscript has been "spellchecked" and "grammar-checked"

- $\quad$ References are in the correct format for this journal

- All references mentioned in the Reference list are cited in the text, and vice versa

- Permission has been obtained for use of copyrighted material from other sources (including the Web)

\section{After acceptance}

Proofs

One set of page proofs (as PDF files) will be sent by e-mail to the corresponding author. Please list the corrections and return them via e-mail. If, for any reason, this is not possible, then mark the corrections and any other comments on a printout of your proof and return by fax, or scan the pages and e-mail, or by post. Please use this proof only for checking the typesetting, editing, completeness and correctness of the text, tables and figures. Significant changes to the article as accepted for publication will not be accepted.

We will do everything possible to get your article published quickly and accurately. Therefore, it is important to ensure that all of your corrections are sent back to us in one communication: please check carefully before replying, as inclusion of any subsequent corrections cannot be guaranteed. Proofreading is solely your responsibility. Note that Macedonia Pharmaceutical Bulletin may proceed with the publication of your article if no response is received.

\section{Offprints}

The corresponding author, at no cost, will be provided with a PDF file of the article by e-mail. The PDF file is a watermarked version of the published article and includes a cover sheet with the journal cover image.

Additional paper offprints can also be ordered for an extra charge. 


\section{АЦЕРО人А ААКАЛОИАด}

таблети

3а џвакање

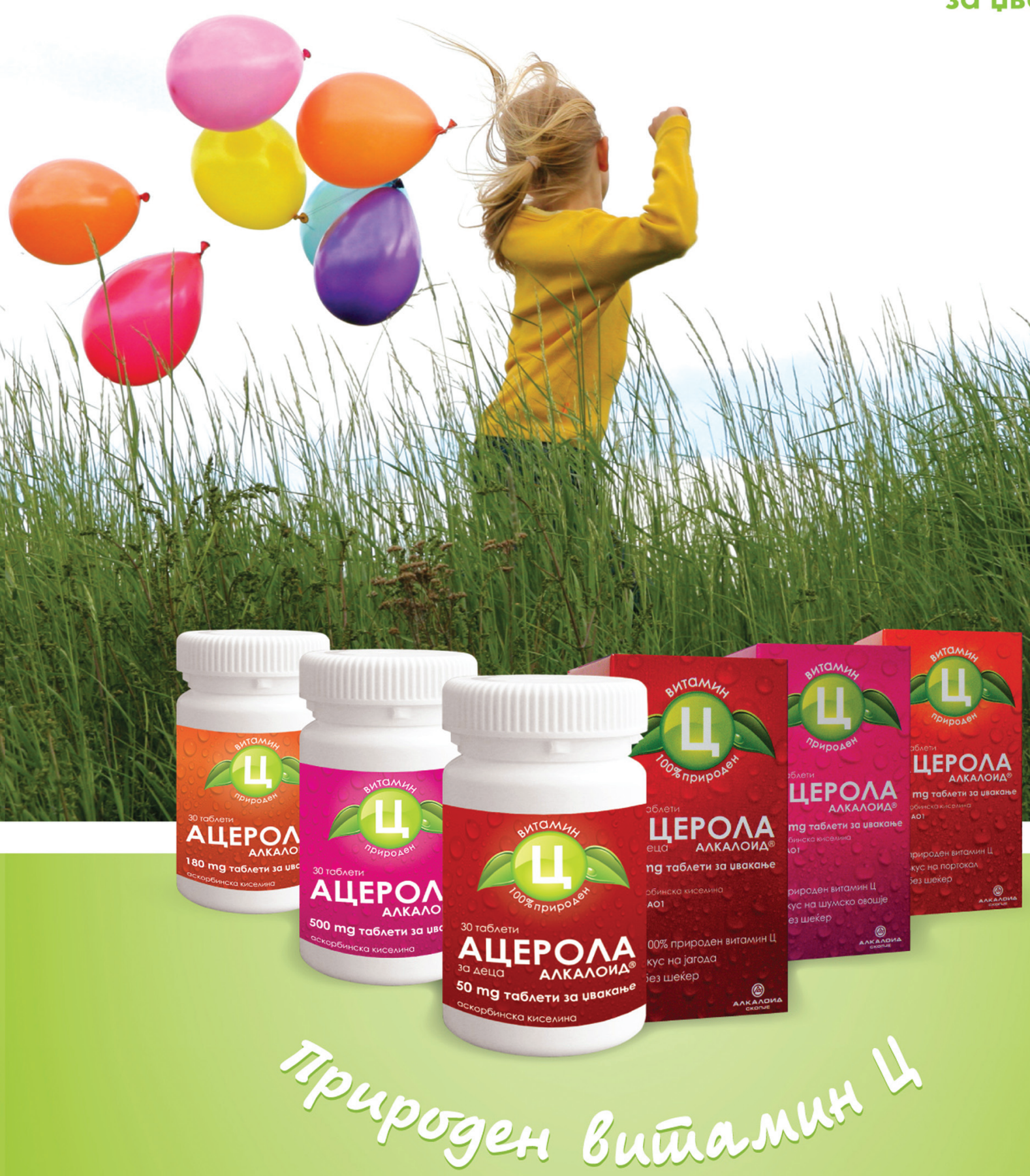

$\varnothing$ Единствен грироден извор на здразје

$\checkmark$ го јақне имулылетот

( Mоќн антиоксиданс

AAKAAOUA

$\nabla$ Без додаток на шекер 


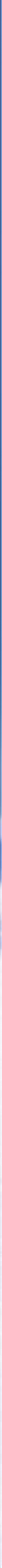

BRONCHO-VAXOM ${ }^{\circledR}$ - имуностимулас: C. Лиофилизиран лизат на бактерии: капсули од 7 мг (возрасни) и 3.5 мг (деца), 3.5 мг ќесички (деца). И. Имунотерапија. Превенција од рекурентни инфекции на дишните патишта и инфективни егзацербации на хроничен бронхитис. Комедикација при третманот на акутните инфекции на дишните патишта. Д. Третман на акутни епизоди: 1 капсула / на ден на празен стомак, во период од најмалку 10 дена. Превентивна и/или консолидирана терапија: 1 капсула / на ден од најмалку 10 дена месечно во период од 3 месеци. КИ. Хиперсензитивност на состојките на Broncho - Vaxom. П. Не се препорачува за деца помали од 6 месеци, поради недоволно развиениот имунолошки систем. Бременост и доење: сеуште не постојат контролирани клинички тестови. НЕ. Гастроинтестинални нарушувања (гадење, абдоминална болка, повраќње), кожни реакции (осип, уртикарија), респираторни потешкотии (кашлица, диспнеа, астма) и вообичаени потешкотии (треска, замор, алергиски реакции). Третманот треба да се прекине во случај на долготрајни гастроинтестинални нарушувања и кожни реакции или репираторни потешкотии (можни алергиски реакции). За подетални информации, обратете се до локалниот претставник на OM Pharma SA. 10 и 30 капсули или ќесички од 3.5 мг (деца), 10 и 30 капсули од 7 мг (возрасни). 
Andol 100

ацетилсалицилна киселина во пуфериран облик

ЗА ПРЕВЕНЦИЈА И ЛЕКУВАЊЕ НА КАРДИОВАСКУЛАРНИ ЗАБОЛУВАњА
Ando ${ }^{\oplus} 300$

ацетилсалицилна киселина од 300 mg во пуфериран облик
Брз и ефикасен при:

- зголемена температура (настинка и грип)

- главоболка

- забоболка мускули и зглобови

болка во ми повреди
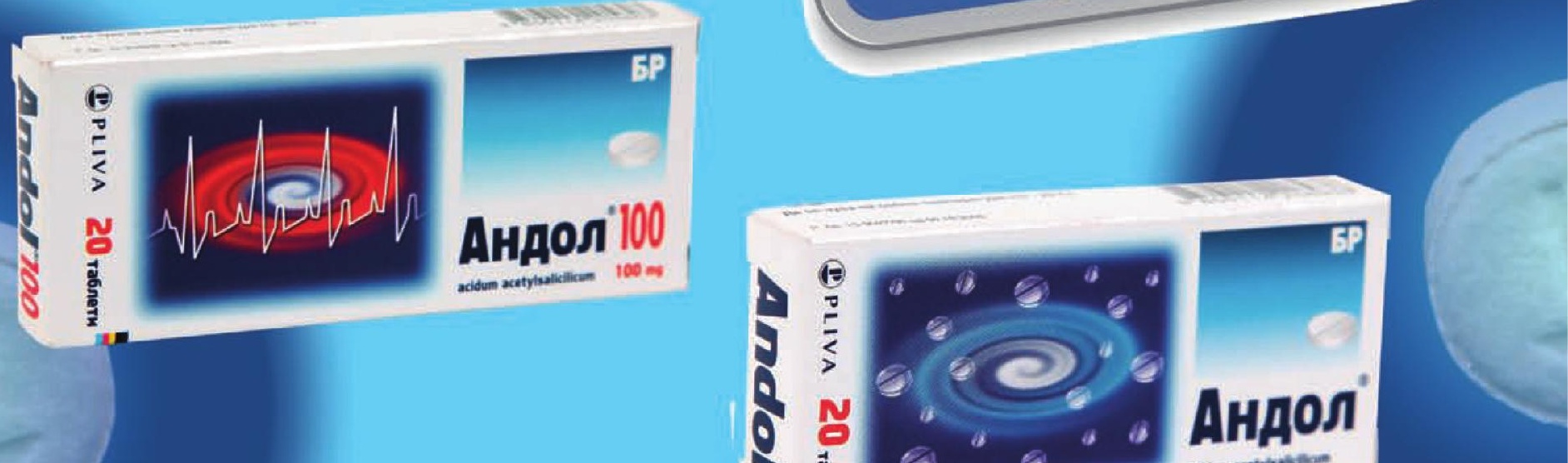
